\author{
UNIVERSIDADE DE SÃO PAULO \\ FACULDADE DE MEDICINA DE RIBEIRÃO PRETO \\ PÓS-GRADUAÇÃO EM IMUNOLOGIA BÁSICA E APLICADA
}

A ativação do receptor AIM2 na mucosa intestinal confere proteção ao diabetes tipo 1 experimental

Jefferson Antônio Leite

RIBEIRÃO PETO - SP 


\title{
A ativação do receptor AIM2 na mucosa intestinal confere proteção ao diabetes tipo 1 experimental
}

\author{
Jefferson Antônio Leite
}

\begin{abstract}
Dissertação apresentada ao Programa de PósGraduação em Imunologia Básica e Aplicada da Faculdade de Medicina de Ribeirão Preto da Universidade de São Paulo como parte das exigências para obtenção do título de Mestre em Ciências - Área: Imunologia Básica e Aplicada.
\end{abstract}

Orientadora: Prof. Drª . Daniela Carlos

Ribeirão Preto/SP

2.018 
Autorizo a divulgação total ou parcial deste trabalho, por qualquer meio convencional ou eletrônico para fins de estudo e pesquisa desde que citada a fonte

FICHA CATALOGRÁFICA

Leite, Jefferson Antônio

A ativação do receptor AIM2 na mucosa intestinal confere proteção ao diabetes tipo 1 experimental.

Ribeirão Preto, 2018, 113p.; 11; 30cm

Dissertação de mestrado apresentada à Faculdade de Medicina de Ribeirão Preto/USP. Área de concentração: Imunologia Básica e Aplicada

Orientador: Carlos, Daniela.

1. Diabetes tipo 1;2. AIM2; 3. Resposta imune inata; 4. Resposta imune adaptativa. 
Nome: Jefferson Antônio Leite

Título: A ativação do receptor AIM2 na mucosa intestinal confere proteção ao diabetes tipo 1 experimental

Dissertação apresentada ao Programa de PósGraduação em Imunologia Básica e Aplicada da Faculdade de Medicina de Ribeirão Preto da Universidade de São Paulo como parte das exigências para obtenção do título de Mestre em Ciências - Área: Imunologia Básica e Aplicada.

Aprovado em:

Banca examinadora:

Prof. Dr.

Instituição:

Julgamento:

Assinatura:

Prof. Dr.

Instituição:

Julgamento:

Assinatura:

Prof. Dr.

Julgamento:

Instituição:

Assinatura: 


\section{Dedicatória}

Aos meus pais Luzia e Arildo, meu irmão João Vitor, e a minha avó Inês. Obrigado por todo o amor incondicional e em momento algum cessarem em me apoiar durante essa etapa da minha vida. Dedico esta conquista com todo amor unicamente a vocês! 


\section{Agradecimentos}

Agradeço à Deus pela presença constante em minha vida e por sempre me fazer acreditar em sua grandeza e perfeição. À Jesus seu filho, pela graça e bondade, pela mansidão de coração, pelo exemplo a ser seguido. À nossa mãe Maria, por sua proteção e intercessão, que sempre me mostrou o melhor caminho a seguir.

Aos meus pais Luzia e Arildo, pelo amor, carinho, cuidado e pela fundamental educação que me proporcionaram. Obrigado por acreditarem e apoiar os meus sonhos. Ao meu irmão João Vitor, o qual tenho o maior orgulho de chamar de irmão. Obrigado por sempre me apoiar, e não cessar em ajudar para que eu chegasse até aqui. Tenho em você, a inspiração de um grande homem, de bom coração, e um grande pai de família. Agradeço a minha avó Inês e minha segunda mãe, Rose, pelo amor e apoio incondicional, e por todas as orações.

Ao meu melhor amigo Marley, que se tornou um anjinho, e lá do céu estás a me proteger. A certeza do seu amor e proteção foi fundamental para que eu chegasse até aqui. Obrigado por ter sido o melhor cãozinho do mundo, e ter me amado tão quanto eu te amei.

A Prof. Dra . Daniela Carlos, por ter me recebido em seu grupo, e ter compartilhado seus conhecimentos científicos e técnicos, aos quais me possibilitaram um grande crescimento profissional.

Ao Prof. Dr. João Santana da Silva, por ter me recebido em seu laboratório. Obrigado por todos os ensinamentos, e conhecimentos transmitidos. Considero-o um exemplo profissional a ser seguido. A ele os meus mais sinceros agradecimentos.

Aos meus grandes amigos, Bell, Tamara, Gabriela, Alynne, Franciele, Herculano e Ricardo, que tive a honra de conhecer nestes dois anos, assim como compartilhar de inúmeros momentos de felicidade e companheirismo. Obrigado pela amizade e apoio incondicional.

A todos os colegas do laboratório de Imunoparasitologia, pelas discussões cientificas e companheirismo na ciência. Meu muito obrigado.

Aos funcionários, Vera Aguile (Verinha), Cristiane Milanezi (Cris), Wander Ribeiro (Wanderzito), Denise Ferraz, Elizabete Rosa, Wendy, Isaíra (Isa) 
Rubilan, Edinelson e Júlio pela eficiência e carinho com que conduzem seus trabalhos, que possibilita a realização das nossas atividades do dia-a-dia.

A secretária do Programa de Pós-Graduação em Imunologia Básica e Aplicada, Ana Cristine, meu muito obrigado pelo acolhimento, amizade, e por sempre estar disposta à nos auxiliar e apoiar durante essa etapa de nossas vidas.

A Fundação de Amparo à Pesquisa do Estado de São Paulo (FAPESP) pelo financiamento e bolsa concedida (Processo no 16/25116-0). 


\section{APOIO E SUPORTE FINANCEIRO}

Este projeto foi desenvolvido no Laboratório de Imunoparasitologia, coordenado pelo Professor João Santana da Silva - Departamento de Bioquímica e Imunologia da Faculdade de Medicina de Ribeirão Preto - Universidade de São Paulo.

- Fundação de Amparo à pesquisa do Estado de São Paulo (FAPESP)Processos: 2012/10395-0 e 2016/25116-0. 
"Lembre-se de olhar para as estrelas, e não para baixo, para os seus pés. Tente achar sentido no que você vê e pergunte sobre o que faz o universo existir. Seja curioso. E por mais difícil que a vida possa parecer, há sempre algo que você pode fazer e ter sucesso. O mais importante, é que você não desista". 


\section{LISTA DE ESQUEMAS E FIGURAS}

Esquema 1- Mecanismos celulares e moleculares relacionados com 0 desenvolvimento do DM1;

Esquema 2- Mecanismos de ativação do complexo inflamassoma;

Figura 1- O receptor AIM2 é ativado nos LNP e íleo durante o DM1

Figura 2 - A deficiência de AIM2 confere suscetibilidade ao DM1;

Figura 3 - A ativação de AIM2 controla a disbiose intestinal e a translocação bacteriana para os LNP durante o DM1;

Figura 4 - A ativação do receptor AIM2 regula a expressão de proteínas de junção celular no epitélio intestinal;

Figura 5 - A ativação do receptor AIM2 regula à expressão gênica das citocinas IL-18, IL-22, defensinas, peptídeos antimicrobianos e mucinas no íleo;

Figura 6- O DNA de bactérias da microbiota em disbiose ativa o inflamassoma AIM2 in vitro;

Figura 7 - A ativação do receptor AIM2 por DNA fecal em disbiose aumenta a expansão de linfócitos Th17 derivados do LNM após reestimulo in vitro;

Figura 8 - O receptor AIM2 participa da diferenciação de linfócitos Th17;

Figura 9 - A ativação do receptor AIM2 regula a expressão de genes relacionados à resposta de linfócitos Th17 no íleo;

Figura 10 - A ativação do receptor AIM2 regula de forma positiva a resposta de linfócitos Th17 nos LNP e LNM;

Figura 11 - A ativação do receptor AIM2 não interfere na produção de IL-17 por células T CD8 nos LNP;

Figura 12 - A deficiência de AIM2 interfere na produção de citocinas do perfil Th17 no tecido intestinal e pancreático;

Figura 13 - A ativação de AIM2 é importante para a resposta de neutrófilos intestinais; 
Figura 14 - A ativação de AIM2 modula negativamente a reposta de linfócitos Th1;

Figura 15 - A ativação de AIM2 modula negativamente a reposta de linfócitos Tc1;

Figura 16 - A deficiência de AIM2 interfere na produção de citocinas do perfil Th1/Tc1 no tecido intestinal e pancreático;

Figura 17 - A deficiência de AIM2 regula a expressão dos receptores TLR4 e TLR9 em células dendríticas nos LNP durante o DM1. 


\section{LISTA DE ABREVIATURAS}

A

Abx - Antibióticos

APC - Células apresentadoras de antígeno

AIM2- Absent in melanoma 2

B

BMDM - Macrófagos derivados da medula óssea

C

CAD - Cetoacidose diabética

CARD - Domínio de recrutamento e ativação de caspase

CD - Cluster de diferenciação

Células NK - Células Natural Killer

D

DC - Célula dendrítica

DM1 - Diabetes mellitus tipo 1

DNA - Ácido desoxirribonucleico

DP - Desvio padrão E

EPM - Erro padrão da média

$\mathbf{F}$

FIIND - Domínio function to find G

GAD - Descarboxilase do ácido glutâmico

H

HLA - Antígeno leucocitário humano

I

IFN-y - Interferon gama

IL - Interleucina 
L

LNPs - Linfonodos pancreáticos

LPS - Lipopolissacarídeo

LRR - Repetições ricas em leucina

M

MHC-II - Complexo principal de histocompatibilidade - II

$\mathbf{N}$

NF-кB - Fator nuclear kB

NLR - Receptor NOD-like

NLRP1 - NLR family pyrin domain containing 1

NOD - Camundongo diabético não obeso

NOR - Camundongo resistente não obeso

$\mathbf{P}$

PAMPs - Padrões moleculares associados ao patógeno

PBMC - Células mononucleares de sangue periférico

PCR - Reação em cadeia da polimerase

PRR - Receptores de reconhecimento de padrões

PYD - Domínio pyrin

$\mathbf{R}$

RNA - Ácido ribonucleico

S

sgRNA - Short-guide RNA

SNP - Polimorfismo de nucleotídeo único

STZ - Estreptozotocina

$\mathbf{T}$

Th - Célula T helper

TLR - Receptor Toll-like

TNF- $\alpha$ - Fator de necrose tumoral alfa 
WT - Wild type 


\section{SUMÁRIO}

$\begin{array}{ll}\text { Lista de esquemas e figuras } & 10\end{array}$

Lista de abreviaturas $\quad 12$

1 Introdução 21

1.1 Aspectos gerais sobre o Diabetes Mellitus tipo 1...................... 22

1.2 Mecanismos desencadeadores da autoimunidade no DM1......... 23

1.3 Modelos experimentais para o estudo do DM1 .......................... 26

1.4 Receptores NLRs e ALRs: Ativação e formação do complexo 27 inflamassoma

1.5 Evidências da ativação de inflamassomas na autoimunidade....... 29

1.6 Envolvimento da microbiota intestinal no DM1....................... 31

1.7 Permeabilidade intestinal: Conceitos e correlações com $0 \quad 32$ desenvolvimento do DM1

1.8 Importância dos linfócitos Th17 na mucosa intestinal................... 33

2. Objetivos 36

$2.1 \quad$ Objetivos gerais......................................................... 37

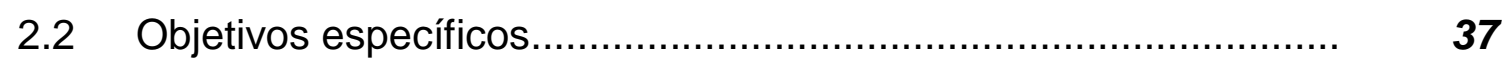

3. Materiais e métodos 38

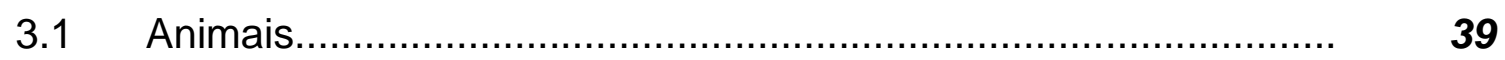

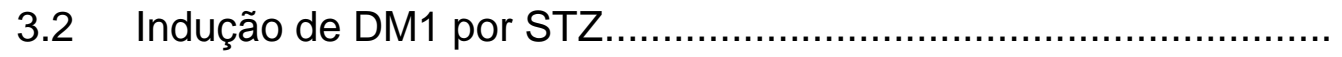

3.3 Monitoramento de glicemia.

3.4 Imunohistoquímica

3.5 Análise histopatológica................................................... 40

3.6 A Avaliação de leucócitos por citometria de fluxo (FACS)

3.7 Extração de RNA...

3.8 Extração de DNA para avaliação da microbiota intestinal............... 41

3.9 Reações de PCR em tempo real

3.10 Quantificação de citocinas por ELISA

3.11 Pré-tratamento com antibióticos

3.12 Permeabilidade intestinal pela análise de FITC-Dextran.

3.13 Cultura de Macrófagos derivados da Medula óssea (BMMs) e leucócitos derivados do LNM e estímulo com DNA fecal.

3.14 Detecção da ativação de caspase-1 por western blot. 
3.15 Imunofluorescência.

3.16 Isolamento de células T naïves por sorting e diferenciação para Th17 in vitro.

3.17 3.17 Forma de analises dos resultados.

\section{Resultados}

4.1 O inflamassoma AIM2 é ativado nos LNPs e mucosa intestinal durante o DM1

4.2 A ativação do receptor AIM2 contribui para a proteção ao DM1.

4.3 A ativação do receptor AIM2 controla à translocação de bactérias da microbiota intestinal para os LNPs durante o DM1

4.4 A ativação do receptor AIM2 regula a expressão de proteínas de junção e a permeabilidade intestinal durante o DM1.

4.5 A ativação do receptor AIM2 regula a expressão de IL-18, IL-22, peptídeos antimicrobianos e produção de muco na mucosa intestinal...

4.6 O inflamassoma AIM2 é ativado em macrófagos em resposta ao DNA de bactérias da microbiota em disbiose.

4.7 A ativação do inflamassoma AIM2 por DNA de uma microbiota em disbiose aumenta expansão de linfócitos Th17 in vitro.

4.8 O receptor AIM2 atua como um regulador positivo durante a 65 diferenciação de linfócitos Th17.

4.9 O receptor AIM2 regula à expressão de genes relacionados à 67 resposta de linfócitos Th17 na mucosa intestinal.

4.10 A deficiência de AIM2 reduziu a população de linfócitos Th17 nos 70 LNMs e LNPs durante o DM1

4.11 A ativação de AIM2 não alterou a população de linfócitos Tc17 nos LNPs durante o DM1

4.12 A deficiência de AIM2 prejudica a produção de citocinas relacionadas ao perfil de reposta Th17 durante o DM1

4.13 A ativação do receptor AIM2 promoveu a migração de neutrófilos intestinais.

4.14 A deficiência de AIM2 potencializou a população de linfócitos Th1 nos LNP durante o DM1 
4.15 A deficiência de AIM2 potencializou a população de linfócitos Tc1 nos LNP durante o DM1

4.16 A deficiência de AIM2 aumenta à produção de citocinas do perfil Th1/Tc1 no pâncreas durante o DM1

4.17 A deficiência de AIM2 aumenta à expressão de genes relacionados a resposta imune inata nos LNP

5. Discussão 86

6. Conclusão 99

7. Referências bibliográficas 101

8. Anexos 


\section{RESUMO}

O diabetes tipo 1 (DM1) é uma doença autoimune caracterizada pela destruição das células $\beta$ presentes nas ilhotas pancreáticas por linfócitos $T$ autorreativos, especialmente Th1 e Th17, levando o indivíduo a um estado de hiperglicemia. Embora existam diversos estudos que abordam a resposta imune adaptativa no contexto do DM1, poucos trabalhos tentaram elucidar o papel da resposta imune inata no desenvolvimento da doença. Neste contexto, observamos que camundongos WT pré-diabéticos possuem um aumento significativo na expressão gênica e proteica do receptor AIM2 e de moléculas relacionadas à sua via de ativação e sinalização (Caspase-1, IL-1ß e IL-18) nos linfonodos pancreáticos (LNPs) e no íleo. Posteriormente, foi verificado que camundongos deficientes do receptor AIM2 tornaram-se mais suscetíveis ao DM1, comprovado por elevados níveis de glicose sanguínea e menor produção de insulina em relação aos animais selvagens (WT) após a administração com estreptozotocina (STZ). Tal suscetibilidade está relacionada a um processo de disbiose e aumento da translocação de bactérias da microbiota intestinal para os LNPs de camundongos AIM2-/. . De maneira interessante, o inflamassoma AIM2 foi ativado apenas na presença de DNA fecal de animais diabéticos, que possui uma microbiota em disbiose, uma vez que resultou na produção significativa da citocina IL-1 $\beta$. Também foi constatado que a ativação do receptor AIM2 na mucosa intestinal regulou a expressão gênica e proteica de proteínas de junção celular, peptídeos antimicrobianos e mucinas, como forma de minimizar a translocação de bactérias da microbiota para os LNPs. Adicionalmente, foi visto que a ativação do receptor AIM2 contribui para a indução de células Th17 intestinais, para a migração de neutrófilos no intestino, assim como para a expressão das citocinas IL-23, IL-17 e IL-22 no íleo. Por fim, mostramos que o receptor AIM2 modulou negativamente a ativação de células dendríticas expressando TLR4 e TLR9, que correlacionou com o aumento de células Tc1 patogênicas nos LNPs. De forma geral, nossos resultados demonstram que a ativação do receptor AIM2 na mucosa intestinal desempenha um importante papel em controlar a homeostase da microbiota intestinal, manter a integridade da barreira intestinal, e consequentemente 
Palavras chave: diabetes tipo 1; AIM2; resposta imune inata; microbiota; Th1 


\section{ABSTRACT}

Type 1 diabetes (T1D) is an autoimmune disease characterized by the destruction of $\beta$ cells present in the pancreatic islets by autoreactive $T$ lymphocytes, especially Th1 and Th17, leading to a state of hyperglycemia. There are many studies that address the role of adaptive immune response, so only some studies have attempted to elucidate the role of the innate immune response in the context of T1D. In this regard, we observed that pre-diabetic WT mice have a significant increase in the gene and protein expression of the AIM2 receptor and in molecules related to its activation and signaling pathways (Caspase-1, IL$1 \beta$ and IL-18) in the pancreatic lymph nodes (PLNs) and in the ileum. Subsequently, it was verified that AIM2 receptor deficient mice became more susceptible to T1D, as proved by blood glucose levels and lower insulin production compared to wild-type mice (WT) after administration of streptozotocin (STZ). This susceptibility was related to a process of dysbiosis and increased translocation of bacteria from gut microbiota to $\mathrm{PLNs}$ in $\mathrm{AlM}^{-/}$mice. Interestingly, the AIM2 inflammasome was activated in the presence of fecal DNA from diabetic mice, which has a gut microbiota in dysbiosis, since resulted in significant production of IL-1 $\beta$. It was found that activation of the AIM2 receptor in the intestinal mucosa regulated the gene and protein expression of tightjunction proteins, antimicrobial peptides and mucins in order to minimizing a bacterial translocation of the microbiota to the PLNs. In addition, it was seen that activation of the AIM2 receptor contributes to induction of intestinal Th17 cells, to neutrophil migration in the intestine, as well as for expression of IL-23, IL-17 and IL-22 cytokines in the ileum. Finally, we show that the AIM2 receptor negatively modulated the activation of dendritic cells expressing TLR4 and TLR9, which correlated with the increase of pathogenic Tc1 cells in the PLNs. In general, the results demonstrate that activation of the AIM2 receptor in the intestinal mucosa plays an important role in controlling the composition of gut microbiota homeostasis, maintaining the intestinal barrier function, and consequently reducing the bacterial translocation to the PLNs, conferring a protective effect to the immunopathogeny against to DM1.

Keywords: Type 1 diabetes; AIM2; innate immune response; gut microbiota; 


\section{Introdução}




\subsection{Aspectos gerais sobre o Diabetes Mellitus tipo 1.}

O Diabetes Mellitus tipo 1 (DM1) é uma doença crônica de caráter autoimune, no qual células $\beta$ produtoras de insulina são destruídas por linfócitos $\mathrm{T}$ autorreativos, o que leva o indivíduo à um estado de hiperglicemia e consequentes complicações em vários órgãos, devido à falta de insulina(REDONDO et al., 2008). A incidência de DM1 tem aumentado significativamente desde a década de 1950 até os dias atuais, o que já levou a acometer cerca de 10 a 20 milhões de pessoas, às quais incluem na maioria dos casos crianças e adolescentes, porém também pode se desenvolver em indivíduos na fase adulta. Estudos mais recentes indicam que este número irá duplicar em crianças menores de 5 anos até o ano de 2020 (PATTERSON, C. C. et al., 2009).

As principais causas relacionadas ao DM1 ainda são pouco conhecidas, embora vários estudos indicam fatores genéticos e ambientais como as principais causas que levam à suscetibilidade ao DM1. Os fatores genéticos incluem algumas regiões cromossomais que conferem suscetibilidade, como por exemplo, os genes que codificam o HLA (localizado no cromossomo 6p21), a região do gene que codifica insulina (localizada no cromossomo 11p15) e as regiões do gene que codificam as moléculas CTLA/4e CD28 (localizada no cromossomo 2q31-q33) (BIROS; JORDAN; BAXTER, 2005). Os fatores ambientais estão relacionados a infecções virais, produtos alimentares, vacinação, toxinas, estresse e alterações da microbiota intestinal(REWERS et al., 1988). De forma geral, o desenvolvimento do DM1 inclui quatro estágios distintos: (I) Fase pré-clínica, onde ocorre a autoimunidade dirigida contra as células $\beta$ das ilhotas pancreáticas, o que leva à insuficiência da produção de insulina, e consequente diminuição das respostas insulínicas à glicose intravenosa ou oral; (II) início do diabetes clínico; (III) remissão transitória; (IV) diabetes associado à complicações agudas, crônicas e óbito (REWERS et al., 1988).

O desenvolvimento do DM1 inicia-se no pâncreas onde as células $\beta$ pancreáticas aumentam a produção de interferon do tipo $\alpha$ (IFN- $\alpha)$ e posteriormente a expressão de MHC de classe I. Este evento expõe as células $\beta$ ao ataque de linfócitos T CD8 ${ }^{+}$autorreativos com especificidade para antígenos 
do pâncreas. Não obstante, os autoantígenos liberados pelas células do pâncreas são capturados e internalizados por células apresentadoras de antígenos (APCs) que migram para os linfonodos drenantes do pâncreas (linfonodos pancreáticos), apresentando tais antígenos via MHCIl para linfócitos T CD4+ que podem se diferenciar em subpopulações distintas, como Th1 ( $T$ CD4+ produtor de IFN- $\gamma$ ) ou Th17 (T CD4+ produtor de IL-17), ambos através da produção de suas citocinas vão colaborar para a destruição das células $\beta$ pancreáticas e consequente desenvolvimento da doença. Além disso, os autoantígenos das células $\beta$ pancreáticas juntamente com o auxílio de células $T$ CD4+ iniciam a conversão de linfócitos $B$ em plasmócitos, dando início a produção de autoanticorpos. Concomitantemente, linfócitos T CD8 ${ }^{+}$autorreativos são estimulados a proliferarem e migrarem para o pâncreas, causando a morte das células $\beta$ pancreáticas através da liberação de mediadores citotóxicos como granzima e perforina. Em alguns casos, linfócitos T reguladores (Treg) podem se sobrepor e controlar a resposta imune efetora, através da produção de IL-10 e consequente inibição de linfócitos T efetores. Tal fato, demonstra que o balanço entre a resposta autorreativa destrutiva e a reguladora promove um estado transiente de produção suficiente de insulina pelo indivíduo, mesmo após o início clínico da doença (LEHUEN et al., 2010).

\subsection{Mecanismos desencadeadores da autoimunidade no DM1}

Uma série de eventos ocorre durante o estabelecimento da fase préclínica até a fase clínica. Inicialmente, a associação entre a fatores genéticos e ambientais ocasiona o processo de morte celular das células $\beta$ e início da inflamação nas ilhotas pancreáticas ou insulite. Como consequência, as células $\beta$ passam a produzir grande quantidade de IFN- $\alpha$ e, posteriormente expressam auto-antígenos via MHC de classe I e passam a ser reconhecidas por meio de linfócitos T CD8 ${ }^{+}$autorreativos, que culmina na apoptose das mesmas pelas vias Fas/FasL ou devido a ação de mediadores solúveis como as perforinas e granzimas (LEHUEN et al., 2010).

Os macrófagos residentes nas ilhotas pancreáticas produzem IL-1 $\beta$, TNFa e mediadores bioquímicos, tais como óxido nítrico (NO) e espécies reativas de oxigênio (ROS) que potencializam a morte das células $\beta$ pancreáticas, indicando 
um importante papel destrutivo dessas células na fase inicial do DM1 (UNO et al., 2007). Concomitantemente, autoantígenos liberados pelas células $\beta$ são internalizados por células apresentadoras de antígenos (APCs) e transportados para o linfonodo pancreático drenante, os quais são processados e apresentados via MHC de classe II aos linfócitos T CD4+ autorreativos, que se diferenciam em linfócitos Th1/Th17, os quais induzem de forma direta ou indireta respectivamente, a morte das células $\beta$ por meio da produção de citocinas como IL-2, IFN-y e IL-17(MATHIS; VENCE; BENOIST, 2001).

A resposta de linfócitos Th17 tem sido amplamente estudada em modelos experimentais e em humanos com DM1. Tais células se diferenciam a partir de linfócitos T naives na presença das citocinas TGF- $\beta$ e IL-6, e posteriormente tem sua proliferação e função aumentada na presença de IL-23 e IL-1 $\beta$. Essas células apresentam como características principais a expressão de fatores de transcrição como RORyt, STAT3, NFAT1 e a produção das citocinas IL-17A, IL17F e IL-22 (IVANOV et al., 2006). Os primeiros estudos relacionando a resposta de células Th17 durante o DM1 demonstraram um significativo aumento de IL17 no pâncreas de camundongos NOD (EMAMAULLEE et al., 2009). Posteriormente, foi demonstrado que tais células participam para a exarcebação da doença através da observação de que a citocina IL-23 promovia a expansão destas células, contribuindo para o desenvolvimento do DM1 se co-administrada com múltiplas doses de STZ(MENSAH-BROWN et al., 2006). Em humanos, foi demonstrado que linfócitos Th17 estão aumentadas no sangue periférico de crianças com DM1(EMAMAULLEE et al., 2009). Contudo, o exato papel deste subtipo celular ainda não foi completamente elucidado. 


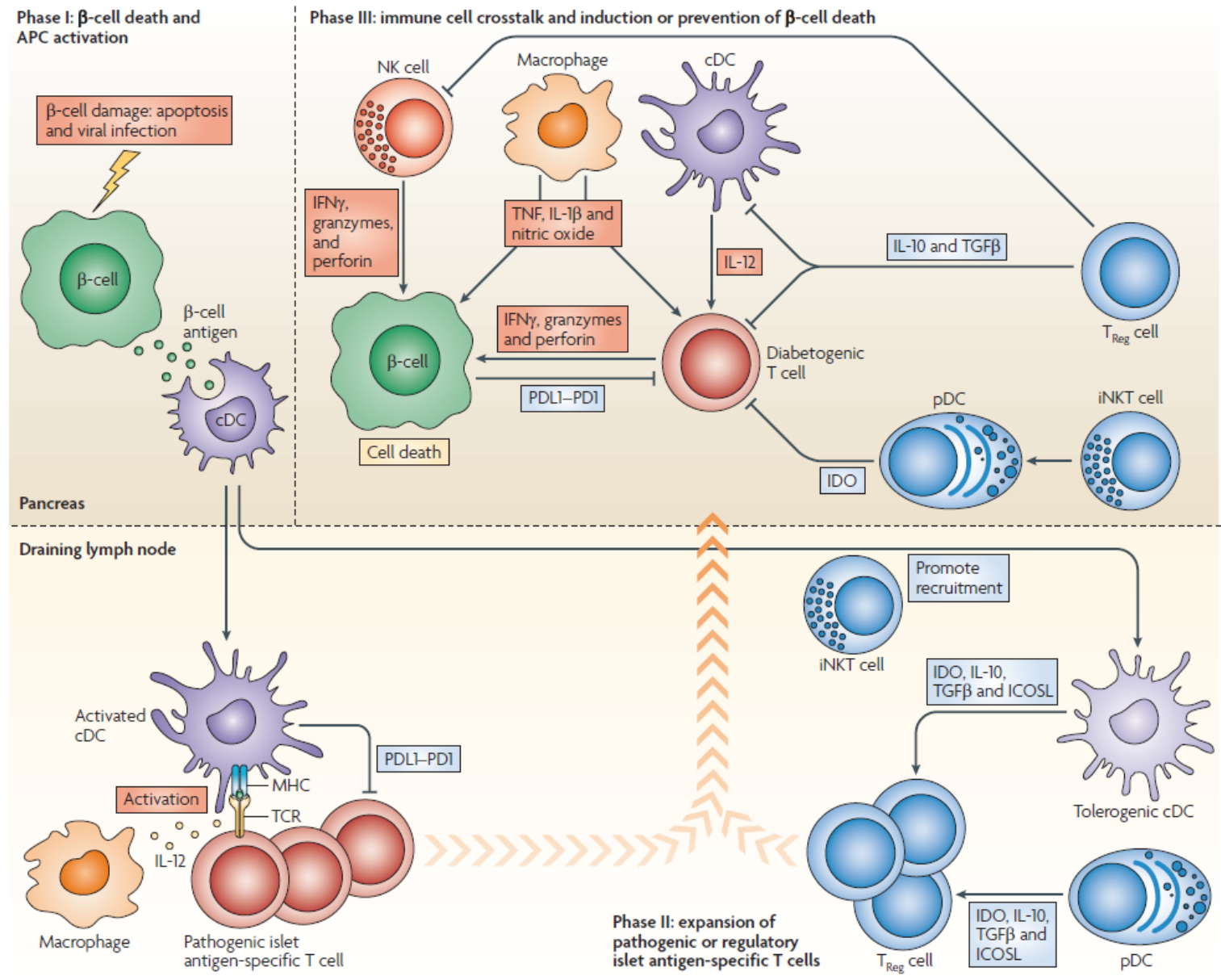

Esquema 1 Mecanismos celulares e moleculares relacionados com 0 desenvolvimento do DM1 (LEHUEN et al., 2010).

Um outro grupo de células encontradas em número aumentado no pâncreas de pacientes diabéticos são as células NK ("natural killer"). Estudos recentes demonstram que as células NK contribuem para a patogênese do DM1 decorrente da produção de IFN-y e de sua ação citotóxica que pode matar direta ou indiretamente as células $\beta$ do pâncreas(POIROT; BENOIST; MATHIS, 2004). Estas alterações inflamatórias criam um ambiente pró-inflamatório que favorece a resposta de linfócitos $T$ efetores (Teff), em detrimento de linfócitos Treg. Adicionalmente, o reconhecimento de auto-antígenos das células $\beta$ neste contexto pró-inflamatório por linfócitos T CD4+ promove a produção de citocinas e a conversão de linfócitos $B$ em plasmócitos, o que leva ao início da produção de auto-anticorpos (soroconversão) (KABAROWSKI et al., 2001).

Todavia, a tolerância mediada por linfócitos Tregs podem, em alguns casos, sobrepor e controlar a resposta imune efetora. Portanto, o balanço entre resposta autoimune destrutiva e resposta reguladora, promove um estado transiente de produção suficiente de insulina pelo indivíduo, denominado de fase 
de lua de mel. Eventualmente, a prevalência da resposta autoimune ocasiona a destruição quase que completa das células $\beta$ produtoras de insulina, sendo que cerca de apenas 10-30\% dessas células continuam funcionais após o início da doença (LEHUEN et al., 2010).

\subsection{Modelos experimentais para o estudo do DM1}

Atualmente, os estudos envolvendo DM1 são realizados amplamente em modelos experimentais, através da utilização de camundongos diabéticos não obesos (Non obese diabetic NOD). Foi postulado que o desenvolvimento da doença em camundongos NOD requer a presença de linfócitos T CD4+ e CD8 ${ }^{+}$, uma vez que clones de células $T$ provenientes de camundongos NOD respondem aos auto-antígenos das células $\beta$ pancreáticas. Em adição, foi demonstrado que camundongos NOD sem timo ou NOD/SCID (severecombinedimmunodeficiency) não desenvolvem a doença (CASTANO; EISENBARTH, 1990).

Uma outra forma de induzir o diabetes tipo 1 em modelos experimentais consiste na administração de estreptozotocina (STZ) em linhagens de camundongos C57BL/6 susceptíveis que pode induzir um quadro de diabetes que se assemelha em vários aspectos ao DM1 humano. A STZ é um composto químico transportado para o interior das células $\beta$ via proteína transportadora de glicose 2 (GLUT2), o que leva à uma toxicidade sítio-específica (WOOD; RAO; FREY, 1999). No interior das células, seus metabólitos promovem estresse oxidativo e leva à degradação do DNA, necrose tecidual e inflamação pancreática(LEY et al., 2005). No regime de múltiplas doses, a tolerância aos antígenos das ilhotas é abolida resultando tanto na indução de uma resposta humoral com produção de anticorpos(HEROLD et al., 1995), quanto uma resposta celular mediada por linfócitos T CD4 e CD8 autorreativos específicos (HORWITZ et al., 2002), assim como citotoxicidade mediada por células NK e macrófagos que leva à inflamação e destruição das células $\beta$ do pâncreas (KANTWERK-FUNKE; BURKART; KOLB, 1991). 


\subsection{Receptores NLRs e ALRs: Ativação e formação do complexo inflamassoma.}

Os receptores NLR (NOD-likereceptors) são receptores intracelulares presentes no citoplasma das células, que apresentam um importante papel na imunidade inata através da detecção de padrões moleculares associados a patógenos (PAMPs) e padrões moleculares associados à morte celular (DAMPs). Estes receptores são compostos por três domínios distintos: uma região carboxiterminal rica em leucina, denominada LRR, são responsáveis pelo reconhecimento antigênico; um domínio NOD ou NBS (nucleotidebindingoligomerizationdomain), responsável pela oligomerização do receptor e um aminoterminal, o qual desencadeia a função efetora do receptor e que pode conter domínios como CARD (caspase recruitmentdomain), PYD (pyrin), BIR (baculoviralinhibition of apoptosisrepeatdomain) ou TIR (similar to IL-1 receptor) (GUO; CALLAWAY; TING, 2015).

Os membros da família NLR podem ser divididos em dois grupos de acordo com suas diferenças estruturais e funcionais. O primeiro grupo consiste nos receptores NOD1 e NOD2, que são responsáveis pela montagem de complexos que ativam as vias de sinalização dependente de MAPK (mitogenactivatedproteinkinase), que resulta na translocação do fator de transcrição NFKB (nuclear factorkappa-light-chain-enhancer of activated $B$ cells) e subsequente produção de citocinas tais como TNF- $\alpha$, IL-6, pró-IL-1 $\beta$ e pró-IL-18(AKIRA, 2009).

Outro grupo funcional do NLR inclui membros como NLRP1, NLRP3, NLRP6 e NLRC4, os quais medeiam à montagem das plataformas moleculares chamadas de inflamassomas. Após reconhecerem seu respectivo ligante, ocorre a oligomerização destes receptores NLR, o que permite o recrutamento da proteína adaptadora ASC (apoptosis-associatedspeck-likeproteincontaining a $C A R D$ ). ASC contém uma região $\mathrm{N}$-terminal PYD e uma $\mathrm{C}$-terminal CARD que permite o recrutamento de caspases inflamatórias, especialmente caspase-1, para a plataforma de sinalização através de interações CARD-CARD (GUO et al., 2015). Em seguida, a pró-caspase 1 se liga ao complexo através de seu domínio CARD ao domínio CARD presente na proteína ASC, cuja principal 
função é clivar a pró-caspase-1 em caspase-1 ativa, que por sua vez irá clivar pró-IL-1 $\beta$ e pró-IL-18 em suas formas maduras e biologicamente ativas (DOMBROWSKI et al., 2011).

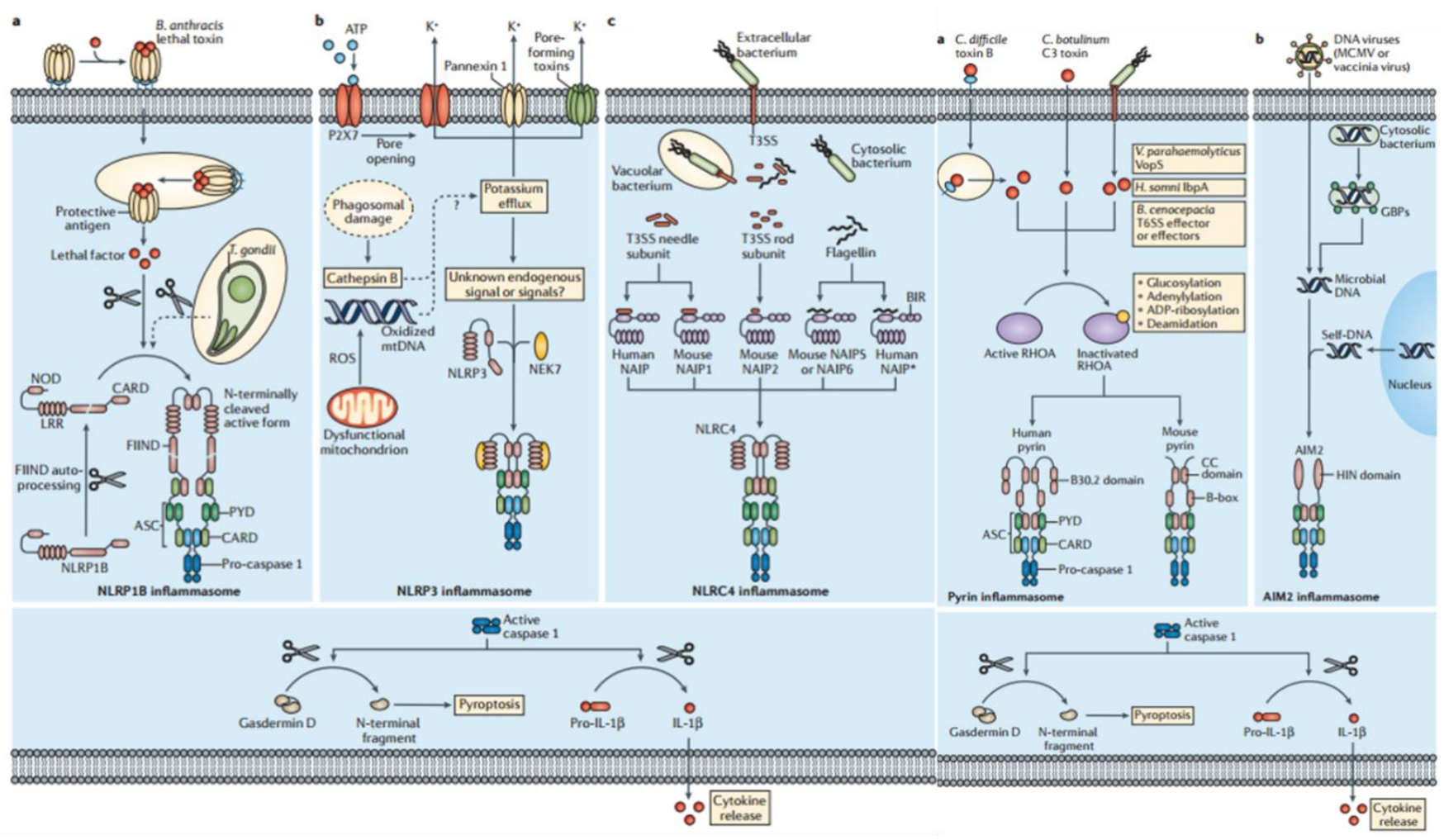

Esquema 2 Mecanismos de ativação do complexo inflamassoma (BROZ; DIXIT, 2016).

Existe outra classe de inflamassomas que, ao invés de NLRs, possuem membros da família PYHIN como sensores, os também chamados "Aim-like receptors" (ALRs). Essas proteínas são codificadas por 4 genes em humanos: "absent in melanoma 2" (AIM2); "interferon gamma induible protein 16" (IFI16); "Myeloidcell nuclear differentiation antigen" (MNDA); "interferon-inducible protein X" (IFIX); e outros 13 em camundongos. Os ALRs são caracterizados por possuírem a presença de um domínio PYD e um ou mais domínios de ligação a DNA chamado HIN-200. Os ALRs AIM2 e IFI16 já foram descritos como capazes de ativar inflamassoma e, diferentemente dos NLRs, parecem ligar-se diretamente a seus ativadores, que são os DNAs de dupla fita (RATHINAM et al., 2010). 
O receptor AIM2 localiza-se predominantemente no citosol, e possui um domínio PYD na posição N-terminal, e um domínio HIN200 na posição Cterminal. Mediante ligação do DNA ao domínio HIN200, AIM2 recruta ASC através de seu domínio PYD, e ASC atua como ponte de ligação à pro-caspase1, dando origem assim ao inflamassoma de AIM2 (FERNANDES-ALNEMRI et al., 2009). Estudos recentes sugerem que AIM2 se apresenta em uma conformação auto-inibitória gerada pela interação de seus dois domínios. Mediante a ligação ao DNA há uma mudança de conformação permitindo a liberação de seu domínio PYD para interagir com ASC. Como AIM2 não possui domínio NATCH, ele usa o DNA como matriz para oligomerização. Surpreendentemente, AIM2 não parece reconhecer sequências específicas de DNA, ao invés disso, os únicos requerimentos para reconhecimento de DNA por AIM2 são que eles sejam DNAs de dupla fita e com no mínimo 80 pares de bases (JIN et al., 2012).

\subsection{Evidências da ativação de inflamassomas na autoimunidade.}

Embora tenha sido confirmada uma importante implicação dos receptores NLR na ativação dos mecanismos inatos devido ao reconhecimento de constituintes microbianos e/ou componentes endógenos, seu papel na regulação da resposta imune adaptativa no contexto de autoimunidade permanece incerto.

No modelo de encefalomielite autoimune experimental (EAE), a ativação dos receptor NLRP3 está associada com a suscetibilidade à doença, uma vez que o mesmo está envolvido no desenvolvimento de células Th1 e Th17 e progressão da doença (GRIS et al., 2010). De maneira similar, foi demonstrada uma associação de mutações no gene NLRP1 e suscetibilidade genética à doença autoimune de Addison, uma condição autoimune associada com destruição do córtex adrenal que resulta em deficiência de mineralocorticóides, glicocorticóides e andrógenos pela glândula adrenal (ZURAWEK et al., 2010).

Da mesma forma que os NLRs, o inflamassoma AIM2 parece estar envolvido na patogênese de doenças autoimunes. Foi demonstrado que 0 acúmulo de DNA na pele pode servir como um sinal de perigo, pois induzem a ativação do AIM2 dependente de IL-1 $\beta$ em células da pele o que contribui para 
a patogênese da psoríase (DOMBROWSKI et al., 2011). Também foi evidenciado que leucócitos de pacientes com lúpus eritematoso sistêmico (SLE) apresentam elevada expressão de AIM2, sugerindo sua participação na patogênese do SLE, baseado na sua capacidade de reconhecer DNA citoplasmático (KIMKONG; AVIHINGSANON; HIRANKARN, 2009). Em contrapartida, um estudo recente mostrou que o inflamassoma AIM2 possui um papel crucial na proteção da colite determinada pela infecção por Salmonela através da manutenção da barreira intestinal e regulação da sinalização da proteína AKT, que acarreta a expressão de proteínas de junção epitelial e impossibilita o aumento da permeabilidade intestinal, (HU, G. Q. et al., 2016).

De forma semelhante, Ratsimandresy et al., (2016) demonstraram que a deficiência de AIM2 prejudica a produção de IL-18 e consequente ação da IL-22, o que leva à disbiose intestinal e elevada suscetibilidade à colite devido à falha na expressão de peptideos antimicrobianos. Sendo assim, o estudo comprovou que o inflamassoma AIM2 previne a disbiose intestinal através do reconhecimento de DNA microbiano nas células epiteliais do intestino e consequente produção de IL-18. Por sua vez, a IL-18 potencializou a atividade de IL-22 no colón a qual promove a expressão de peptídeos antimicrobianos como Reg3 $\beta$ e Reg3y.

Em pacientes diabéticos verificou-se também forte correlação entre polimorfismos do NLRP1 e NLRP3 com maior predisposição à doença (PONTILLO et al., 2010). Adicionalmente, um estudo recente demonstrou que a deficiência do inflamassoma NLRP3 impede à migração de células $T$ para as ilhotas pancreáticas através da inibição da quimiotaxia, o que levou à resistência ao desenvolvimento do DM1 em camundongos NOD, apontando um importante papel destes receptores na patogênese da doença (HU, C. et al., 2015). Neste sentido, Carlos et. al., (2017) demonstraram que a ativação do inflamassoma NLRP3 por DNA mitocondrial contribui para a suscetibilidade ao DM1 induzido por STZ, através da produção de citocinas IL-1ß e IL-18, que potencializam a resposta de células Th17 e Th1 autoreativas, contribuindo assim para a destruição das células $\beta$ pancreáticas.

Contudo, em relação a atuação do inflamassoma AIM2 no DM1, não existem evidências na literatura que demonstrem um papel do mesmo na 
suscetibilidade ou resistência à doença, sendo o nosso estudo o primeiro a estudar o papel deste receptor e de sua via de sinalização no DM1.

\subsection{Envolvimento da microbiota intestinal no DM1.}

Inúmeros estudos têm demonstrado que uma possível interação entre uma microbiota intestinal alterada e a suscetibilidade ao DM1(BRUGMAN et al., 2006); (MULLANEY et al., 2018). A introdução de técnicas baseadas em sequenciamento ribossomal revelou que a maioria dos microrganismos presentes na microbiota humana pertencem à 3 grandes filos: os Bacteroidetes gram-negativos e os Actinobacteria e Firmicutes gram-positivos que incluem os Lactobacillus, Clostridium, Bacillus e Mycoplasma. Diferente do genoma humano, o genoma de microrganismos presentes na microbiota intestinal é passível de alterações dinâmicas na configuração de seus componentes com o intuito de adaptação de um componente individual ou de uma comunidade em resposta ao tipo de alimentação, alguma anormalidade ou uso de antibióticos. $O$ estudo do genoma destes microrganismos compreende o microbioma, enquanto que as mudanças dinâmicas no genoma microbiano ou diversidade metabólica são alvos de estudos da metagenômica e metabolômica(LEY et al., 2005).

Diversos achados indicam que alteração da microbiota intestinal, ruptura da barreira intestinal ou da imunidade de mucosa contribuem para a patogênese do DM1. Os estudos prévios que introduziram o conceito de que a exposição da microbiota interfere no DM1 foram conduzidos em camundongos NOD, que apresentam maior predisposição à doença em condições livre de patógenos ou "germ-free" (MORDES et al., 2004). Sendo assim, é concebível que a infecção com bactérias ou estímulo com antígenos bacterianos atrase o estabelecimento de DM1 em camundongos NOD (SAI; RIVEREAU, 1996). Entretanto, outro estudo comprovou que a incidência do DM1 em camundongos NOD fêmeas não necessariamente é afetada por condições "germ-free" (KING; SARVETNICK, 2011). Ao contrário, este estudo mostrou que a inoculação de uma bactéria específica promove resistência ao DM1 ao invés de um microambiente bacteriano em especial. Também foi demonstrado que este efeito protetor é conferido pela alta produção de TGF- $\beta$ (LEY et al., 2005). A capacidade do TGF- 
$\beta$ em induzir a diferenciação de linfócitos Treg poderia explicar seu efeito imunomodulador no DM1.

Adicionalmente, Goffau, et al., (2013) demonstram que pacientes com DM1 apresentam disbiose intestinal, tendo maior abundância de bactérias do filo Bacteroidetes em amostras de fezes, quando comparados com indivíduos controles. Não obstante, estudos prévios, já demonstraram que a disbiose intestinal está intimamente relacionada com translocação bacteriana do lúmen para tecidos adjacentes(BISCHOFF et al., 2014); (DE GOFFAU et al., 2014). Neste sentido, um estudo recente desenvolvido pelo nosso grupo de pesquisa constatou que alterações da microbiota intestinal, associada à translocação de bactérias para os linfonodos pancreáticos, acarretam a ativação do receptor NOD2 em células mielóides e expressão de citocinas que contribuem para uma resposta pró-inflamatória mediada por linfócitos Th1 e Th17, o que contribui para o processo de insulite e consequente desenvolvimento do DM1 induzido por STZ. Isto sugere que o a disbiose observada em pacientes com DM1, pode ser um importante fator ambiental desencadeante da doença (COSTA et al., 2016).

\subsection{Permeabilidade intestinal: Conceitos e correlações com 0 desenvolvimento do DM1}

Em condições normais, o epitélio gastrointestinal é formado por uma camada de células epiteliais, que permitem uma absorção eficiente de nutrientes pelo organismo, e ao mesmo tempo, constitui uma barreira que impede o transporte de substâncias nocivas da região luminal do intestino para a circulação sanguínea e tecidos adjacentes (SUZUKI, 2013). A barreira epitelial também possui um papel fundamental no controle do acesso de microrganismos para tecidos adjacentes, assim como de componentes solúveis que são secretados, como por exemplo, imunoglobulinas, muco, defensinas e outros produtos antimicrobianos(ARRIETA; BISTRITZ; MEDDINGS, 2006).

As células epiteliais também exercem a função de controlar a permeabilidade intestinal. Tal permeabilidade seletiva é mantida principalmente pelas uniões intercelulares estreitas que se estabelecem entre as células epiteliais, denominadas de tight-juctions (TJ) ou proteínas de junção. As TJ são complexos proteicos formados por proteínas transmembranas tais como 
claudina, ocludina, moléculas de adesão juncional (JAM), assim como moléculas citosólicas como as proteínas ZO(ARRIETA et al., 2006).

Estudos recentes têm demonstrado que a deficiência na expressão de ocludina e ZO-1 induz uma aumentada permeabilidade de macromoléculas, o que indica que tais proteínas possuem um papel importante na manutenção da integridade intestinal. Por outro lado, a deficiência de claudina-2 leva a uma redução na condução transepitelial de moléculas, assim como a permeabilidade ao $\mathrm{Na}^{+}($SUZUKI, 2013). Nos últimos anos, alterações na permeabilidade intestinal vem sendo associadas com diversas doenças, como por exemplo o DM1. Estudos em pacientes com DM1, demonstraram que os mesmos possuem um aumento da permeabilidade intestinal ao monossacarídeo manitol, indicando uma injúria na integridade intestinal(CARRATU et al., 1999).

Neste sentido, Neu, et al. (2005) demonstraram que em um modelo experimental de DM1, ratos diabéticos apresentaram uma diminuição significativa da expressão proteica de claudina-1 no intestino delgado, e isso correlacionou-se com uma maior permeabilidade intestinal observada através dos níveis de lactulose e manitol na urina, após sua administração oral (NEU et al., 2005). Tais dados suportam a hipótese de que uma barreira intestinal prejudicada pode estar relacionada com o desenvolvimento do DM1.

\subsection{Importância dos linfócitos Th17 na mucosa intestinal}

A homeostase do sistema imune de mucosa é mantida através de uma constante regulação entre bactérias comensais, células epiteliais do intestino e as células do sistema imune de mucosa (HOOPER; LITTMAN; MACPHERSON, 2012). A ativação de células do sistema imune de mucosa pode ser mediada por antígenos comensais ou externos, como bactérias patogênicas. A imunidade inata é a primeira linha de defesa a ser ativada em resposta a translocação de bactérias comensais para a lâmina própria ou infecções por bactérias patogênicas. Uma série de receptores de reconhecimento padrão, como os Tolllike receptors (TLRs) e Nod-like receptors (NLRs) são ativados em células epiteliais do intestino e células do sistema imune (Macrófagos e Células Dendríticas) em resposta aos antígenos comensais e a patógenos externos (YUAN; WALKER, 2004). 
Como descrito no item 1.4, a ativação dos receptores NLRs ou ALRs, por diversos ligantes leva a formação de uma plataforma molecular denominada inflamassoma que através da enzima caspase-1 cliva as formas imaturas de IL$1 \beta$ e IL-18 em suas formas maturas. As citocinas IL-1 $\beta$ e IL-18 são membros da família de citocinas IL-1 e possuem um papel fundamental na manutenção da homeostase intestinal através da ativação de uma série de células na mucosa, contribuindo para a defesa do hospedeiro contra diversos microrganismos.

Citocinas da família IL-1 são importantes na modulação da resposta de células Th17 e Th22. Durante a diferenciação de células T helper, a citocina IL$1 \beta$ em associação com IL-6 e IL-23 promovem a diferenciação de células Th17 produtoras de IL-17 e IL-22 (MAILER et al., 2015). O papel das células Th17 no intestino está relacionado à manutenção da homeostase intestinal. Neste local, a produção de citocinas pró-inflamatórias decorrente de sinais derivados da ativação de receptores NLRs e TLRs (Toll like receptors) em determinadas subpopulações de DCs e macrófagos parece ser importante na diferenciação das células Th17 intestinais(ATARASHI; TANOUE; HONDA, 2010). As células Th17 diferenciadas desempenham diversas funções importantes no intestino tais como a manutenção da integridade da barreira intestinal e o controle do balanço das populações de bactérias presentes na microbiota intestinal.

Além das células Th17 regularem positivamente a granulopoiese, elas também induzem o recrutamento de neutrófilos do sangue para LP intestinal, já que promovem a expressão de quimiocinas como CXCL-1 e CXCL-2 pelas células epiteliais e fibroblastos da mucosa intestinal(AUJLA; DUBIN; KOLLS, 2007). Não obstante, as células Th17 estão envolvidas diretamente com a regulação de componentes da barreira física intestinal por reforçar as TJ e promover uma maior associação das proteínas claudina 1 e 2 na membrana das células epiteliais(KINUGASA et al., 2000). As células Th17 também induzem a expressão de genes de mucinas por células caliciformes presentes no intestino, as quais são proteínas glicosiladas que formam parte da camada de muco que recobre as células epiteliais (CHEN et al., 2003). Adicionalmente, foi verificada a correlação da produção de IL-17 com o aumento da expressão de $\beta$-defensinas no cólon, assim como a capacidade desta citocina em promover a expressão do receptor polimérico de $\lg$ e a liberação de $\lg A$ pelas células $B$ presentes no intestino (ISHIGAME et al., 2009). 
Como mencionado acima, a resposta de células Th17 intestinais é de suma importância para a manutenção da permeabilidade intestinal. Estudos recentes demonstram que a neutralização de IL-17 em um modelo de colite induzido por DSS resulta em uma elevada permeabilidade intestinal. De maneira interessante, a IL-17 regula a localização celular da proteína de junção ocludina, que está relacionada à manutenção de uma maior integridade da barreira epitelial (LEE et al., 2015).

Sabe-se que as citocinas IL-1 $\beta$ e IL-18 são fundamentais para a manutenção da resposta de células Th17 intestinais, mas ainda pouco se sabe sobre a ação dessas citocinas no controle da permeabilidade intestinal e na translocação de bactérias do lúmen intestinal. Com relação à atuação destas citocinas no diabetes tipo 1 , estudos recentes demonstram que pacientes com DM1 possuem uma diminuição na expressão gênica de IL-18 e IL-17 em amostras de intestino, o que sugere que a reduzida produção destas citocinas mucosa intestinal pode interferir na progressão do DM1. 
2 Objetivos 


\subsection{Objetivo geral}

Investigar a expressão e a importância do receptor AIM2 na modulação da resposta imune celular durante a progressão do DM1, com ênfase no controle da permeabilidade intestinal e da translocação bacteriana em modelo experimental.

\subsection{Objetivos específicos}

- Quantificar a expressão gênica e proteica de AIM2 e das vias de sinalização downstream (caspase-1, ASC, IL-1ß e IL-18) nos linfonodos pancreáticos (LNP) e intestino (íleo) em camundongos diabéticos;

- Elucidar se a ativação do inflamassoma AIM2 controla a disbiose, permeabilidade intestinal, translocação bacteriana e expressão de proteínas de junção e adesão celular no epitélio intestinal;

- Verificar se a ativação do inflamassoma AIM2 promove a produção de defensinas, peptídeos anti-microbianos e mucina no intestino;

- Testar se o DNA fecal de animais não-diabéticos e diabéticos causa a ativação do inflamassoma AIM2 em macrófagos.

- Determinar o exato papel do inflamassoma AIM2 na proteção durante o DM1, com ênfase no perfil de resposta celular Th17/Th1 nos linfonodos pancreáticos (LNP) e mesentéricos (LMN).

- Identificar os mecanismos inflamatórios e/ou imunoreguladores desencadeados após a ativação do receptor AIM2 no DM1 experimental. 
3 Materiais \& Métodos 


\subsection{Animais.}

Foram utilizados camundongos C57BL/6, machos: selvagens (wild typeWT) e deficientes de AIM2, entre 8 a 10 semanas de idade, pesando entre 20 e 25 gramas. Todos os procedimentos foram realizados de acordo com os princípios propostos pelo Colégio Brasileiro de Experimentação Animal (COBEA) e aprovado pelo Comitê de Ética em Experimentação Animal (CETEA) da Universidade de São Paulo (Protocolo 215/2016).

\subsection{Indução de DM1 por STZ.}

Os animais receberam cinco injeções i.p. diárias de estreptozotocina STZ na concentração final de $40 \mathrm{mg} / \mathrm{Kg}$ de peso do animal em solução de citrato de sódio $25 \mathrm{mM}, \mathrm{pH}=4,0$.

\subsection{Monitoramento de glicemia.}

A glicemia foi avaliada em camundongos WT C57BL/6 ou deficientes para AIM2 semanalmente a partir da primeira dose de STZ. Para tanto, uma gota de sangue foi retirada da base da cauda, de cada animal, e a taxa de glicose foi quantificada no aparelho Prestige LX (Prestige Smart System).

\subsection{Imunohistoquímica.}

Os cortes histológicos de $4 \mu \mathrm{m}$ foram incubados com tampão citrato/ácido cítrico $(\mathrm{pH}=6) 2$ vezes durante 5 minutos no microondas para exposição dos antígenos de superfície celular. As amostras foram incubadas com anticorpo primário para as moléculas de interesse. Após o período de incubação as amostras foram lavadas com PBS/Tween e incubadas com anticorpo secundário anti-IgG de coelho marcado com biotina (Vector, VA, USA). Finalmente, foi realizado o tratamento com o substrato DAB (ResearchGenetics) e contracoloração com hematoxilina. 


\subsection{Análise histopatológica.}

A avaliação histopatológica do infiltrado inflamatório foi realizada após coloração com hematoxilina e eosina (HE) em amostras fixadas em PBS/formaldeído 10\%. Foram analisadas em média de 100 ilhotas por grupo, que receberam um score baseado no nível do infiltrado inflamatório, sendo classificadas em: sem insulite, peri-insulite ou insulite invasiva.

\subsection{A Avaliação de leucócitos por citometria de fluxo (FACS).}

A análise quantitativa e fenotípica de células extraídas do LNP e LNM foi realizada por citometria de fluxo. Após digestão enzimática das amostras, serão identificados e quantificados leucócitos presentes no nos LNPs/LNMs de camundongos WT ou AIM2 ${ }^{-/}$diabéticos e controles. Para caracterização de Th17, Th1, Tc1, Tc17, a expressão de IL-17 ou IFN- $\gamma$ em células $\mathrm{CD}^{+}{ }^{+}$foi determinada após cultivo dos leucócitos dos linfonodos, in vitro, com forbolmiristato-acetato (PMA) e ionomicina, e subsequentemente brefeldina. Além disso, o infiltrado celular nos tecidos coletados também foi analisado para quantificação de células dendríticas e neutrófilos. As células foram lavadas e ressuspendidas em Fcblock (para bloquear ligações inespecíficas) por 30 minutos a $4^{\circ} \mathrm{C}$ e em seguida com $1.0 \mu \mathrm{g}$ de anticorpos monoclonais específicos aos marcadores determinados acima, conjugados com FITC, PE, PerCP ou APC por 30 minutos à $4^{\circ} \mathrm{C}$. Após incubação com os anticorpos, as amostras foram lavadas 2 vezes com PBS-BSA e centrifugadas a $250 \times \mathrm{g}$ por 10 minutos. Os leucócitos foram adquiridos em FACSCanto II (Becton\&Dickson®), San Jose, CA, USA) e as análises serão feitas usando o software FlowJo (Treestar®).

\subsection{Extração de RNA.}

A extração do RNA total das amostras dos LNP/LNM e íleo foi realizada utilizando o kit de extração de RNA (Promega) de acordo com as recomendações do fabricante. As amostras de RNA foram suspensas em $50 \mu l$ de água deionizada e livre de Rnase, sendo então armazenadas a -70 C. A concentração 
de RNA foi determinada utilizando o aparelho NanoDrop 2000 (Thermo Fisher Scientific, USA).

\subsection{Extração de DNA para avaliação da microbiota intestinal}

As amostras de fezes, LNPs e fezes foram coletados a fim de avaliar a expressão gênica de filos de bactérias da microbiota intestinal (Bacteroidetes, Firmicutes, Proteobacteria, Actinobactéria e Verrucomicrobia). O DNA das amostras de fezes foi extraído utilizando o kit de extração de DNA QuiampStool (Quiagen) de acordo com as instruções do fabricante, enquanto que o DNA dos LNPs foi extraído utilizando o kit de extração de DNA DneasyBlood\&Tissue (Quiagen) de acordo com as instruções do fabricante. A concentração de DNA foi determinada utilizando o aparelho NanoDrop 2000 (Thermo Fisher Scientific, USA).

\subsection{Reações de PCR em tempo real.}

A expressão quantitativa dos genes das moléculas AIM2, pró-IL-1 $\beta$ e próIL-18, dos fatores de transcrição, STAT-3, IRF4, N-FAT, RORyt, e das citocinas IL-23, IL-17, IL-6, TFG- $\beta$ e IL-22, das proteínas de adesão e junção celular ocludina e claudina-2, ZO-1, e mucinas 1 e 2, TIr2, TIr4, TIr9, Myd88, Ifn- $\alpha$ e $\beta$, Nod2, Nlrp3, Nlrc4, Nlrp1, foi analisada através de reações de PCR em tempo real, utilizando-se os sistemas SYBR Green em um aparelho GeneAmp 7700 (AppliedBiosystems, USA). Primers adequados para tais reações foram criados a partir do programa Primer Express (AppliedBiosystems) (Sequências especificas de cada primers estão dispostas em anexo).

\subsection{Quantificação de citocinas por ELISA.}

A presença de citocinas (IFN- $\gamma$, IL-10, TGF- $\beta$, IL-6, IL-17, IL-1 $\beta$, IL-18, IL22 e IL-23) nos tecidos pancreáticos e íleo foi analisada pelo método de ELISA. A quantificação foi realizada em homogeneizado dos tecidos em solução contendo inibidores de protease, utilizando kits específicos para tais dosagens, de acordo com as especificações do fabricante (Kits R\&D System). 


\subsection{Pré-tratamento com antibióticos.}

Um coquetel contendo Vancomicina (0,5g/L), Neomicina (1g/L), Metronidazol (1g/L) Ampicilina (1g/L) foi administrado por gavagem durante 21 dias em camundongos WT e AIM2-/- para induzir a depleção da microbiota.

\subsection{Permeabilidade intestinal pela análise de FITC-Dextran.}

Os camundongos, após 4 horas de jejum, foram tratados com fluoresceína isotiocianato (FITC)-Dextran por gavagem (200 mg/kg de peso corporal) (SigmaAldrich). O FITC-Dextran é uma macromolécula não metabolizada que pode ser utilizada como uma sonda de permeabilidade. Após 4 horas da administração do FITC-Dextran, o sangue total será coletado da ponta da veia da cauda e centrifugado à 2000 rpm por 3 minutos à temperatura ambiente. O soro foi coletado e diluições de FITC-Dextran em PBS foram usadas como curva padrão. A absorção de $50 \mu \mathrm{L}$ de soro ou de padrão foi medida em fluorímetro com excitação de $485 \mathrm{~nm}$ e a leitura em $535 \mathrm{~nm}$.

\subsection{Cultura de Macrófagos derivados da Medula óssea (BMMs) e leucócitos derivados do LNM e estímulo com DNA fecal}

A medula óssea dos grupos dos animais em estudo foi retirada dos fêmures utilizando-se $3 \mathrm{~mL}$ de meio RPMI incompleto. Após a homogeneização das células, $1,5 \mathrm{~mL}$ dessa suspensão foi adicionada em placas para a aderência das células (Optilux ${ }^{\mathrm{TM}}$, BD Biosciences) de dimensões $100 \times 20 \mathrm{~mm}$. Um volume de $10 \mathrm{~mL}$ de meio RPMI 10/30 (30ml de soro bovino fetal, 90mL de LCCM, 3ml de L-glutamina, 3ml de penincilina, e 174mL RPMI incompleto) de foi adicionado a essas placas. Essas células foram cultivadas na presença de $100 \mathrm{U} / \mathrm{mL}$ de penicilina e $100 \mu \mathrm{g} / \mathrm{mL}$ de estreptomicina, à $37^{\circ} \mathrm{C}$ em atmosfera umidificada contendo 5\% de CO2. Quatro dias depois foram acrescentados mais $10 \mathrm{~mL}$ de meio RPMI 10/5 (20mLde soro bovino fetal, 10mL de LCCM, $2 \mathrm{~mL}$ de L-glutamina, $2 \mathrm{~mL}$ de penicilina, e $166 \mathrm{~mL}$ RPMI incompleto) às placas. No sétimo dia de cultivo, as células foram removidas pela lavagem das monocamadas com PBS 
1X gelado, e a concentração celular acertada de acordo com o delineamento experimental. Essas células foram então estimuladas previamente com LPS $(50 \mu \mathrm{g})$ por 4 horas, e posteriormente estimuladas por 6 horas com Poly dA:dT $(1.5 \mu \mathrm{g} / \mathrm{mL})$ (agonista de AIM2), DNA fecal de animal controle $(1.5 \mu \mathrm{g} / \mathrm{mL})$ ou DNA fecal de animal diabético $(1.5 \mu \mathrm{g} / \mathrm{mL})$. Posteriormente, o sobrenadante foi coletado para a dosagem da citocina IL-1 $\beta$ pelo método de ELISA.

Para a cultura de leucócitos derivados dos LNM, foram coletados os LNM de camundongos WT e AIM2 ${ }^{-/}$controles ou diabéticos, e posteriormente processados em cell strainner, e lavados com $10 \mathrm{~mL}$ de RPMl contendo $5 \%$ de SBF. Em seguida as células foram contadas em câmara de neubauer, e ajustadas para uma concentração de $1 \times 10^{5}$ células $/ \mathrm{mL}$, que posteriormente foram colocadas em placa de 48 poços contendo meio RPMI $5 \%$ + estímulos (DNA fecal controle ou DNA fecal diabético) e logo em seguida colocadas em placas estufa de $\mathrm{CO}_{2}$ à $37^{\circ} \mathrm{C}$ por 17 horas. Após o período de incubação com o estímulo, as células foram coletadas, e estimuladas com PMA, ionomicina e brefeldina por 4 horas, e posteriormente marcadas com anticorpos conjugados à flourocromos específicos para CD3, CD4 e IL-17. Por fim, as células foram adquiridas em citometro de fluxo FACs Canto II, e analisadas no software Flowjo 7.

\subsection{Detecção da ativação de caspase-1 western blot}

Amostras de lisado do íleo de camundongos WT foram coletadas nos dias 0, 7 e 15 dias após a administração de STZ, assim como o sobrenadante da cultura de macrófagos derivados da medula óssea foi coletado após 6 horas, para análise de caspase-1 ativa por Western Blotting. As células remanescentes nos poços foram lisadas com tampão RIPA (10 mM Tris-HCl, pH 7.4, 1mM EDTA, $150 \mathrm{mMNaCl}, 1 \%$ Nonidet P-40, $1 \%$ deoxycholate, and $0.1 \%$ SDS) contendo um coquetel de inibidores de protease (Roche). Os lisados e sobrenadantes foram ressuspendidos em tampão de amostra contendo SDS (50 mM Tris; $\mathrm{pH}$ 6,8), 2\% SDS (USB Corporation, USA), 0,1\% azul de bromofenol (Synth, USA), 10\% glicerol (USB Corporation, USA), 2,5\% $\beta$-mercaptoetanol). As proteínas foram, então, transferidas para uma membrana de nitrocelulose (GE Healthcare, USA) utilizando o sistema de transferência SemidryTransferCell 
(Bio-RadLaboratories, USA) a 15 volts por 40 minutos. Neste sistema foi utilizado tampão de transferência (50 mM Tris, $40 \mathrm{mM}$ glicina e 10\% metanol). As membranas foram bloqueadas por 12 horas a $4^{\circ} \mathrm{C}$ em tampão Tris (TBS -Tris buffered saline) (25 mM Tris -Hexis Científica, BR, pH 7.4, 0,3 mMKCl -J.T. Backere140 mMNaCl-J.T. Bacher) contendo 0,1\% Tween-20 (TBS-T) e $5 \%$ de leite em pó desnatado. Após o bloqueio, as membranas foram incubadas com os anticorpos monoclonais anti-AIM2 (1:1000), anti-caspase-1 p20 (clone 4B4 -Genentech) (1:250), anti-IL-1ß p-17 (1:200) anti-IL-18 (1:200) (Sigma Aldrich) por 1 hora à temperatura ambiente. As membranas foram, então, lavadas em TBS-T e incubadas por 1 hora a 25 C com anticorpo secundário apropriado conjugado com peroxidase (diluição 1:3000; KPL, USA). Para a detecção das proteínas ligadas aos anticorpos específicos foi utilizado 0 reagente ECL luminol (GE Healthcare) e filme Hyperfilm (GE Healthcare).

\subsection{Imunofluorescência}

As amostras de íleo de camundongos WT e AIM2-- foram coletadas em tampão PBS Formol (4\%) e posteriormente processadas em micrótomo, e avaliadas a marcação com anticorpos primários anti-ZO-1 (1:50), anti-claudina2 (1:50) overnight e posteriormente lavadas, e marcadas com anticorpos secundários conjugados a fluorocromos Alexa 480 ou 594 por 2 horas. Em seguida, as imagens foram adquiridas em microscópio confocal leica SP5.

\subsection{Isolamento de células $T$ naïves por sorting e diferenciação para Th17 in vitro}

Foram coletados os baços e os linfonodos dos animais WT e Nlrp12-/, sendo os mesmos processados em uma cell strainer $(100 \mu \mathrm{m})$ com o auxílio de uma seringa de $3 \mathrm{ml}$, em RPMI-I. Foi adicionado tampão de lise (para lise de hemácias) e as células foram centrifugadas $\left(450 \mathrm{~g}, 8 \mathrm{~min}, 4^{\circ} \mathrm{C}\right)$. O sobrenadante foi descartado e as células foram ressuspendidas em RPMI-C, sendo colocadas em uma garrafa de cultura, e deixadas na estufa $\left(37^{\circ} \mathrm{C}, 5 \% \mathrm{CO} 2\right.$ e $8 \%$ de umidade por 30 minutos, para aderência de células aderentes, como macrófagos e células dendríticas). Posteriormente, as células foram centrifugadas e 
incubadas com o kit para separação de linfócitos T CD4+ por 10 minutos (CD4+ T Cell Isolation Kit - MiltenyiBiotec), que irá marcar células que não são CD4+, realizando assim uma seleção negativa dessas células, com posterior incubação com anticorpo anti-biotina por 10 minutos. Em seguida, as células foram centrifugadas, ressuspendidas em $500 \mu \mathrm{l}$ e levadas ao aparelho (AutoMacsproSeparator - MiltenyiBiotec), sendo utilizado o programa deplete. Após a obtenção dos linfócitos T CD4, estes foram centrifugados e marcados com o anticorpo anti-CD25 (aCD25-PE - BD Bioscience), por 10 minutos. Depois disso, as células foram centrifugadas e incubadas sob as mesmas condições descritas acima com o anticorpo Anti-PE (MiltenyiBiotec). As células foram centrifugadas e ressuspendidas em $500 \mu \mathrm{l}$ para separação no AutoMacs (posseldprogram). Após a separação, foi realizada a marcação com anticorpo anti-CD4, para avaliar a qualidade da separação por citometria de fluxo. Em todos os experimentos a pureza de linfócitos T CD4+ foi maior que $90 \%$. Todas as incubações foram realizadas a $4^{\circ} \mathrm{C}$, com as amostras protegidas da luz. Após isso, as células foram deixadas em cultura em RPMI-C (10\% de soro bovino fetal, $200 \mathrm{mM}$ de glutamina, 10.000 unidades de penicilina, $10 \mathrm{mg} / \mathrm{ml}$ de estreptomicina, $250 \mu \mathrm{g} / \mathrm{ml}$ de anfotericina $\mathrm{B}$ e $275 \mathrm{nM}$ de $\beta$-mercaptoetanol), com estímulos de proliferação (anti-CD3 e anti-CD28 BD Biosciences $-1 \mu \mathrm{g} / \mathrm{ml}$ ) durante 96 horas, sob $37^{\circ} \mathrm{C}, 5 \%$ de $\mathrm{CO} 2$, em condições polarizantes para a diferenciação de linfócitos Th17 (2,5 ng/ml de TGF- $\beta$ e $20 \mathrm{ng} / \mathrm{ml}$ de IL-6). Posteriormente, foi realizado o protocolo de marcação intracelular para IL-17A e IL-22 sendo os resultados obtidos por citometria de fluxo (FACs Canto II).

\subsection{Forma de analises dos resultados}

As análises dos resultados foram expressos como média \pm desvio padrão (DP) e os seguintes testes estatísticos foram realizados: Teste one-wayANOVA seguido pelo pós-teste de Tukey, ou test t seguida pelo pós-teste Mann-Whitney. Tais análises foram realizadas através do software GraphPad Prism (GraphPad Software Inc., San Diego CA, EUA) e foram consideradas estatisticamente significativas as diferenças que apresentaram valores de $p$ igual ou inferior a 0.05 . 
4. Resultados 


\subsection{O receptor AIM2 é ativado nos LNPs e mucosa intestinal durante o DM1}

Inicialmente, experimentos foram realizados a fim de investigar a expressão genica e proteica, assim como a ativação do receptor AIM2 durante 0 desenvolvimento do DM1. Para isso, camundongos da linhagem C57BL/6 selvagens foram tratados com 5 doses consecutivas de estreptozotocina (40mg/Kg/dia) e avaliados quanto à expressão do receptor AIM2 e de moléculas relacionadas à sua via de ativação nos LNP e intestino (íleo).

Nossos resultados demonstram aumento significativo da expressão gênica de AIM2 nos LNP após 7 e 15 dias do tratamento com STZ (Figura 1A). Corroborando, também notamos aumento significativo da expressão gênica e proteica de IL-18 após 7 e 15 dias da indução da doença nos LNPs e tecido pancreático, respectivamente (Figuras 1B, C). De maneira interessante, também observou-se um aumento significativo da expressão gênica e proteica do receptor AIM2 no íleo após 7 dias (Figuras 1D, I), assim como da enzima prócaspase-1 e caspase-1 ativa (Figura 1H) e das citocinas pró-IL-1 $\beta$ e pró- IL-18 (Figura 1E, F).

Desta forma, estes dados sugerem que o receptor AIM2 é expresso e ativado nos linfonodos drenantes do pâncreas e na mucosa intestinal durante os estágios iniciais do desenvolvimento do DM1. 
Linfonodos Pancreáticos/Pâncreas
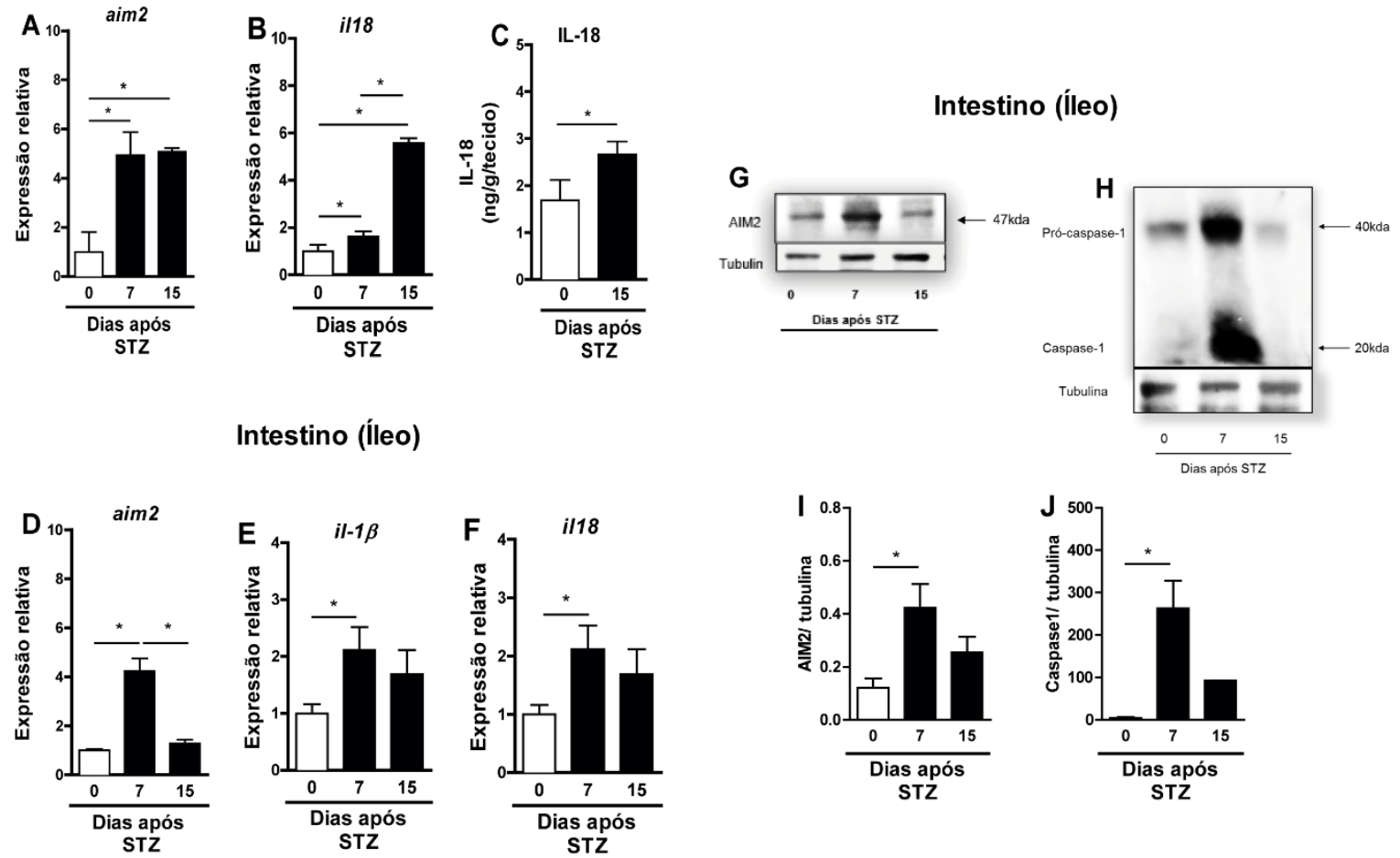

Figura 1 - O receptor AIM2 é ativado nos LNP e íleo durante o DM1; (A, B) Expressão gênica do receptor AIM2 e da citocina IL-18 nos LNP de camundongos WT 0, 7 e 15 dias após a administração de STZ; (C) Dosagem da citocina IL-18 no pâncreas de camundongos WT 15 dias após a administração de STZ por ELISA; (D, E, F) Cinética da expressão gênica do receptor AIM2, pró-IL-1 $1 \beta$ e pró-IL-18 no íleo de camundongos WT após a indução de STZ; (G, H, I, J) Cinética da expressão protéica por western blot de AIM2, pró-caspase-1, caspase-1 ativa no íleo de camundongos WT; 


\subsection{A ativação do receptor AIM2 contribui para a proteção ao DM1}

Como foi verificado aumento da expressão do receptor AIM2 nos estágios iniciais do DM1, nosso próximo passo foi investigar como a deficiência deste receptor poderia influenciar o desenvolvimento do DM1. Para isso, camundongos WT e deficientes para AIM2 $\left(\mathrm{AIM2}^{-1}\right)$ foram submetidos ao esquema de tratamento com STZ, e após 15 dias foram avaliados os parâmetros clínicos relacionados a progressão do DM1, tais como a incidência da doença, hiperglicemia, níveis séricos de insulina e análise histopatológica das ilhotas pancreáticas.

Notavelmente, camundongos $\mathrm{AIM}^{-/-}$tornaram-se suscetíveis ao DM1 induzido quimicamente com STZ (Figura 2A), uma vez que 100\% dos animais AIM2 $^{-1}$ desenvolveram a doença após a administração de STZ, comparado com um percentual de $40 \%$ e $80 \%$ dos camundongos WT após 7 e 15 dias da administração de STZ. Os níveis de glicemia dos camundongos AIM2 ${ }^{-/-}$foram significativamente elevados quando comparados com os animais WT e AIM2---, tratados como veículo ou STZ, ultrapassando $400 \mathrm{mg} / \mathrm{dL}$ de glicemia (Figuras 2B, C, D. Ainda, foi detectado redução dos níveis séricos de insulina nos animais WT ou deficientes de AIM2 comparado aqueles WT com VH, (Figura 2E).

Em seguida, avaliamos o infiltrado inflamatório nas ilhotas pancreáticas denominado de insulite. Não observamos a presença de infiltrado inflamatório nas ilhotas pancreáticas de camundongos WT e AIM2 ${ }^{-/}$não diabéticos (Figura 2F, G). Todavia, camundongos WT e AIM2 $2^{-/}$tratados com STZ apresentaram acentuado infiltrado inflamatório nas ilhotas pancreáticas (Figura 2F, G), sendo caracterizado como peri-insulite e insulite invasiva. Por fim, foi avaliada a marcação de insulina por imunohistoquímica nas ilhotas pancreáticas. Os dados demonstraram que camundongos WT e AIM2 $2^{-1-}$ não diabéticos apresentaram uma intensa marcação de insulina nas ilhotas pancreáticas. Contudo, nossos dados demonstram uma redução da expressão de insulina nas ilhotas pancreáticas de camundongos WT e AIM2-- após 15 dias do tratamento com STZ (Figura 2G).

Em conjunto, estes resultados indicam um efeito protetor do receptor AIM2 contra o desenvolvimento do DM1. 

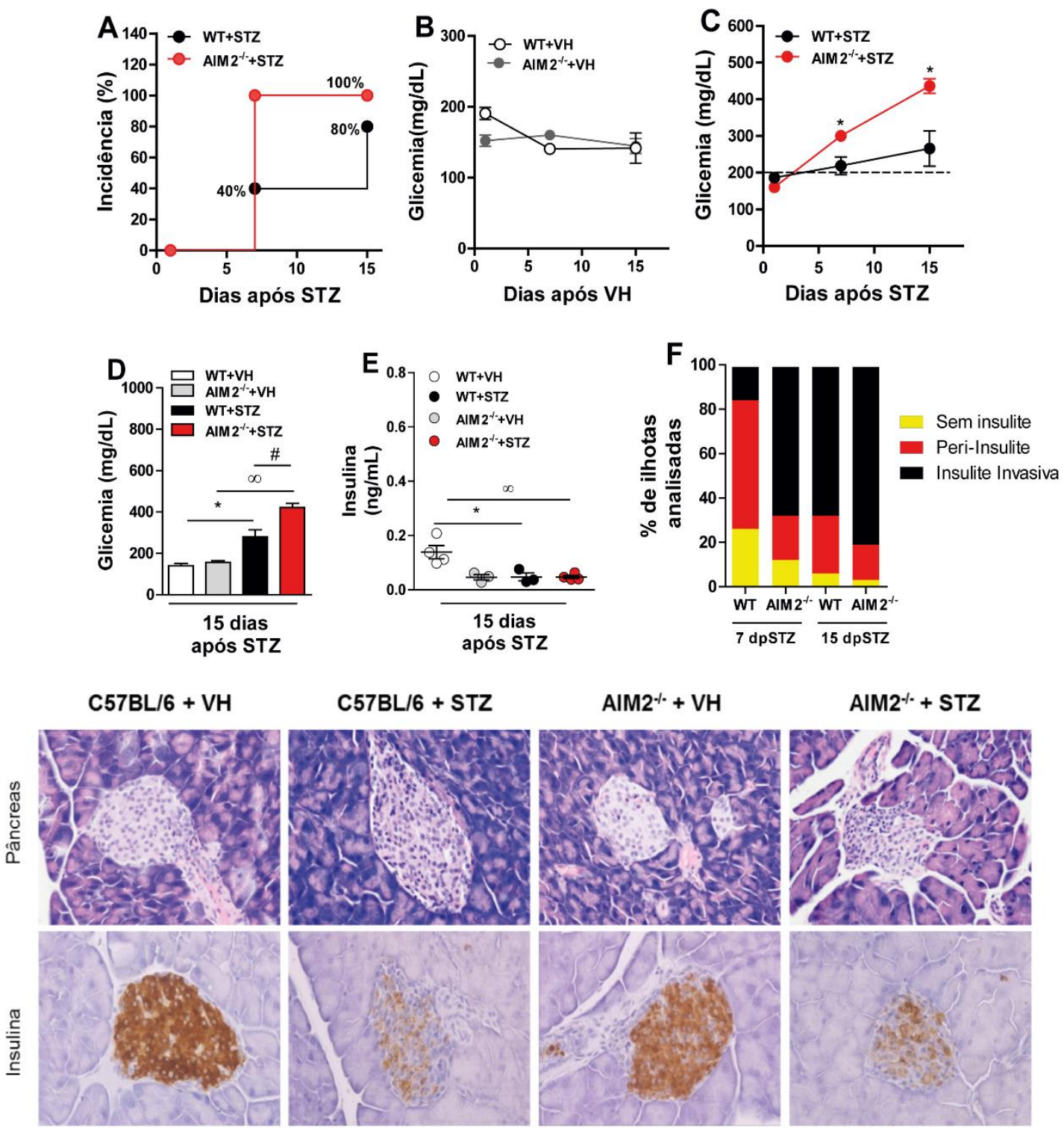

Figura 2 - A deficiência de AIM2 confere suscetibilidade ao DM1; (A) Incidência de diabetes em camundongos WT e AIM2 ${ }^{-/-1}$ 1, 7 e 15 dias após a administração de STZ; (B, C) Cinética dos níveis de glicose sanguínea em camundongos WT e AIM2 $2^{-1-1,7}$ e 15 dias após a administração de STZ; (D, E) Níveis de glicose e insulina sanguínea em camundongos WT e AIM2-/- 15 dias após a administração de STZ; $(\mathbf{F}, \mathbf{G})$ Análise histopatológica e marcação de imunohistoquímica para insulina no tecido pancreático de camundongos WT e AIM2 $2^{-1-} 15$ dias após a administração de STZ. 


\subsection{A ativação do receptor AIM2 controla à translocação de bactérias da microbiota intestinal para os LNPs durante o DM1}

Recentemente, nosso grupo de pesquisa demonstrou que um estado de disbiose intestinal está associado com a translocação de bactérias da microbiota para os LNP, o que leva a ativação do receptor NOD2, e contribui para o início do DM1 (COSTA et al., 2016). Neste contexto, buscamos averiguar se ativação de AIM2 poderia exercer uma função no controle da translocação bacteriana para os LNP.

Para testar esta hipótese, avaliamos através da quantificação de UFC (Unidades formadoras de colônias) e da expressão do gene bacteriano 16S, o perfil de translocação bacteriana para os LNPs de camundongos WT e AIM2-controles e tratados com STZ. De maneira interessante, detectamos uma elevada translocação bacteriana nos LNPs de camundongos AIM2 $2^{-/}$quando comparados aos WT após 7 e 15 dias da administração de STZ (Figura 3A). De forma semelhante, observamos maior expressão gênica do gene bacteriano $16 \mathrm{~S}$ nos LNPs, mas não nos LMN, em camundongosAIM2 comparados aos WT após 15 dias da indução de STZ (Figura 3B, C).

Posteriormente, avaliamos o perfil de bactérias da microbiota intestinal presente nos LNPs de camundongos WT e $\mathrm{AIM}^{-/}$controles e diabéticos. Camundongos AIM2$^{-/}$diabéticos possuem um aumento de bactérias do filo Bacteroidetes e Firmicutes nos LNPs e fezes quando comparado com animais WT diabéticos (Figura 3D, E, I, J, N). No entanto, não observamos diferenças na translocação de bactérias do filo Proteobactéria para os LNPs, contudo, a expressão de bactérias deste filo está significativamente diminuída nas fezes de camundongos AIM2-- diabéticos (Figura 3F, K, N). Tal fenômeno também foi observado com bactérias do filo Verrucomicrobia, porém de forma inversa, camundongos $\mathrm{AlM}^{-/}$- diabéticos possuem um significativo aumento de bactérias deste filo nas fezes (Figura $\mathbf{3 H}, \mathbf{M}, \mathbf{N}$ ). No que tange o filo Actinobactéria, observamos significativa diminuição de bactérias deste filo nos LNPs e aumento nas fezes destes animais (Figuras $\mathbf{3 G}, \mathbf{L}, \mathbf{N}$ ).

Por fim, para confirmar o envolvimento da microbiota na suscetibilidade ao DM1 em camundongos $\mathrm{AIM}^{--/}$realizamos um tratamento com um coquetel de antibióticos de amplo espectro contendo metronidazol, ampicilina, 
vancomicina e neomicina, a fim de depletar a microbiota de camundongos WT e

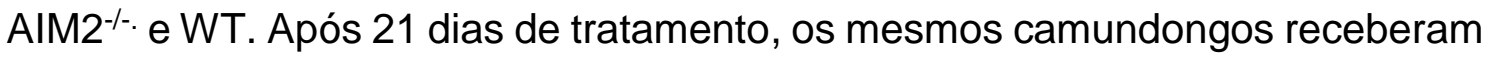
injeções de STZ e 15 dias após avaliamos os níveis sanguíneos de glicemia. De maneira interessante, ambos os camundongos WT e AIM2-- que receberam o tratamento com antibióticos e posteriormente STZ não desenvolveram diabetes apresentando glicemia inferior à $200 \mathrm{mg} / \mathrm{dL}$ quando comparados com os animais que receberam apenas o tratamento com STZ (Figura 30). Tais resultados confirmam o envolvimento da microbiota intestinal no desenvolvimento do DM1, assim como a importância do inflamassoma AIM2 em minimizar a disbiose intestinal e atenuar a translocação de bactérias da microbiota para os LNPs.

De forma geral, estes resultados demonstram que a ativação do inflamassoma AIM2 na mucosa intestinal controla a disbiose intestinal e retarda a translocação bacteriana para os LNPs e dessa forma, contribui para a proteção ao desenvolvimento do DM1. 

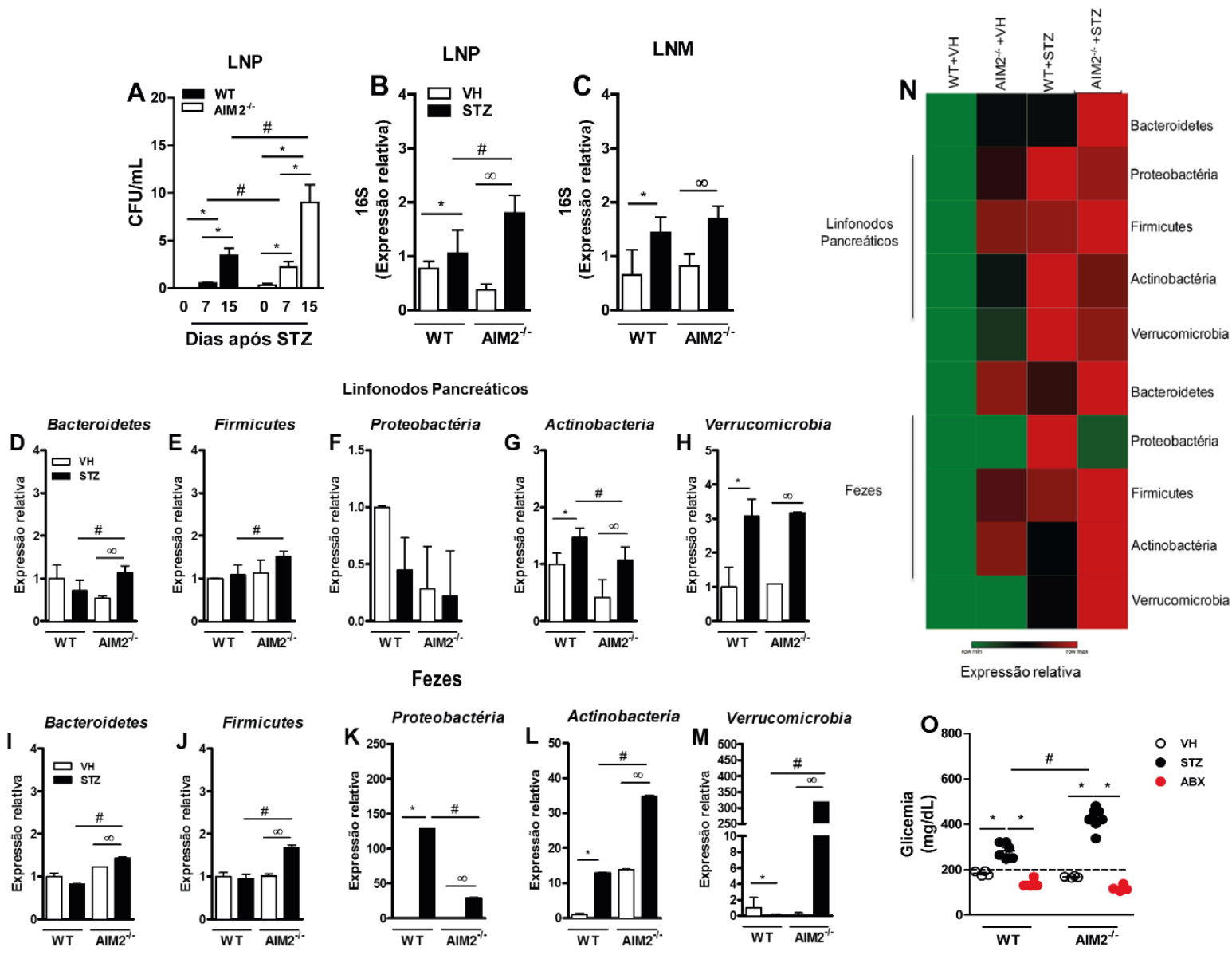

Figura 3 - A ativação de AIM2 controla a disbiose intestinal e a translocação bacteriana para os LNP durante o DM1; (A) Cinética de UFC/mL provenientes de suspensão de células dos LNP de camundongos WT e AIM2-- naives ou diabéticos; (B, C) Expressão gênica do gene $16 \mathrm{~S}$ nos LNPs e LMNs de camundongos WT e AIM2-- naives ou diabéticos; (D-N) Expressão gênica de bactérias dos filos Bacteroidetes, Firmicutes, Proteobactéria, Actinobactéria e Verrucomicrobia nos LNP e fezes de camundongos WT e AIM2 ${ }^{-/}$controles ou diabéticos; ( 0 ) Níveis de glicose sanguínea camundongos WT e $\mathrm{AIM}^{-1-}$ controles ou diabéticos após tratamento com STZ com ou sem tratamento prévio com coquetel de antibiótico (ABX). 


\subsection{A ativação do receptor AIM2 regula a expressão de proteínas de junção e a permeabilidade intestinal durante o DM1.}

Conforme observado nos resultados anteriores, a deficiência do inflamassoma AIM2 proporciona um aumento na translocação de bactérias da microbiota intestinal para os LNP e contribui para o início do DM1. Sabe-se que um aumento da permeabilidade intestinal causada por alterações na expressão de proteínas de junção celular (Tight junction proteins) está associado com a translocação de bactérias do lúmen intestinal para a lâmina própria (LP)(ARRIETA et al., 2006). Com base nestas evidências, nosso próximo passo foi avaliar possíveis alterações da permeabilidade intestinal em camundongos WT e AIM2-/- controles e diabéticos, que poderiam estar relacionadas com uma maior translocação de bactérias da microbiota para os LNPs e consequente suscetibilidade ao DM1.

Inicialmente, objetivando avaliar se a deficiência de $\mathrm{AIM} 2^{-/-}$exerce influência na permeabilidade intestinal realizamos o ensaio de administração de FITC dextran. Apesar de não ser significativo, observamos um proeminente aumento da concentração de FITC-dextran no soro de camundongos $\mathrm{AIM}^{-/-}$ diabéticos quando comparado aos camundongos WT diabéticos (Figura 4A). Porém, este dado sugere que camundongos $\mathrm{AIM}^{-/-}$apresentam uma permeabilidade intestinal aumentada durante o DM1, o que nos levou a explorar a expressão gênica e proteica de algumas proteínas de junção relacionadas com a manutenção da permeabilidade e integridade da barreira intestinal, como ZO1, claudina-2 e ocludina.

De fato, camundongos $\mathrm{AlM}^{-/-}$diabéticos possuem uma diminuição significativa na expressão gênica da proteína de junção ZO-1 no íleo 7 e 15 dias após a administração de STZ, quando comparados com camundongos WT (Figura 4B). Tal expressão foi confirmada através de marcação de imunofluorescência da proteína ZO-1, onde foi observada reduzida marcação no íleo de camundongos AIM2-/- 7 dias após a administração de STZ (Figura 4E). Não obstante, a expressão da proteína de junção ocludina mostrou-se significativamente aumentada no $7^{\circ}$ dia após a administração de STZ no íleo de camundongos $\mathrm{AIM}^{-1}$, mas diminuiu no íleo de camundongos WT e AIM2 ${ }^{-/}$após esse período (Figura 4D). Por outro lado, camundongos $\mathrm{AIM}^{-/-}$apresentaram 
um significativo aumento na expressão gênica de claudina-2 no íleo 7 dias após a administração de STZ. Tal expressão foi discretamente observada no íleo de camundongos WT submetidos ao tratamento de STZ (Figura 4C). Da mesma forma, observamos um aumento acentuado na marcação de claudina-2 por imunofluorescência no íleo de camundongos $\mathrm{AIM}^{-{ }^{-}}$no $7^{\circ}$ dia após a administração de STZ comparado ao íleo de camundongos WT (Figura 4F).

Com base nestes dados, concluímos que a ativação do receptor AIM2 na mucosa intestinal parece regular de forma direta ou indireta a expressão de proteínas de junção, o que proporciona uma menor permeabilidade intestinal e consequente controle da translocação bacteriana para os LNPs. 

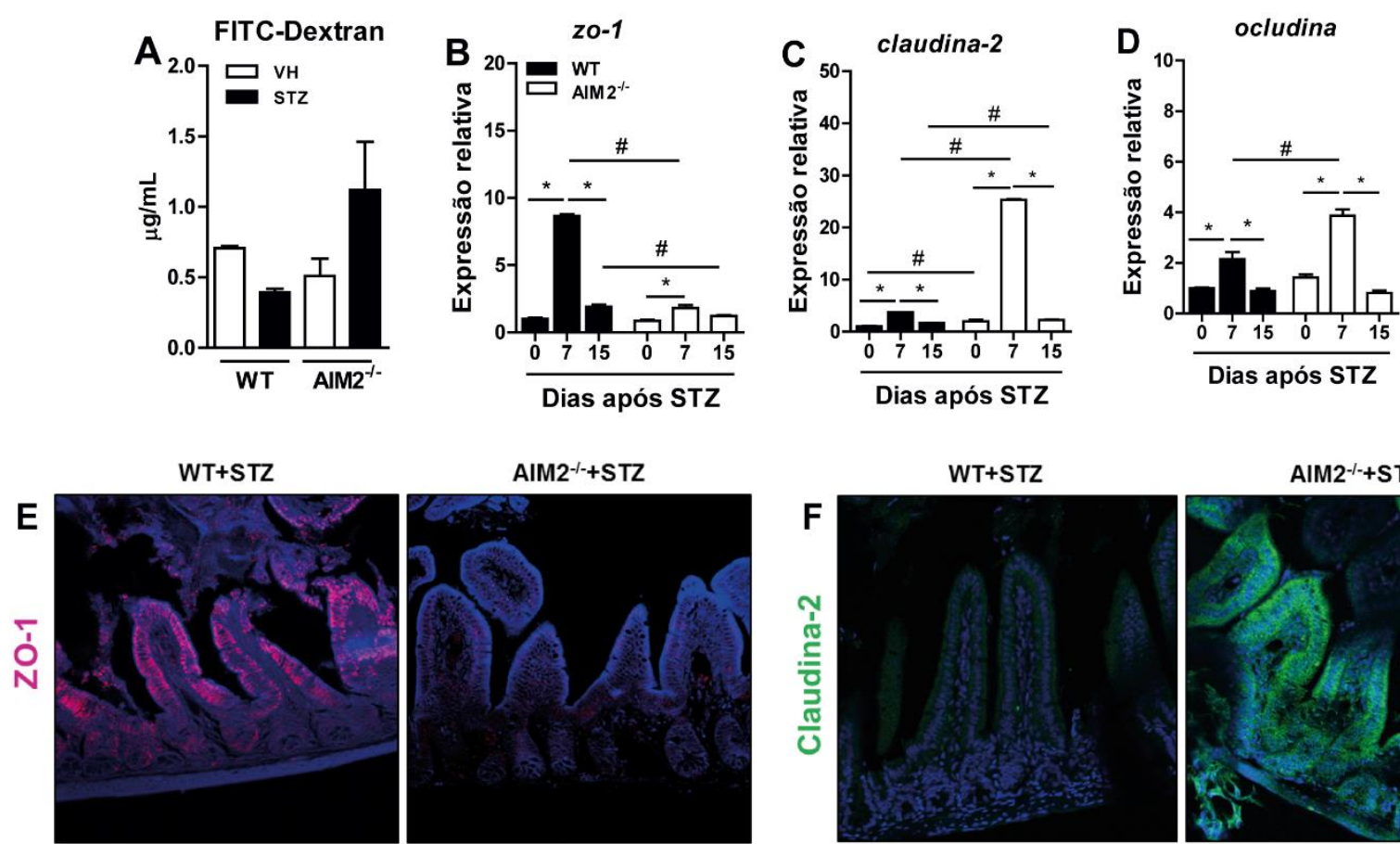

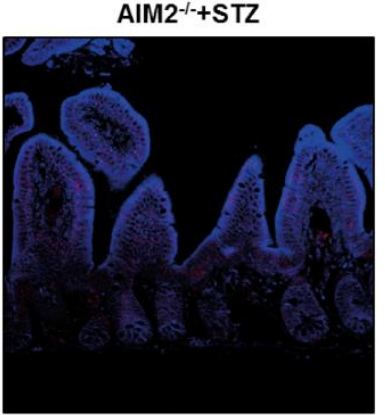

7 dias após administração de STZ

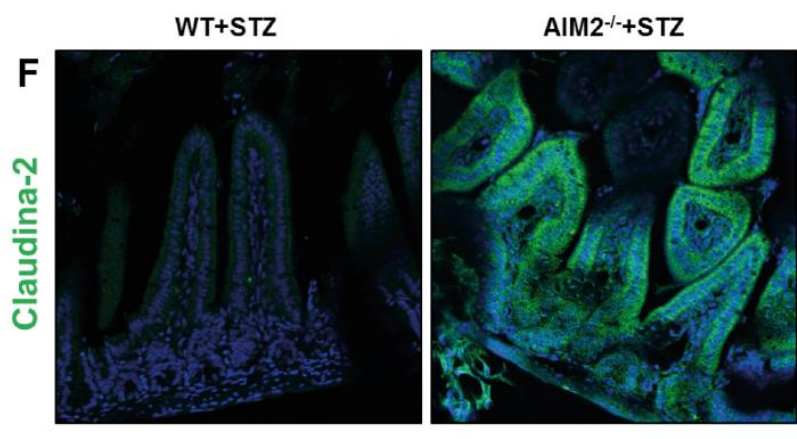

7 dias após administração de STZ

Figura 4 - A ativação do receptor AIM2 regula a expressão de proteínas de junção celular no epitélio intestinal. (A) Níveis séricos de FITC-Dextran no soro de camundongos WT e AIM2 ${ }^{-/}$controles e diabéticos; (B, C, D) Expressão gênica de ZO-1, ocludina e claudina2 no íleo de camundongos WT e AIM2 ${ }^{-/}$após a administração de STZ; (E, F) Microscopia de imunofluorescência representando a expressão proteica de ZO-1 e claudina-2 no íleo de camundongos WT e AIM2 ${ }^{--}$após a administração de STZ. 
4.5. A ativação do receptor AIM2 regula a expressão de IL-18, IL-22, peptídeos antimicrobianos e produção de muco na mucosa intestinal.

Estudos recentes têm demonstrado uma importante função de citocinas derivadas da ativação do complexo inflamassoma, como a IL-18, por exemplo, na manutenção da integridade intestinal. Esta citocina parece ter um papel central na produção de peptídeos antimicrobianos através da regulação da produção de IL-22 na mucosa intestinal, o que previne processos de disbiose intestinal (RATSIMANDRESY et al., 2017). Com base nessas evidências, buscamos avaliar se a deficiência de AIM2 altera a expressão gênica de IL-18 e IL-22, assim como isso poderia influenciar a expressão de peptídeos antimicrobianos e produção de mucinas no intestino durante o DM1.

Ao avaliar a expressão de tais moléculas no íleo de camundongos WT ou deficientes do receptor AIM2 diabéticos e não diabéticos, observamos que a deficiência de AIM2 está relacionada com uma menor expressão de IL-18 e IL22 no íleo 15 e 7 dias após a administração de STZ, quando comparados aos camundongos WT (Figura 5A, B). Entretanto, camundongos AIM2-apresentaram um aumento da defensinaDefcr1 e diminuição significativa do peptídeo antimicrobiano Regllly no íleo 15 dias após a administração de STZ quando comparados com camundongos WT (Figura 5C, D).

Por fim, avaliamos a expressão gênica de mucinas, que são proteínas que regulam a produção de muco por células caliciformes. A produção de muco é de suma importância para formar uma barreira química e impedir a colonização de bactérias na lâmina própria(PELASEYED et al., 2014). Verificamos que camundongos $\mathrm{AIM}^{-1-}$ diabéticos possuem uma diminuição significativa na expressão gênica da mucina 2 no íleo 15 dias após a administração de STZ, assim como uma redução na marcação de muco no intestino quando comparados com camundongos WT (Figuras 5E, F, G).

Em suma, estes dados mostram que a ativação do receptor AIM2 parece regular a expressão de IL-18 e IL-22, assim como a produção de peptídeos antimicrobianos e muco no íleo, como forma de prevenir o processo de disbiose intestinal e translocação bacteriana durante o DM1. 

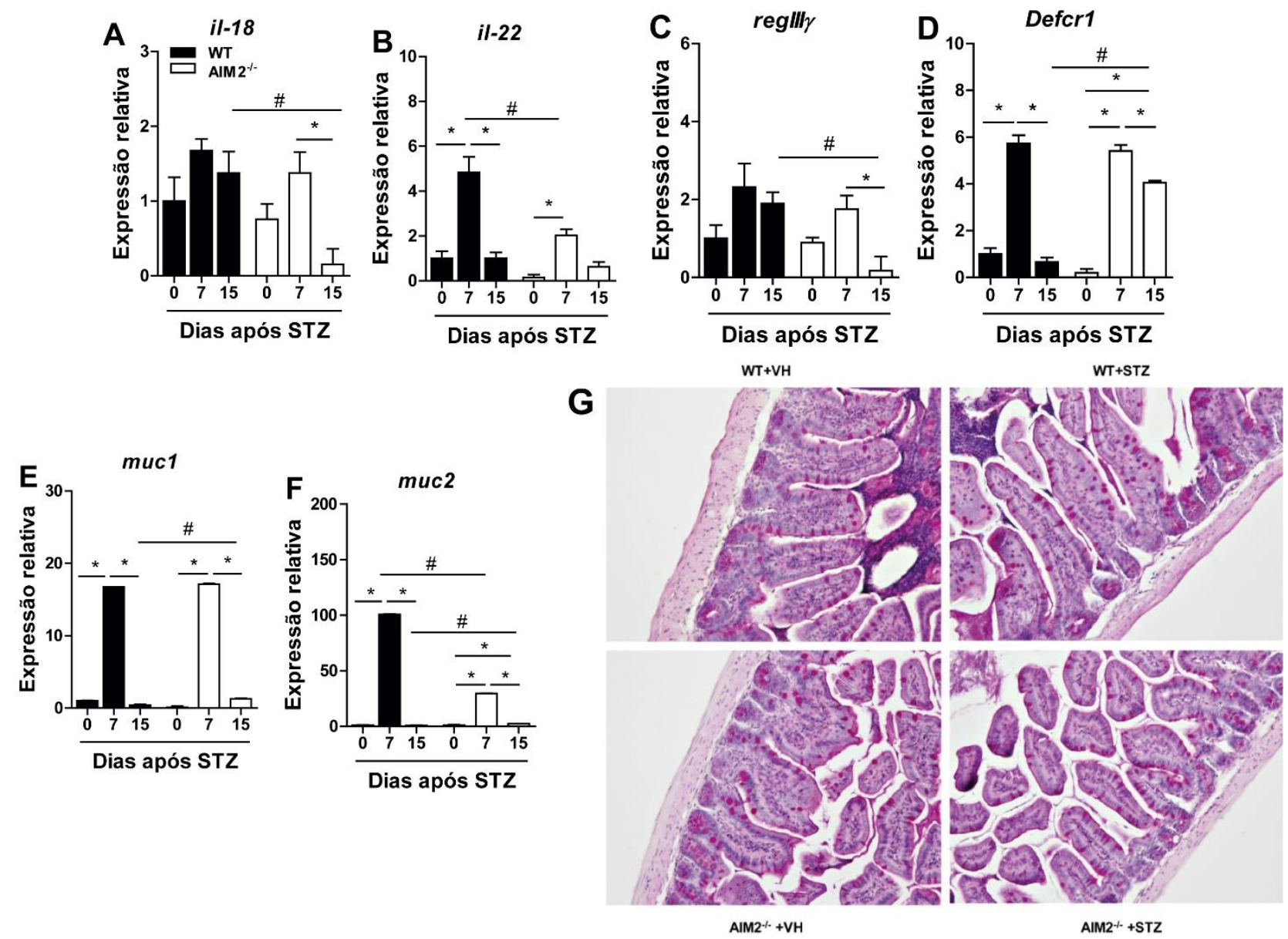

Figura 5 - A ativação do receptor AIM2 regula à expressão gênica das citocinas IL-18, IL-22, defensinas, peptídeos antimicrobianos e mucinas no íleo (A-F) Cinética da expressão gênica de IL-18, IL-22, Regllly, Defcr1, Muc1, Muc2 no íleo de camundongos WT e $\mathrm{AIM}^{-/-}$controles ou diabéticos; (G) Coloração de PSA para marcação de muco no íleo de camundongos WT e AIM2 ${ }^{-/}$controles ou diabéticos. 


\subsection{O inflamassoma AIM2 é ativado em macrófagos em resposta ao DNA de bactérias da microbiota em disbiose.}

Nossos resultados demonstraram até o momento que o inflamassoma AIM2 parece ter um papel central na regulação da homeostase intestinal e controle da translocação bacteriana para os LNPs, isto possivelmente pode ser atribuído ao seu papel no controle do desenvolvimento do DM1. Devido a redução da expressão gênica de IL-18 observada no íleo de camundongos AIM21- durante o DM1, a próxima etapa foi avaliar se o receptor AIM2 pode ser ativado in vitro por DNA isolado das fezes de camundongos controles e diabéticos e estimular a produção de citocinas derivadas da ativação do inflamassoma, tais como, IL-1 $\beta$ e IL-18.

Inicialmente buscamos testar se o DNA de uma microbiota normal ou em disbiose (isolado das fezes um animal diabético) é capaz de ativar e se colocalizar com o AIM2 em macrófagos AIM2 citrina. Para isso, transfectamos em macrófagos AIM2 citrina Poly dA dT (agonista de AIM2), DNA fecal controle (DNA de microbiota normal) e DNA Fecal Diabético (DNA de microbiota em disbiose) e avaliamos por meio de microscopia confocal de imunofluorescência a ativação e a colocalização dos respectivos estímulos com o receptor AIM2. Não observamos a ativação do receptor AIM2 em macrófagos que não receberam estímulos, por outro lado macrófagos estimulados com Poly dA dT e DNA fecal diabético apresentaram ativação do receptor AIM2 e colocalização do DNA com o AIM2, 2 horas após o estímulo. Contudo, não foi observada a ativação por DNA fecal de uma microbiota normal (Figura 6A).

Em seguida, para melhor compreender se o receptor AIM2 é ativado em resposta ao DNA de uma microbiota em disbiose, foram utilizados macrófagos derivados da medula óssea (BMDM) WT e AIM2 $2^{-/-}$a fim de avaliar a ativação do inflamassoma AIM2. Os nossos dados demonstraram uma alta produção de IL$1 \beta$ por macrófagos WT estimulados com DNA fecal diabético, quando comparado à macrófagos WT que receberam o DNA fecal controle. Não obstante, os níveis de IL-1 $\beta$ foram ainda maiores, quando os macrófagos WT foram primados com LPS e posteriormente transfectados com DNA fecal em disbiose. Adicionalmente, não foram detectados níveis de IL-1 $\beta$ nas culturas de macrófagos deficientes para AIM2 após a estimulação (Figura 6B). 
Desta forma, estes resultados inferem o DNA de uma microbiota em disbiose é capaz de induzir a ativação do inflamassoma AIM2 e subsequente produção de IL-1ß. 

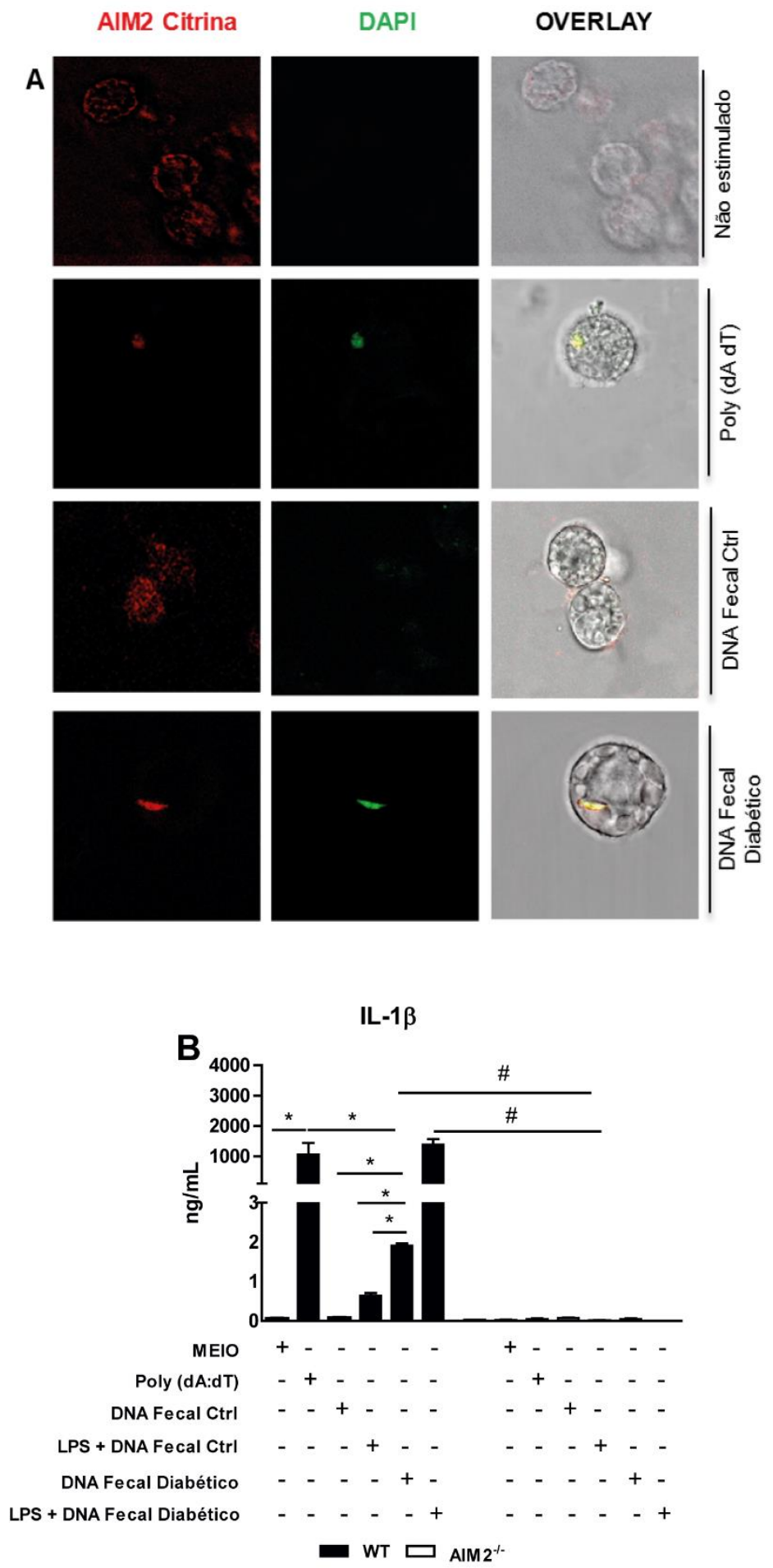

Figura 6 - O DNA de bactérias da microbiota em disbiose ativa o inflamassoma AIM2 em macrófagos in vitro (A) Imunoflourêscencia de macrófagos AIM2 citrina estimulados com Meio, Poly (dA:dT) $(1.5 \mu \mathrm{g} / \mathrm{mL})$, DNA fecal controle $(1.5 \mu \mathrm{g} / \mathrm{mL})$, e DNA fecal diabético (1.5 $\mathrm{\mu g} / \mathrm{mL})$; (B) Níveis da citocina IL-1 $\beta$ no sobrenadante da cultura de macrófagos derivados da medula óssea de camundongos WT e AIM2 ${ }^{-/-}$com Meio, Poly (dA:dT) (1.5 $\mu \mathrm{g} / \mathrm{mL})$, DNA fecal controle (1.5 $\mu \mathrm{g} / \mathrm{mL})$ e DNA fecal diabético $(1.5 \mu \mathrm{g} / \mathrm{mL})$, primados ou não com $50 \mu \mathrm{g} / \mathrm{mL}$ de LPS. 


\subsection{A ativação do inflamassoma AIM2 por DNA de uma microbiota em disbiose aumenta expansão de linfócitos Th17 in vitro.}

Linfócitos Th17 possuem um papel fundamental na manutenção da homeostase intestinal durante processos de disbiose, controlando a permeabilidade intestinal e induzindo o recrutamento de neutrófilos, o que proporciona o controle da translocação de bactérias da microbiota do lúmen intestinal para a lâmina própria (AUJLA et al., 2007). Com base nas observações do resultado anterior, em que a ativação de AIM2 em macrófagos por DNA fecal de uma microbiota em disbiose aumenta a produção de IL-1 $\beta$, buscamos avaliar como a produção desta citocina poderia influenciar na expansão de linfócitos Th17 in vitro derivados da mucosa intestinal, uma vez que esta citocina apresenta um importante papel após a diferenciação deste subtipo celular, induzindo sua expansão no local de inflamação.

Com o objetivo de averiguar se a ativação de AIM2 e consequente produção de IL-1 $\beta$ altera a expansão de linfócitos Th17, isolamos leucócitos totais dos LNMs de camundongos WT e AIM2-/-, controles ou diabéticos, após 7 dias do tratamento com STZ. Posteriormente estes foram transfectados, ou não, com DNA das fezes de camundongos controles (microbiota normal) ou diabéticos (microbiota em disbiose) e colocados em cultura por 17 horas. Em seguida, as células totais foram estimuladas com PMA e ionomicina para marcação intracelular de IL-17, e posteriormente adquiridas e analisadas por citometria de fluxo.

De maneira interessante, observamos um aumento significativo na porcentagem (\%) de células $\mathrm{CD} 4^{+} \mathrm{IL}-17^{+}$(Th17) em cultura de leucócitos de camundongos WT diabéticos, 7 dias após a administração de STZ, incubados com meio, quando comparado aqueles de camundongos controles ou deficientes de AIM2. Contudo, não foi observado aumento da população de linfócitos Th17 quando tais leucócitos foram estimulados com o DNA fecal de uma microbiota normal. Porém, quando leucócitos totais (WT) foram estimulados com o DNA isolado de uma microbiota em disbiose observou-se um significante aumento da população de linfócitos Th17, enquanto que essa população mostrou-se reduzida em camundongos deficientes de AIM2. Tais dados indicam que ativação de AIM2 em leucócitos, presentes nos LMN, poderia estar influenciando 
na expansão de linfócitos Th17 após reestimulo in vitro com o DNA de uma microbiota em disbiose, mimetizando o que estaria acontecendo in vivo (Figura 7A, B). 


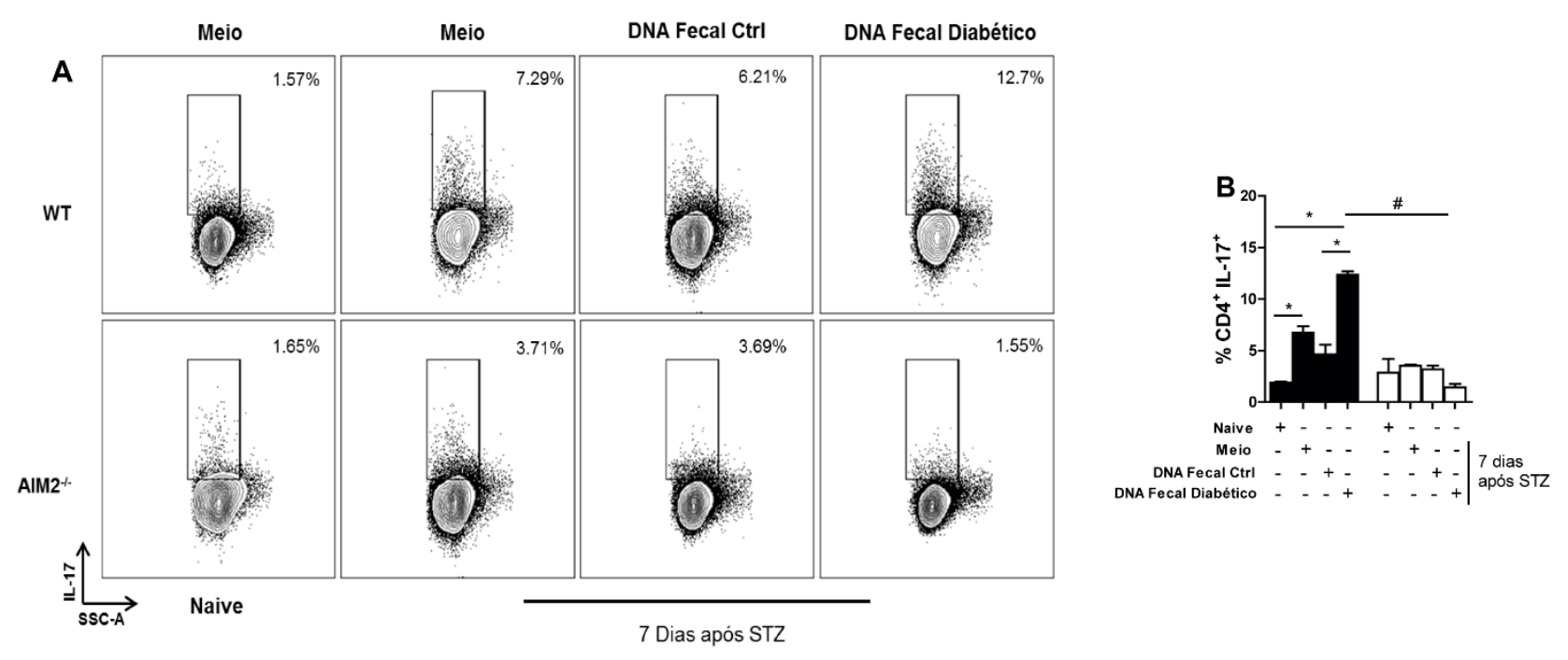

Figura 7 - A ativação do receptor AIM2 por DNA fecal em disbiose aumenta a expansão de linfócitos Th17 derivados do LNM após reestimulo in vitro (A) Dotplot de leucócitos derivados dos LNM de camundongos WT e AIM2 $2^{-/-}$controles ou diabéticos reestimulados ou não com DNA fecal controle ou do diabético; (B, C) Porcentagem de linfócitos Th17 marcados à partir de leucócitos derivados dos LNM de camundongos WT e $\mathrm{AIM}^{-/-}$controles ou diabéticos reestimulados ou não com DNA fecal controle ou do diabético. 


\section{8. $O$ receptor AIM2 atua como um regulador positivo durante a}

diferenciação de linfócitos Th17.

De acordo com o resultado anterior, camundongos $\mathrm{AlM}^{-/}$diabéticos apresentaram uma redução na porcentagem de linfócitos Th17 em comparação com os camundongos WT. Com isso, nosso próximo objetivo foi entender se a ausência de AIM2 estaria influenciando na a indução de linfócitos Th17 devido à baixa produção de IL-1 $\beta$, fator essencial para a expansão de tais células, ou se a deficiência intrínseca deste receptor no próprio linfócito $T$ já é suficiente para comprometer sua diferenciação.

Para testar tal hipótese, isolamos linfócitos T CD4 naives do baço e linfonodos drenantes de camundongos WT e AIM2, e posteriormente os mesmos foram colocados em cultura sob condições polarizantes para o perfil Th17 ( $\alpha \mathrm{CD} 3, \alpha C D 28$, TGF $\beta$ e IL-6) e após 72 horas de cultura, tais células foram coletadas e avaliadas quanto à expressão de citocinas do perfil Th17 (IL-17 e IL22) por citometria de fluxo, assim como a expressão gênica do RORC, que codifica a expressão do fator de transcrição ROR- $\gamma$ t responsável pela diferenciação destas células.

De maneira interessante, observamos que linfócitos T CD4 deficientes de AIM2 possuem uma diferenciação prejudicada para o perfil Th17, assim como uma baixa expressão do gene do fator de transcrição rorc, e da citocina II-17 quando comparados com linfócitos T CD4 WT (Figura 8A, B, D, E). Não obstante, linfócitos Th17 deficientes para AIM2 parecem produzir mais IL-22, quando comparados com linfócitos Th17 WT (Figura 8A, C, F).

Desta forma, estes dados sugerem que além de ter um papel importante em células mieloides através da produção de IL-1 $\beta$ e consequente expansão de linfócitos Th17, o receptor AIM2 parece participar de forma direta da diferenciação das células Th17, atuando como um regulador positivo na produção de IL-17 e negativo na produção de IL-22 por este subtipo celular. 

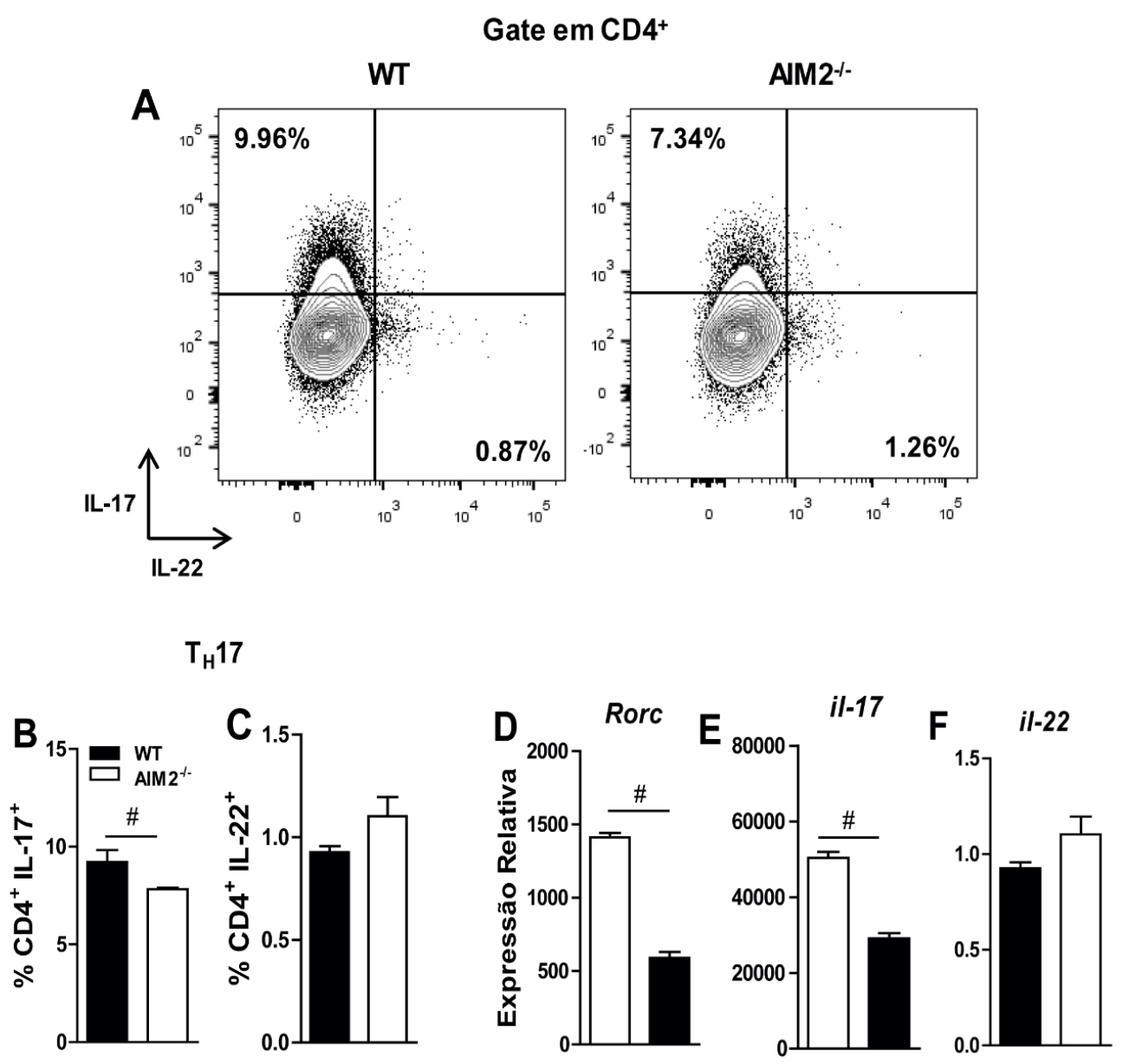

Figura 8 - 0 receptor AIM2 participa da diferenciação de linfócitos Th17 (A) Dot plot de linfócitos T CD4+IL-17+ ou IL-22+WT e AIM2-/- após diferenciação sob condições polarizantes para Th17 ( $\alpha$ CD3, $\alpha$ CD28, TGF- $\beta$ e IL-6); (B, C) Porcentagem de linfócitos T CD4 IL-17+ e IL-22+; (D, E, F) Expressão gênica de Rorc, il-17 e il-22 em linfócitos T CD4 após cultura sob condições polarizantes para Th17. 


\section{9. $O$ receptor AIM2 regula à expressão de genes relacionados à resposta de linfócitos Th17 na mucosa intestinal.}

Até o momento nossos dados demonstram que a ativação de AIM2 parece influenciar na resposta de linfócitos Th17 tanto de forma dependente da ativação do complexo inflamassoma em células mieloides, quanto de forma independente, atuando durante a diferenciação de tais células.

Conforme observado anteriormente, a ativação de AIM2 parece regular a expressão de proteínas de junção e consequente permeabilidade intestinal como forma de controlar a translocação de bactérias da microbiota intestinal para os LNP, contribuindo para a resistência ao DM1. No que concerne à expressão de proteínas de junção, previamente já foi demonstrado que linfócitos Th17 regulam a expressão de tais proteínas como ZO-1, ocludina e claudina-2, aumentando ou diminuindo a expressão das mesmas através da sinalização de suas citocinas IL-17 e IL-22 (MAXWELL et al., 2015). De acordo com estes resultados, chegamos à hipótese de que a ativação de AIM2 na mucosa intestinal seria importante para uma resposta efetora de linfócitos Th17. Estas células por sua vez, poderiam atuar na expressão de proteínas de junção, e consequentemente, controlar a permeabilidade intestinal e translocação de baterias para os LNP.

Portanto, buscamos avaliar o perfil transcricional de genes relacionados à resposta de linfócitos Th17 no íleo de camundongos WT e AIM2 $2^{--}$de 0 e 7 dias após a administração de STZ. Como observado na Figura 9A, camundongos $\mathrm{AIM}^{-/}$apresentaram uma regulação negativa na expressão gênica de fatores de transcrição como RORC, IRF4 e NFAT-1 no íleo quando comparados com camundongos WT após o tratamento com STZ. Não obstante, não foram observadas diferenças na expressão de gênica da citocina TGF- $\beta$, mas houve menor expressão de IL-6, que são importantes para a diferenciação de células Th17. Além disso, citocinas como IL-1 $\beta$, IL-23, IL-17 e IL-22 tiveram sua expressão diminuída no íleo de camundongos $\mathrm{AlM}^{-/} 7$ dias após a administração de STZ, quando comparados com a expressão dos camundongos WT.

De forma interessante, foram observadas correlações positivas entre a expressão de diversos genes de células Th17 no íleo de camundongos AIM2 ${ }^{-1-}$ representadas na Figura 9B. Esta figura representa um gráfico do tipo Circos, 
que é utilizado para representar correlações entre duas ou mais variáveis. As linhas vermelhas representam correlações positivas, enquanto que as linhas azuis representam correlações negativas. Os dados representados no gráfico demonstram que na ausência do inflamassoma $\mathrm{AIM}^{-/}$há uma correlação positiva entre a diminuição da expressão gênica dos fatores de transcrição NFAT-1 e RORC com a citocina IL-1 $1 \beta$. Também foram observadas correlações positivas entre a diminuição da expressão gênica das citocinas IL-6, IL-17 e IL22 com os fatores de transcrição RORC e STAT3.

Por fim, para confirmar que a ausência de AIM2 influencia diretamente na resposta de linfócitos $\mathrm{Th17}$, buscamos caracterizar a principal célula produtora de IL-17 nos LNM de camundongos WT e AIM2-/, controles e diabéticos, 7 dias após a administração de STZ. O sétimo dia foi escolhido para tal análise devido à observação que a expressão de AIM2 aumenta no íleo de camundongos WT diabéticos apenas neste período durante o curso da doença.

De fato, observamos que a principalmente célula produtora de IL-17 nos LNMs de camundongos WT são células $\mathrm{CD}^{+}$(Th17), quando comparadas com células $\mathrm{CD}^{+}$(Tc17), células linfoides inatas do tipo 3 (ILC-3) ou células Ty $\delta$ (Figura 9C). Porém, a deficiência de AIM2 reduziu de maneira significativa esse subtipo celular nos LMN em relação aos WT após STZ.

Estes dados confirmam nossa hipótese que a ativação de AIM2 parece influenciar positivamente na expansão/diferenciação de linfócitos Th17 intestinais durante a progressão do DM1. 

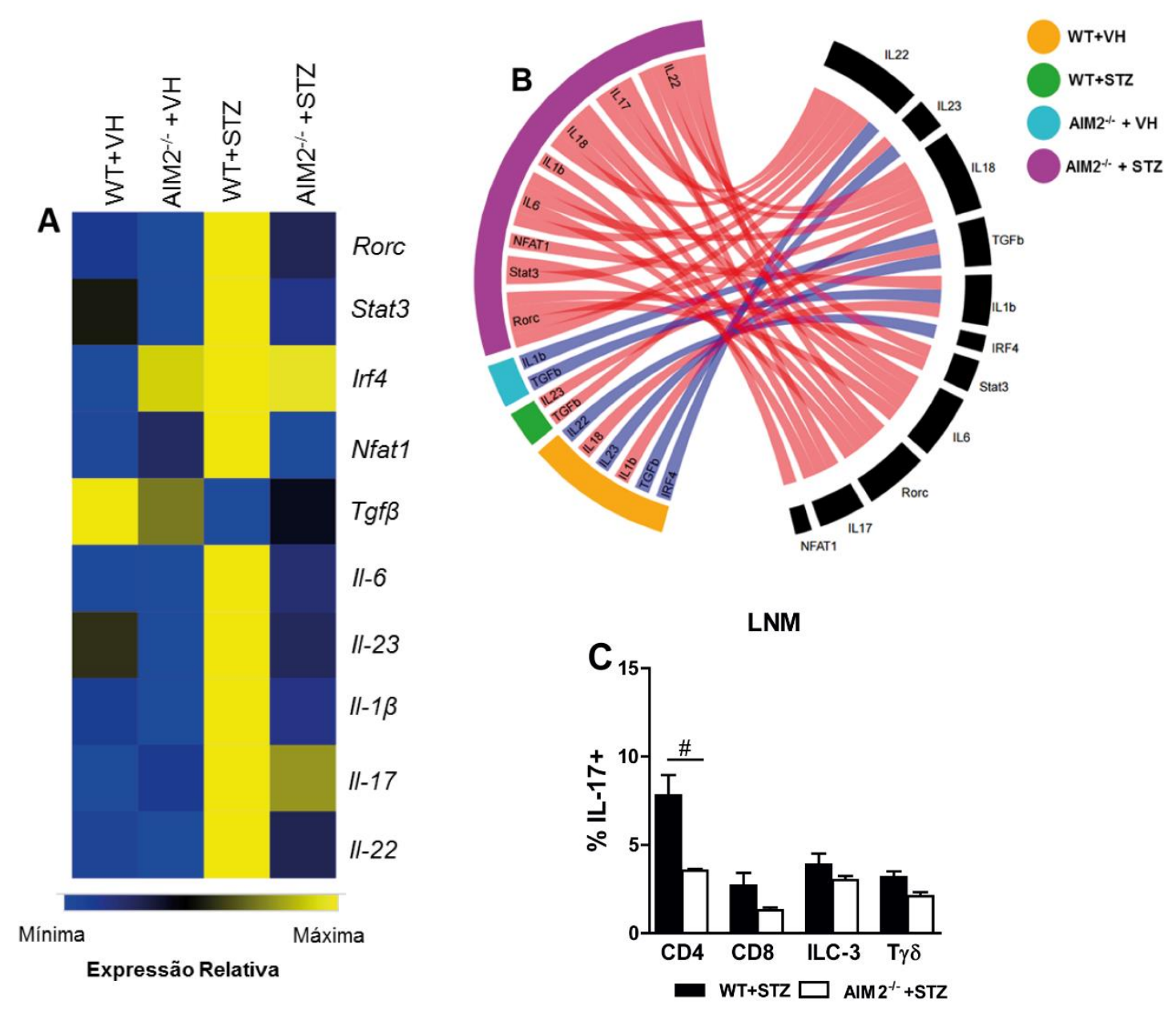

Figura 9 - A ativação do receptor AIM2 regula a expressão de genes relacionados à resposta de linfócitos Th17 no íleo; (A) Heatmap representando a expressão gênica por qPCR de genes relacionados à resposta de células Th17 no íleo de camundongos WT e AIM2 $^{-/} 7$ dias após a administração de STZ; (B) Gráfico de Circos representando a correlação entre a expressão de genes relacionados à reposta de células Th17 no íleo de camundongos WT e AIM2 $2^{-/} 7$ dias após a administração de STZ; (C) Porcentagem de células IL-17+ nos LNM de camundongos WT e AIM2 ${ }^{-/-}$diabéticos 7 dias após tratamento com STZ. 


\subsection{A deficiência de AIM2 reduziu a população de linfócitos Th17 nos LNMs e LNPs durante o DM1.}

Posteriormente, para melhor compreender como a ativação do receptor AIM2 estaria envolvida na resposta de células Th17, experimentos foram realizados para avaliar a dinâmica das células Th17 presentes na mucosa intestinal e LNPs. Sendo assim, avaliamos a população de células Th17 presentes nos LNMs e LNPs, locais onde a diferenciação de tais células ocorre. Foi observado que camundongos $\mathrm{AIM}^{-/-}$possuem uma diminuição significativa de células T CD4+IL-17+ nos LNMs e LNPs 7 e 15 dias após a administração de STZ quando comparados aos camundongos WT (Figura 10A, B, C, D, E, F).

A diminuição de linfócitos Th17 na mucosa intestinal na ausência de AIM2 reforça a importância deste receptor para na polarização destas células durante o desenvolvimento do DM1. Por um lado, a diminuição de células Th17 nos LNPs reforçou os nossos dados anteriores em que AIM2 participa diretamente da diferenciação de tais células, porém não explica o fato de camundongos $\mathrm{AIM}^{-/-}$ tornarem-se mais suscetíveis ao desenvolvimento do DM1, uma vez que linfócitos Th17 possuem um importante papel na destruição das células $\beta$ pancreáticas e consequente desenvolvimento do DM1.

Em linhas gerais, estes resultados demonstram que a ativação do receptor AIM2 parece estar envolvido na diferenciação/expansão de células Th17 intestinais e nos LNPs durante o DM1. Em resumo esse receptor parece ter um papel duplo tanto na modulação da resposta Th17, assim como no controle da permeabilidade intestinal e translocação bacteriana; levando assim à imunoregulação da doença. 
Linfonodos Mesentéricos
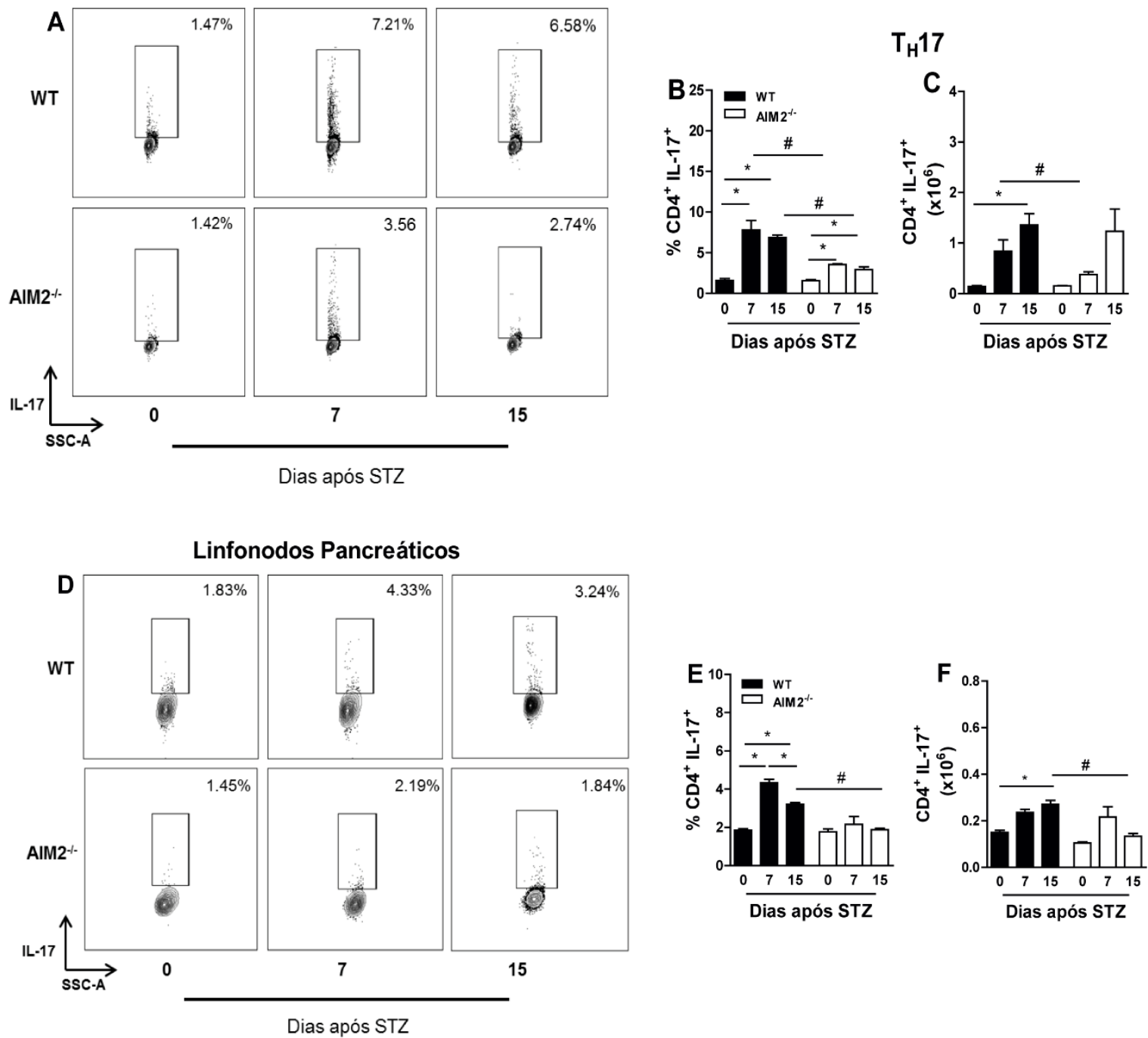

Figura 10 - A ativação do receptor AIM2 regula de forma positiva a resposta de linfócitos Th17 nos LNP e LNM; (A, D) Dot plots representativos da porcentagem de células T CD4+IL-17+ nos LNM e LNP de camundongos WT e AIM2 ${ }^{-/}$0, 7 e 15 dias após a administração de STZ; (B, C, E, F) Porcentagem e número absoluto de células T CD4+IL$17^{+}$nos LNM e LNP de camundongos WT e AIM2-- 0,7 e 15 dias após a administração de STZ. 


\subsection{A ativação de AIM2 não alterou a população de linfócitos Tc17}

nos LNPs durante o DM1.

Posteriormente, foi avaliada a resposta de células $\mathrm{T} C D 8^{+}$produtoras de IL-17 (Tc17) nos LNP. Tais células já foram descritas como patogênicas no modelo experimental de DM1 induzido por STZ (YAOCHITE et al., 2013).

Nossos resultados demonstram que camundongos $\mathrm{AIM}^{-/-}$possuem um aumento porcentagem (\%) T CD8+IL-17+ nos LNP 15 dias após a administração de STZ quando comparado com camundongos $\mathrm{AIM2}^{--}$não diabéticos, contudo tal diferença não foi observada quando comparado a porcentagem de células $T$ CD8 produtoras de IL-17 nos LNPs de camundongos WT diabéticos (Figura 11A, B, C).

Desta forma, estes resultados demonstram que a ativação do receptor AIM2 parece não influenciar de maneira significativa na modulação da resposta de células Tc17 ao DM1, o que sugere o que outro subtipo celular estaria envolvido na suscetibilidade ao DM1. 


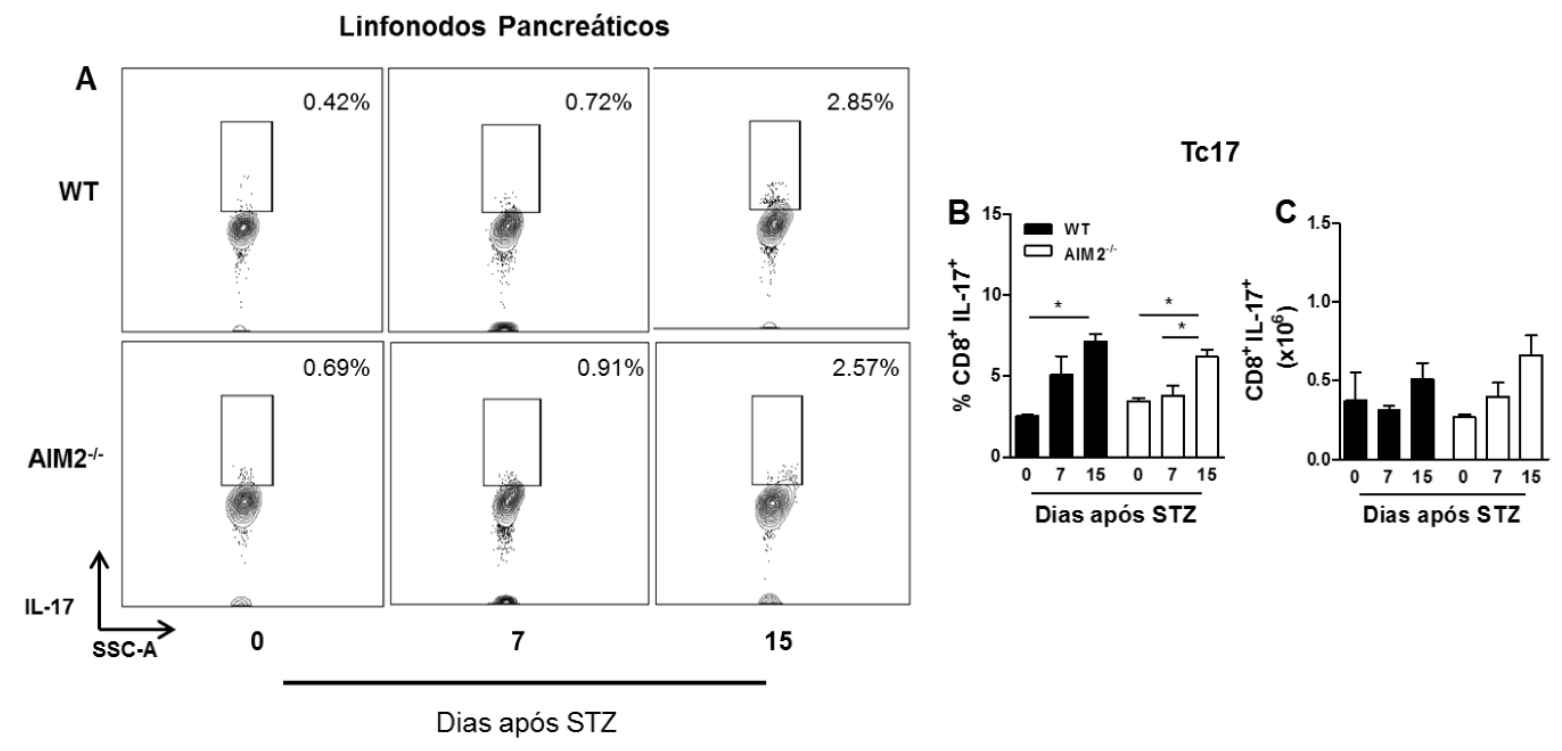

Figura 11 - A ativação do receptor AIM2 não interfere na produção de IL-17 por células T CD8 nos LNP; (A, B) Dot plots representativos da porcentagem de células T CD8+IL-17+ nos LNPs de camundongos WT e AIM2 ${ }^{-/} 7$ e 15 dias após a administração de STZ; (C) Número absoluto de células T CD4+IL-17+ nos LNPs de camundongos WT e AIM2-- 15 dias após a administração de STZ. 


\subsection{A deficiência de AIM2 prejudica a produção de citocinas}

relacionadas ao perfil de reposta Th17 durante o DM1.

Por fim, buscamos avaliar se a deficiência do receptor AIM2 estaria envolvida em alterações na produção de citocinas do perfil Th17 no íleo e pâncreas de camundongos controles ou diabéticos.

Inicialmente, foi observado que camundongos $\mathrm{AlM}^{-1-}$ diabéticos apresentam uma menor produção das citocinas IL-23, IL-17 e IL-22 no íleo (Figura 12A, C, D) quando comparados com camundongos WT controles ou diabéticos, sendo ambas como já discutido anteriormente de fundamental importância para manutenção da integridade da barreira intestinal. No que tange a produção de IL-1 $\beta$, observamos uma redução das concentrações desta citocina no íleo, contudo não significativa quando comparado com camundongos WT (Figura 12B).

Já no tecido pancreático, órgão onde ocorre os mecanismos efetores de autoimunidade e progressão do DM1, observamos uma diminuição apenas dos níveis de $\mathrm{IL}-17$ em camundongos $\mathrm{AlM}^{-1-}$ quando comparados com camundongos WT controles ou tratados com STZ, não havendo diferenças nos níveis de IL-23 e IL-22 (Figuras 12E, G, H). Com relação aos níveis de IL-1 $\beta$, camundongos AIM2 $^{-/}$apresentaram um aumento significativo desta citocina quando comparados com camundongos WT tratados com STZ (Figura 12F), o que sugere a ativação de outros receptores que participam da formação do complexo inflamassoma. Não obstante, novamente estes dados reforçam nossos dados anteriores que demonstram um papel regulador do receptor AIM2 no perfil de resposta Th17 intestinal, uma vez que na sua ausência, a produção de citocinas produzidas por essas células mostrou-se reduzida no íleo. 

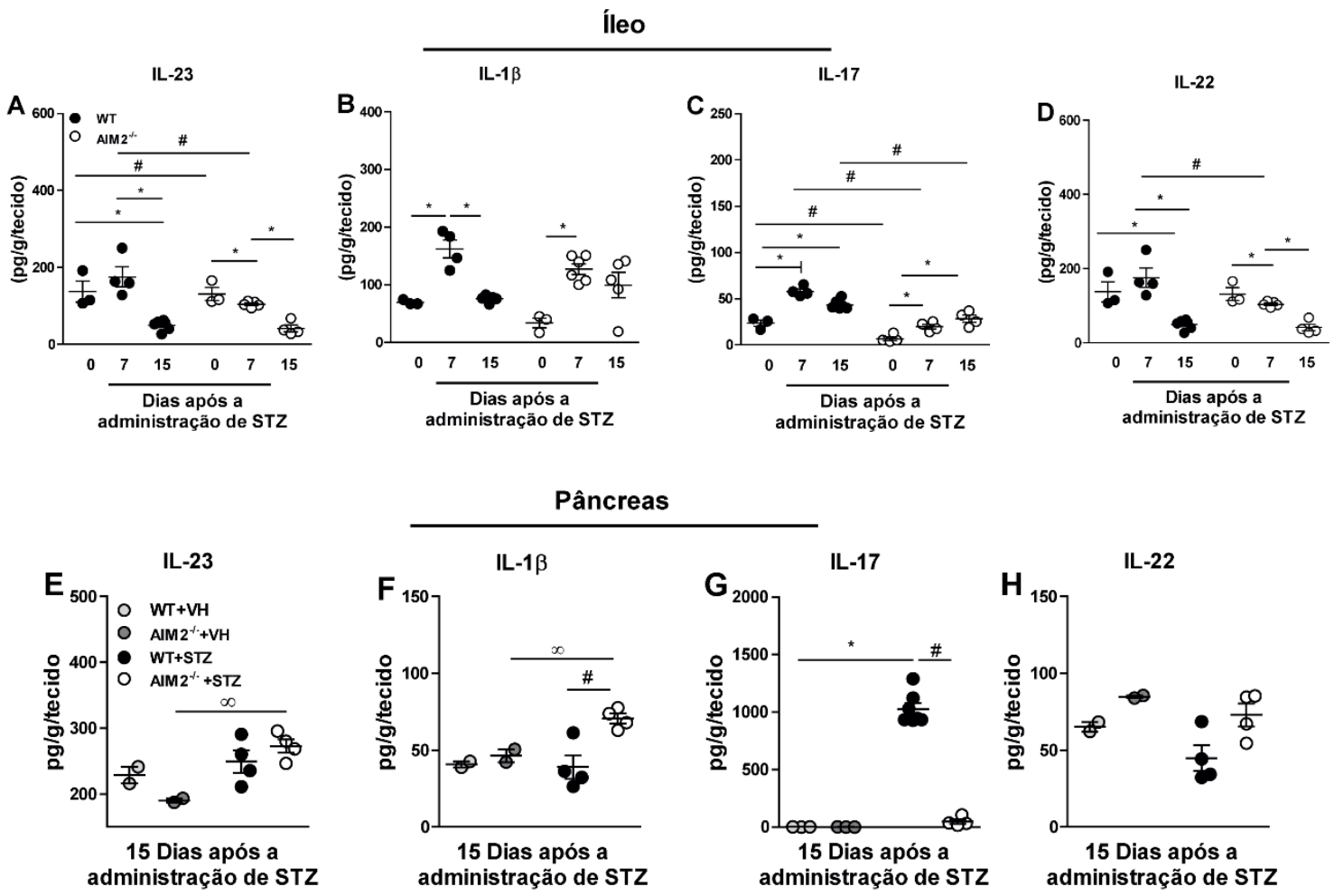

Figura 12 - A deficiência de AIM2 interfere na produção de citocinas do perfil Th17 no tecido intestinal e pancreático (A-H) Cinética de expressão proteica das citocinas IL-23, IL-1 $\beta$, IL-17 e IL-22 no íleo e pâncreas de camundongos WT e AIM2-1- controles ou diabéticos por ELISA. 


\subsection{A ativação do receptor AIM2 promoveu a migração de}

neutrófilos intestinais.

Os neutrófilos são células da imunidade inata que desempenham um importante papel na fagocitose de microrganismos como bactérias, fungos e parasitas. Em resultados anteriores, observamos que a ativação do receptor AIM2 é importante para a indução da resposta de células Th17 intestinais; estas que por sua vez atuam no recrutamento de neutrófilos através da indução da expressão de quimiocinas como CXCL-1 e CXCL-2 (WOJKOWSKA et al., 2014). Sabe-se que os neutrófilos têm um papel importante no controle da homeostase intestinal, controlando a translocação de bactérias da microbiota para a lâmina propria (DESHMUKH et al., 2014). Sendo assim, posteriormente, buscamos avaliar se a deficiência do receptor AIM2 interfere no recrutamento/ativação de neutrófilos na mucosa intestinal.

Apesar de apresentar uma nítida redução, camundongos AIM2 ${ }^{-/}$não possuem diferenças na porcentagem (\%), mas apenas no número absoluto de neutrófilos presentes nos LNM em relação aos WT após STZ (Figura 13A, B, C). De acordo, foi verificada uma diminuição nos níveis de elastase no íleo de camundongos AIM2 ${ }^{-1-} 7$ dias após a administração de STZ quando comparado com os camundongos WT (Figura 13D).

No que concerne à resposta de neutrófilos nos LNP, não foram observadas diferenças significativas na porcentagem e número absoluto destas células quando comparados camundongos WT e AIM2-/- diabéticos, sugerindo que a ativação do receptor AIM2 parece não influenciar na migração de neutrófilos nesse compartimento. (Figura 13E, F, G). Com base nestes resultados concluímos que influxo de neutrófilos mediada pela ativação do receptor AIM2 pode ser um mecanismo inato importante para o controle da translocação de bactérias da microbiota para os LNP, que consequentemente contribui para a proteção ao DM1. 

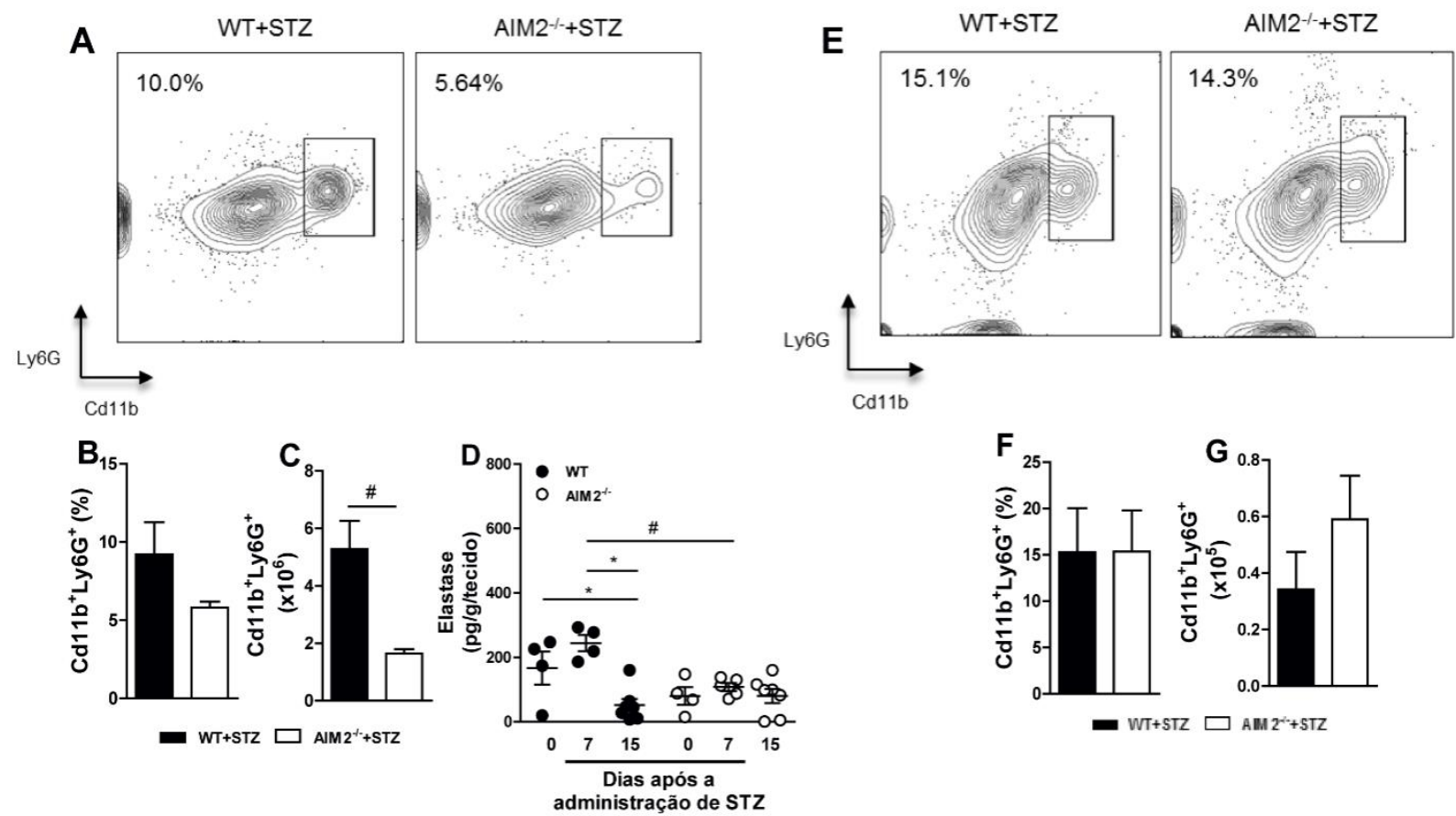

Figura 13 - A ativação de AIM2 é importante para a resposta de neutrófilos intestinais (A, B, C) Representação da porcentagem e número absoluto de células $C$ d11 b ${ }^{+} L_{\text {Ly }} \mathrm{G}^{+}$nos LNM de camundongos WT e AIM2 $2^{-/-}$diabéticos após 15 dias da administração de STZ; (C) Cinética da produção de elastase no íleo de camundongos WT e AIM2 ${ }^{-/-}$0, 7 e 15 dias após a administração de STZ; (E, F, G) Representação da porcentagem e número absoluto de células Cd11 b+Ly6G+ nos LNM de camundongos WT e AIM2-- diabéticos após 15 dias da administração de STZ. 


\subsection{A deficiência de AIM2 potencializou a população de linfócitos}

Th1 nos LNP durante o DM1.

Os linfócitos T CD4 produtores de IFN-y representam uma importante subpopulação de linfócitos $T$ auxiliares que participam da promoção de processos autoimunes (MARTIN-OROZCO et al., 2009); (SZEBENI et al., 2005). Ao avaliar dinâmica de resposta de linfócitos Th1 nos LNM observamos diferenças apenas na porcentagem destas células, que se apresentaram diminuídas em camundongos AIM2 ${ }^{--}$quando comparado aos camundongos WT diabéticos (Figura 14A, B, C).

Já nos LNP, camundongos AIM2 ${ }^{-/-}$diabéticos apresentaram um aumento da porcentagem destas células quando comparados aos controles e WT diabético, contudo não foram observadas diferenças no número absoluto destas células entre os grupos (Figuras 14D, E, F). Desta forma, a ativação do inflamassoma parece regular de forma negativa a expansão/diferenciação de linfócitos Th1 nos LNP durante o DM1. 

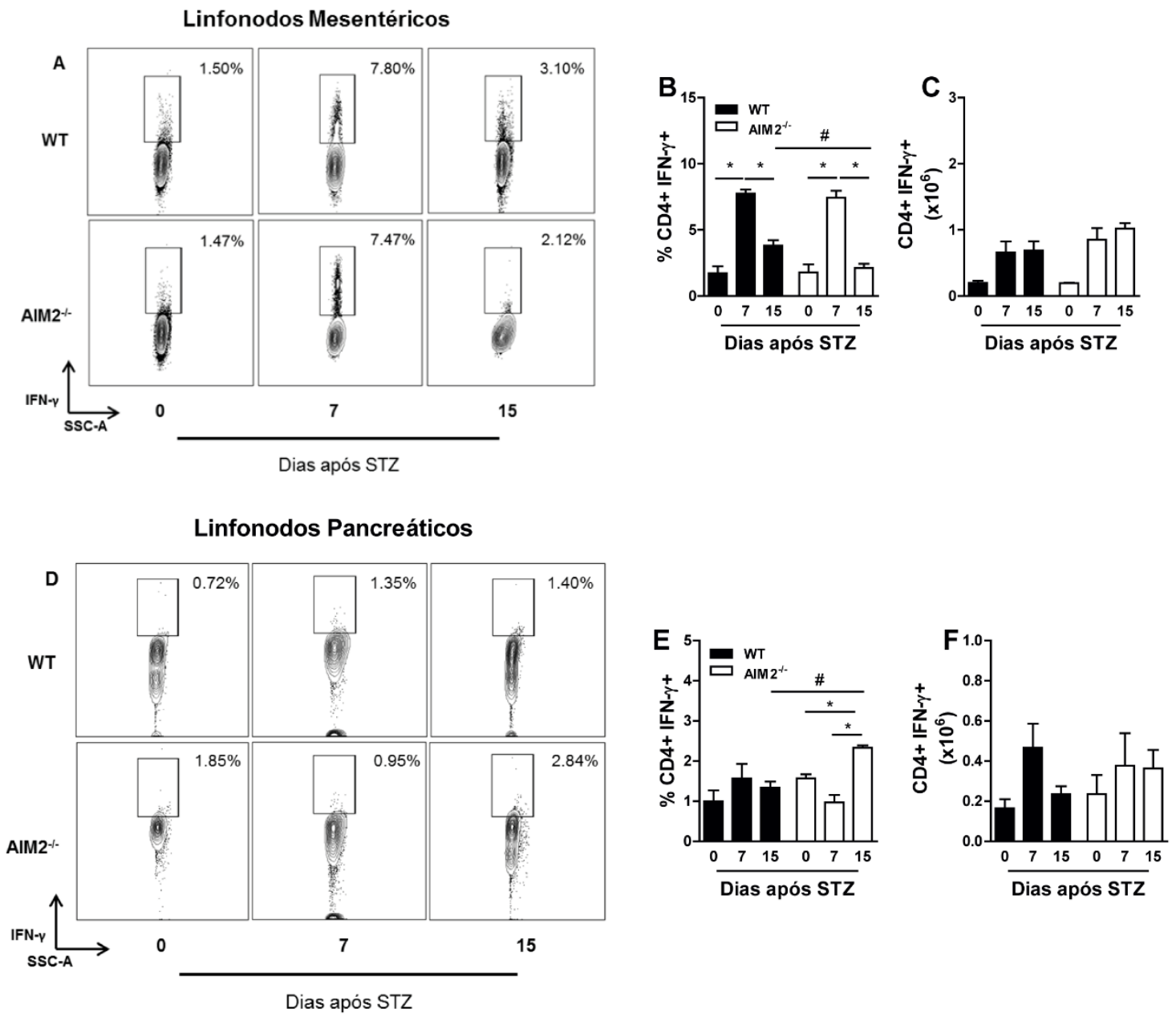

Figura 14 - A ativação de AIM2 modula negativamente a reposta de linfócitos Th1 (A, D) Dot plots representativos da porcentagem de células T CD4 ${ }^{+} I F N-\gamma^{+}$nos LNM e LNP de camundongos WT e AIM2 ${ }^{-/}$0, 7 e 15 dias após a administração de STZ; (B, C, E, F). Porcentagem e número absoluto de células T CD4+IFN $-\gamma^{+}$nos LNM e LNP de camundongos WT e AIM2 ${ }^{-/-}$0, 7 e 15 dias após a administração de STZ. 


\subsection{A deficiência de AIM2 potencializou a população de linfócitos}

Tc1 nos LNP durante o DM1

Um outro subtipo de linfócitos que tem um papel fundamental na destruição das células $\beta$ pancreáticas são os linfócitos T CD8 produtores de IFNY (Tc1), que como já mencionado anteriormente, podem mediar a destruição das células $\beta$ tanto pelo contato celular e consequente liberação de granzima e perforina, que são mediadores citotóxicos para a células, levando a apoptose das mesmas, quanto pela produção da citocina IFN-Y (SAXENA et al., 2012; YI et al., 2012).

Ao avaliar a presença de linfócitos Tc1 nos LNM, não observamos diferenças na porcentagem e número absoluto destas células em camundongos AIM2 $^{-/-}$quando comparado aos camundongos WT diabéticos (Figura 15A, B, C). De maneira interessante, observamos um aumento significativo de linfócitos Tc1 nos LNP de camundongos AIM2 ${ }^{-/}$diabéticos quando comparado com os WT diabéticos e respectivos controles, sugerindo uma possível participação destas células na suscetibilidade ao DM1 em camundongos AIM2 $2^{-}$. 

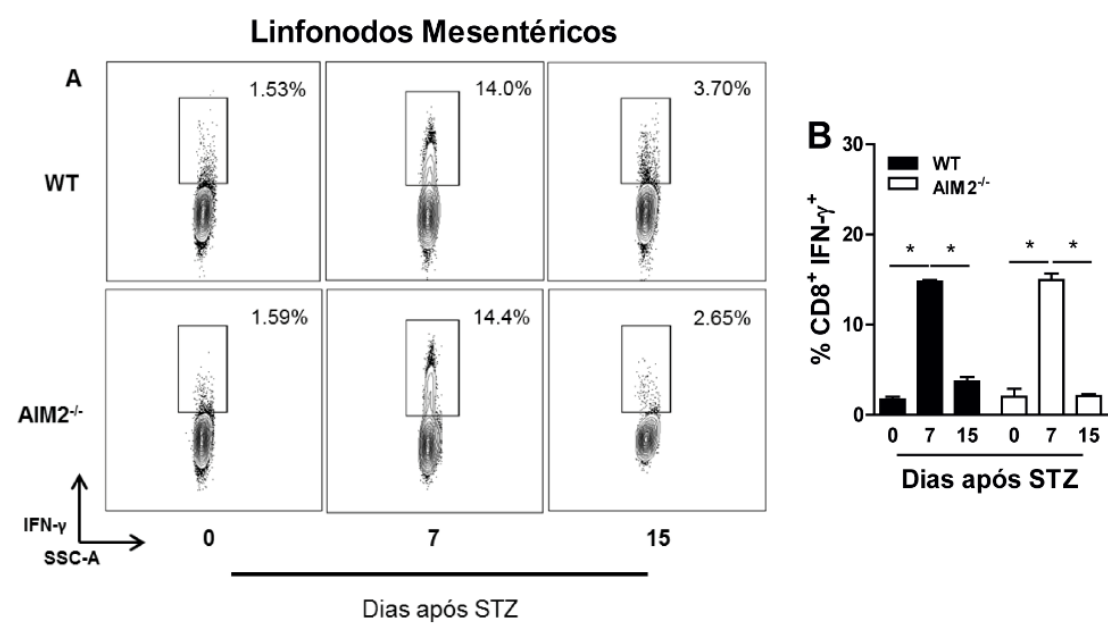

$\mathrm{T}_{\mathrm{c}} 1$

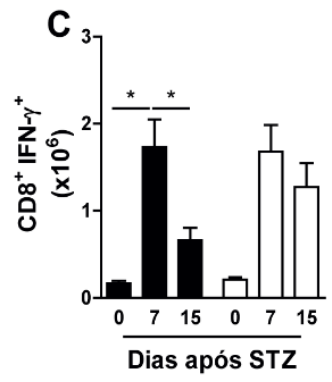

Linfonodos Pancreáticos
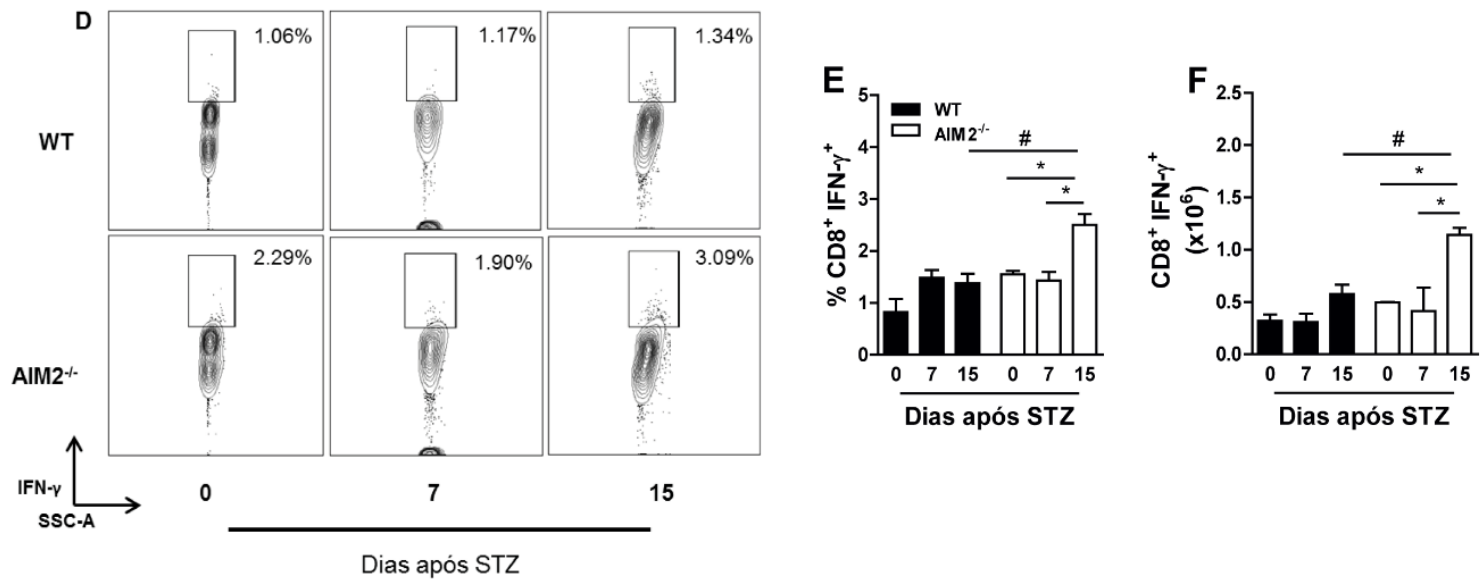

Figura 15 - A ativação de AIM2 modula negativamente a reposta de linfócitos Tc1 (A, D) Dot plots representativos da porcentagem de células T CD8 ${ }^{+} I F N-\gamma^{+}$nos LNM e LNP de camundongos WT e AIM2 ${ }^{--}$0, 7 e 15 dias após a administração de STZ; (B, C, E, F) Porcentagem e número absoluto de células T CD8 ${ }^{+}$IFN- $\gamma^{+}$nos LNM e LNP de camundongos WT e AIM2 $2^{--}$0, 7 e 15 dias após a administração de STZ. 


\subsection{A deficiência de AIM2 aumenta à produção de citocinas do perfil Th1/Tc1 no pâncreas durante o DM1}

Por fim, para confirmar o envolvimento da resposta de células Th1/Tc1 na suscetibilidade ao DM1 em camundongos $\mathrm{AlM}^{-/-}$avaliamos os níveis das citocinas IL-12p70 e IFN- $\gamma$, no íleo e pâncreas dos respectivos animais.

Nossos resultados demonstraram um significativo aumento dos níveis de IL-12p70 e IFN-y no pâncreas de camundongos AIM2\% submetidos ao tratamento com STZ quando comparado aos WT diabéticos e controles (Figura 16A, B). Tais dados demonstram que a alta suscetibilidade ao DM1 observada em camundongos $\mathrm{AlM}^{-/-}$ocorre devido ao aumento da resposta mediada principalmente por células Tc1, que possivelmente através da produção de IFN$\gamma$, promove a destruição das células $\beta$ pancreáticas. Com relação, aos níveis de IL-10, não observamos diferenças significativas nos níveis desta citocina no pâncreas de animais WT e AIM2/-- controles ou diabéticos (Figura 16C).

Não observamos diferenças significativas na produção de IL-12p70 e IFNy no íleo de camundongos WT e AIM2 $2^{-/-}$diabéticos 7 dias após a administração de STZ (Figuras 16 D, E) quando comparados com os controles. No entanto, 15 dias após a administração de STZ é observada uma redução nos níveis de IL-12p70 no íleo desses animais, fato este que foi correlacionado ao aumento de IL-10 observado no íleo de camundongos AIM2-/- diabéticos (Figura 16F). 


\section{Pâncreas}
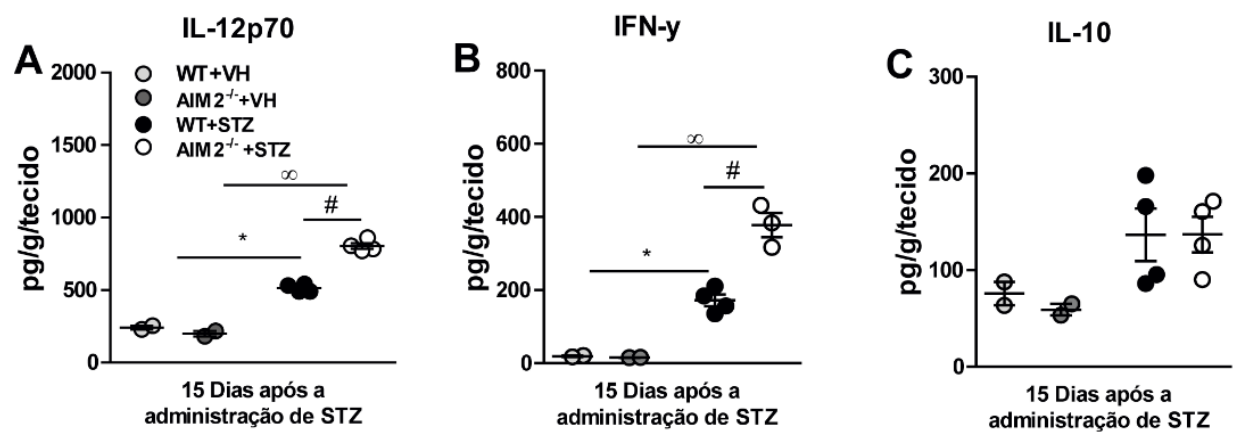

íleo
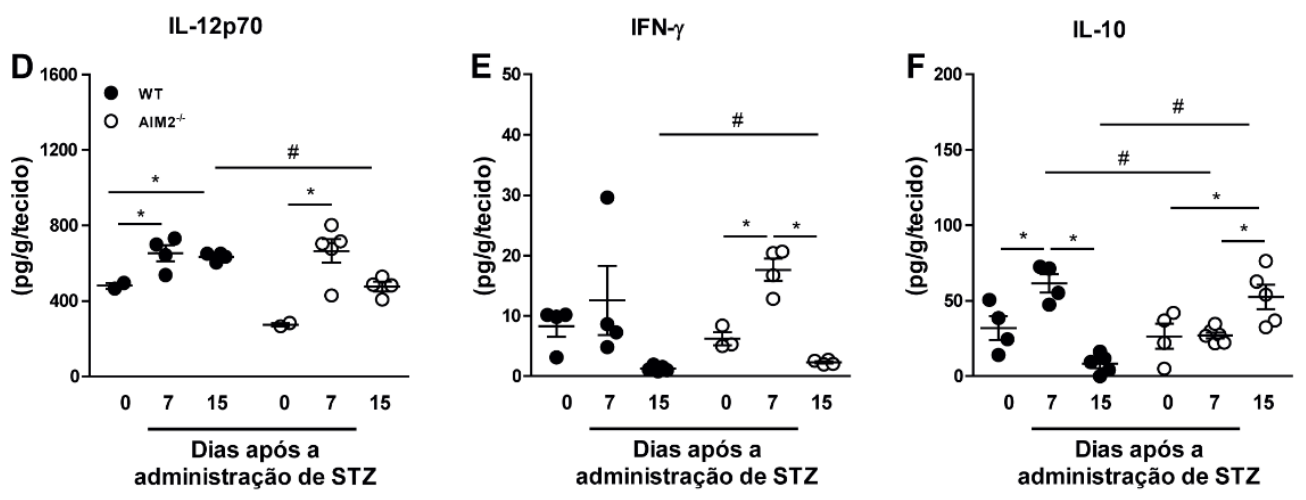

Figura 16 - A deficiência de AIM2 interfere na produção de citocinas do perfil Th1/Tc1 no tecido intestinal e pancreático $(\mathbf{A}-\mathrm{H})$ Cinética de expressão proteica das citocinas IL12p70, IFN- $\gamma$, IL-10 no íleo e pâncreas de camundongos WT e AIM2 $2^{-/-}$controles ou diabéticos por ELISA. 


\subsection{A deficiência de AIM2 aumenta à expressão de genes relacionados a resposta imune inata nos LNP}

Por fim, buscamos avaliar o mecanismo pelo qual na ausência de AIM2-/houve um aumento de células Tc1 nos LNP durante o DM1, estas que por sua vez mostraram-se como as principais células responsáveis pela suscetibilidade ao DM1 na ausência do receptor AIM2.

Estudos recentes demonstraram que a ativação de receptores da imunidade como os TLRs e consequente produção de IFN do tipo 1 tem um papel crucial na resposta de linfócitos T CD8 diabetogênicos (ZHANG et al., 2010). Baseado nestes estudos nosso último objetivo foi entender se a deficiência de AIM2 poderia estar interferir na expressão gênica de receptores e moléculas relacionados à vias de ativação dos receptores do tipo toll, assim como de receptores NLRs e consequentemente contribuir para a suscetibilidade ao DM1.

De maneira interessante, foi observado que quando comparados aos WT camundongos $\mathrm{AlM}^{-/}$diabéticos possuem um significativo aumento da expressão de genes relacionados às vias dos receptores do tipo toll (TIr4, TIr9, Myd88, IFN- $\beta$ ) nos LNP 15 dias após o tratamento com STZ, assim como do receptor NIrp1b e da citocina IL-1 $\beta$ (Figura 17A).

Não foi verificado diferenças no porcentagem e número absoluto de células dendríticas CD11C+ nos LNPs entre os grupos estudados (Figuras 17BC). Todavia, foi observado um significativo aumento da porcentagem e número absoluto de células dendríticas positivas para TLR4 e TLR9 presentes nos LNP de camundongos $\mathrm{AlM}^{-/-}$diabéticos quando comparados aos WT (Figuras 17EJ).

Com base nas evidências já apresentadas na literatura, nossos dados sugerem que o aumento de células Tc1 nos LNP de camundongos AIM2-/diabéticos pode estar relacionado com a ativação de receptores do tipo toll, que através da produção de IFN-I atuam aumentando a proliferação de células Tc1, resultando na destruição das células $\beta$ pancreáticas, o que explica a suscetibilidade ao DM1 em camundongos AIM2--. 

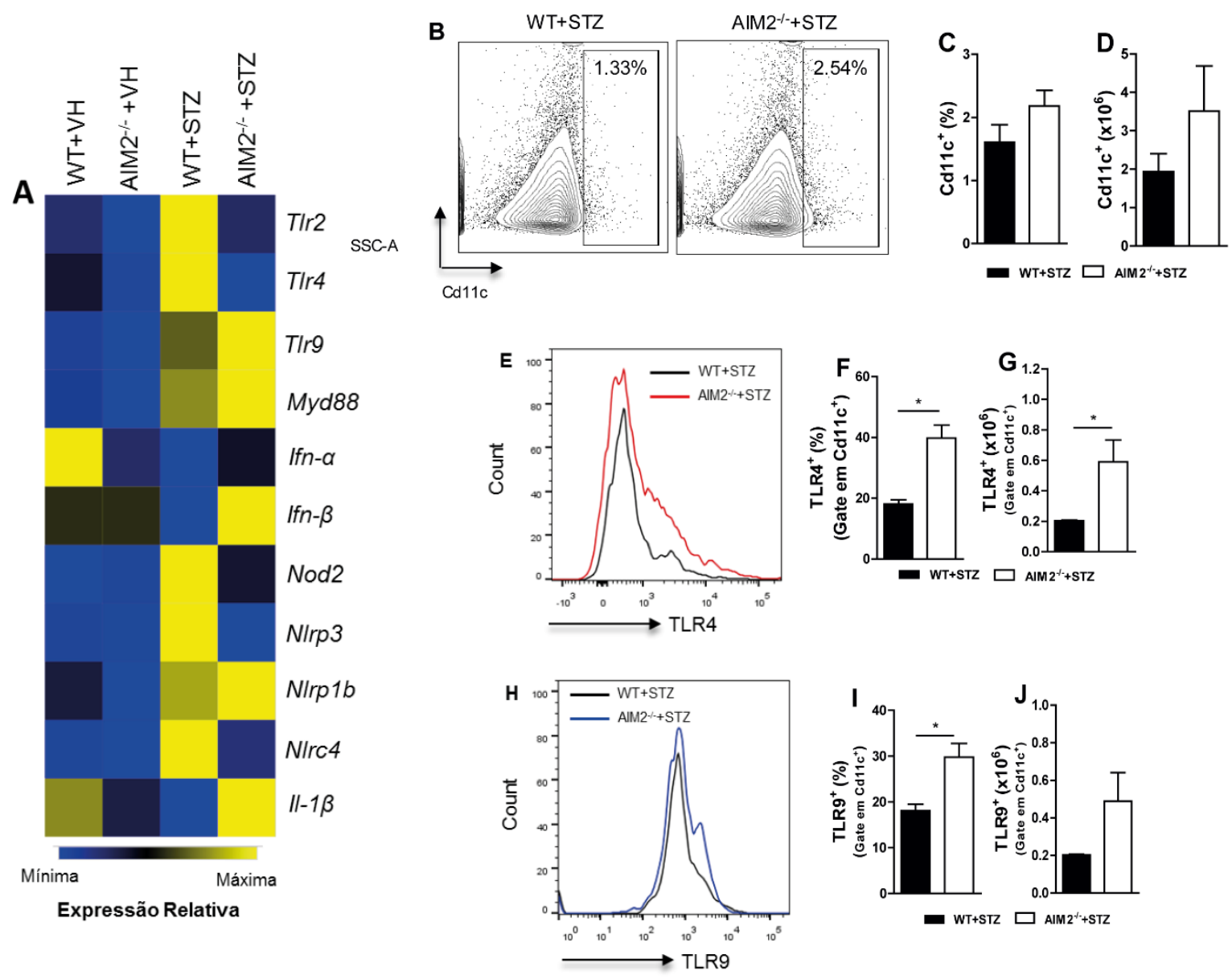

Figura 17 - A deficiência de AIM2 regula a expressão dos receptores TLR4 e TLR9 em células dendríticas nos LNP durante o DM1 (A) Heatmap da expressão de genes relacionadas às vias de ativação dos receptores TLRs e NLRs nos LNP de camundongos WT e AIM2 ${ }^{-/}$controles ou diabéticos após 15 dias da administração de STZ; (B, C) Representação da porcentagem e número absoluto de células $\mathrm{Cd}_{11 c^{+}}$nos LNPs de camundongos WT e AIM2 ${ }^{-/}$controles ou diabéticos após 15 dias da administração de STZ;

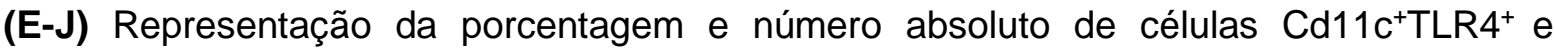
Cd11 $\mathrm{C}^{+} \mathrm{TLR}^{+}$nos LNPs de camundongos WT e AIM2 ${ }^{-/}$controles ou diabéticos após 15 dias da administração de STZ. 
5 Díscussão 
Nosso sistema imune está constantemente exposto a uma infinidade de estímulos antigênicos de origem externa ou interna, sejam de caráter infeccioso (bactérias, fungos, vírus), comensais (microbiota) ou auto-antígenos provenientes de células mortas do próprio indivíduo. Neste contexto, as células do nosso sistema imune devem ser capazes de discernir o que é prejudicial ou não para o hospedeiro, através de um mecanismo chamado tolerância imunológica. Contudo, quando estes mecanismos de auto-tolerância falham, ocorre o desencadeamento de respostas autoimunes, caracterizadas pela destruição de células, tecidos e órgãos do hospedeiro, gerando efeitos deletérios (KUGELBERG, 2016).

Um exemplo de doença autoimune que vem sendo amplamente estudada há décadas é o diabetes melitos tipo 1, que tem como principal característica a destruição de células $\beta$ pancreáticas produtoras de um hormônio chamado insulina, que é essencial para a regulação do metabolismo da glicose. A destruição de tais células é mediada por inúmeras células e componentes do sistema imune, tanto inato, quanto adaptativo (CASTANO; EISENBARTH, 1990). Porém, apesar de inúmeros estudos, ainda restam grandes lacunas para o entendimento da fisiopatologia desta doença. Portanto, é de suma importância entender os mecanismos envolvidos no desenvolvimento do DM1, para que novas abordagens terapêuticas sejam estabelecidas e proporcionem a melhora ou cura do quadro clinico dos pacientes acometidos por esta doença.

Neste estudo, demonstramos que o receptor da imunidade inata AIM2 tem um papel fundamental na proteção ao desenvolvimento do DM1, de forma que ao ser ativado na mucosa intestinal regula de maneira positiva a expressão de proteínas de junção celular expressas nas células epiteliais do intestino, prevenindo a translocação de bactérias da microbiota em disbiose, que é um dos fatores de predisposição no desenvolvimento do DM1 (COSTA et al., 2016). Por outro lado, a ativação de AIM2 nos LNP parece inibir a produção de citocinas pró-inflamatórias como IFN- $p$ por linfócitos T CD8 (Tc1), como forma de proteger contra a resposta de tais células. Não obstante, de maneira inédita, nosso estudo demonstrou que o receptor AIM2 parece desempenhar funções durante à diferenciação de linfócitos Th17, que possui um papel importante na manutenção da integridade da barreira intestinal da mucosa intestinal, enquanto que nos 
linfonodos drenantes do pâncreas e tecido pancreático, desempenha um papel patogênico.

A ativação de receptores da imunidade inata, como os da família dos NLRs parece ter um papel fundamental no controle ou desenvolvimento do DM1. Nosso grupo de pesquisa tem focado, nos últimos anos, em entender os mecanismos pelos quais tais receptores estão envolvidos na patogênese do DM1. Demonstramos que o receptor NOD2, por exemplo, está envolvido na suscetibilidade ao DM1, através de um mecanismo envolvendo o reconhecimento de bactérias da microbiota em disbiose que translocam para os LNP. São, então, reconhecidas por este receptor expresso em células dendríticas e macrófagos, que posteriormente através da ativação de linfócitos T é gerado um microambiente inflamatório que culmina na destruição das células B pancreáticas (COSTA et al., 2016). Já a ativação de outro receptor da família dos NLRs, NLRP3, por DNA mitocondrial, leva ao desenvolvimento do DM1 através da produção de IL-1 $1 \beta$ e IL-18 proveniente da ativação do complexo inflamassoma. Tais citocinas atuam potencializando, respectivamente, a resposta de células Th17 e Th1 (CARLOS et al., 2017). De maneira oposta, outro sensor da imunidade inata, o receptor NLRP1, apresentou um papel protetor durante o desenvolvimento do DM1, uma vez que camundongos deficientes para este receptor se tornam suscetíveis ao desenvolvimento da doença, apresentando elevados níveis de glicemia. Quando investigado o mecanismo envolvido na resistência ao DM1, observamos que NLRP1 atua como um regulador negativo na resposta de linfócitos Th17, inibindo a produção de IL-17, e consequentemente protegendo contra a destruição das células $\beta$ pancreáticas, o que proporcionou a resistência ao desenvolvimento do DM1 (COSTA et al., 2018).

Os receptores que participam da formação do complexo inflamassoma incluem tanto os NLRs (NLRP3, NLRP1, NLRC4, NLRP6, NLRP9, NLRP12) e ALRs (AIM2), reconhecem ligantes específicos e posteriormente através da clivagem proteolítica das formas imaturas das citocinas IL-1 $1 \beta$ e IL-18 pela enzima caspase-1, que são liberadas para o meio extracelular e desempenham papel pró-inflamatório (GUO et al., 2015). Estudos desenvolvidos nos últimos anos apontam que um desses receptores, o receptor AIM2, possui um papel fundamental na patogênese de doenças autoimunes, como o lúpus eritromatoso 
sistêmico e a psoríase (DOMBROWSKI et al., 2011; KIMKONG et al., 2009). Estas evidências nos levaram à hipótese de que a ativação de AIM2 poderia contribuir para a patogênese do DM1.

Nossos dados iniciais demonstraram um aumento da expressão gênica e proteica do receptor AIM2 e de moléculas relacionadas à sua via de sinalização, tais como IL-1 $\beta$ e IL-18, nos LNP e íleo de camundongos WT, 7 e 15 dias após o tratamento com STZ, o que sugere o envolvimento deste receptor durante o desenvolvimento do DM1. Posteriormente, buscamos entender se a deficiência do receptor AIM2 poderia influenciar na suscetibilidade ou resistência ao DM1. De forma surpreendente, $100 \%$ dos camundongos AIM $^{-/-}$tornam-se suscetíveis ao desenvolvimento do DM1 no $7^{\circ}$ dia após a administração de STZ, apresentando altos níveis de glicose 7 e 15 dias após a indução da doença, caracterizando assim um estado de hiperglicemia. Além disso, esses animais apresentaram significativo aumento do infiltrado inflamatório nas ilhotas pancreáticas, assim como uma reduzida produção de insulina por células $\beta$ pancreáticas, indicando que a deficiência do AIM2 agravou o desenvolvimento do DM1. Tais dados foram contra a nossa hipótese inicial, na qual a ativação de AIM2 poderia exercer um papel patogênico durante o DM1 através do reconhecimento de DNA próprio proveniente de autoantígenos do pâncreas. Com isso, nosso próximo passo foi tentar entender a maneira que a ativação de AIM2 estaria controlando o desenvolvimento do DM1.

Estudos recentes já haviam demonstrado que a ativação do receptor AIM2 desempenha um papel importante no controle da homeostase intestinal. Hu et al. (2015) demonstraram que a ativação do inflamassoma AIM2 protege contra o desenvolvimento de colite através da indução de peptídeos antimicrobianos como Reg3 $\beta$, Reg3y, S100A8, S100A9 e Lcn2, mediada por citocinas como IL-1 $\beta$ e IL-18. A expressão de tais peptídeos controla 0 crescimento de bactérias como $E$. coli que está associada ao desenvolvimento da doença durante um processo de disbiose intestinal. Não obstante, Ratsimandresy et al., (2017) demonstraram que a ativação do inflamassoma AIM2 e consequente produção de IL-18, conduz uma resposta efetora de IL-22 no colón que regula a produção de peptídeos antimicrobianos e atua na prevenção de uma disbiose intestinal. 
Baseados nestes dados que apontam o receptor AIM2 como um regulador da homeostase intestinal, e através do aumento da expressão deste receptor observado na mucosa intestinal nos estágios iniciais do desenvolvimento do DM1, nosso próximo passo foi compreender se a função de AIM2 durante o DM1 estaria relacionada com o controle da disbiose intestinal e da translocação de bactérias da microbiota intestinal para os LNP e consequente retardo no desenvolvimento da doença. Como mencionado acima, Costa et al., (2016) demonstraram que a translocação de bactérias da microbiota intestinal para os LNP causada por uma disbiose intestinal, contribui para o início do DM1. Após a translocação de tais bactérias, ocorre à ativação do receptor NOD2 em células mieloides, este por sua vez regula a produção de citocinas próinflamatórias como IL-12 e IL-6, que induzem a diferenciação de células Th1 e Th17. Essas células patogênicas contribuem para a destruição das células $\beta$ pancreáticas produtoras de insulina, levando ao início do desenvolvimento do DM1.

De fato, foi observado um aumento significativo de bactérias nos LNP de camundongos $\mathrm{AIM}^{-{ }^{-}}$no $7^{\circ}$ e $1^{\circ}$ dia após a indução da doença quando comparados com camundongos WT. Em seguida, foi realizada uma caracterização em nível de filo do perfil de bactérias presentes nos LNP em camundongos $\mathrm{AlM}^{-/-}$. Observamos alta expressão gênica de bactérias do filo Bacteroidetes e Firmicutes nos LNP e nas fezes de camundongos AIM2-/- 15 dias após a indução da doença quando comparado com camundongos WT diabéticos. Enquanto que a expressão de bactérias do filo Actinobactéria, Proteobactéria e Verrucomicrobia, apresentou-se diminuída nos LNP e fezes de camundongos $\mathrm{AlM}^{-/-}$. É importante ressaltar que pacientes jovens com DM1 possuem uma alta expressão de bactérias do filo Bacteroidetes nas fezes, assim como de bactérias do gênero Bacteroides (DE GOFFAU et al., 2014). A confirmação que a translocação de bactérias da microbiota estaria envolvida na suscetibilidade ao DM1 em camundongos $\mathrm{AIM}^{-/-}$foi demonstrada através de um ensaio de depleção da microbiota, de forma que camundongos WT e AIM2 $2^{-/}$que tiveram sua microbiota depletada não desenvolveram DM1 após receberem o tratamento com STZ.

Os dados que demonstraram uma elevada translocação de bactérias da microbiota em disbiose para os LNP na ausência AIM2 durante o DM1, sugerem 
um papel deste receptor na manutenção da integridade intestinal. Com base nisso, buscamos compreender se ativação do AIM2 poderia interferir de forma positiva na expressão de proteínas de junção celular expressas no epitélio intestinal. Sabe-se que um aumento da permeabilidade intestinal causada por alterações na expressão de proteínas de junção celular (Tight junction proteins) está associado com a translocação de bactérias do lúmen intestinal para a lâmina propria (LP) (ARRIETA et al., 2006). De fato, foi observada uma expressão diminuída das proteínas de junção ZO-1 e ocludina no íleo de camundongos $\mathrm{AIM}^{-/-} 7$ e 15 dias após o tratamento com STZ. Em contrapartida, camundongos $\mathrm{AIM2}^{-/-}$possuem um aumento significativo da expressão gênica e proteica de claudina-2 no íleo no $7^{\circ}$ dia após a indução da doença quando comparados com os animais WT. Nossos dados corroboram com dados da literatura, que demonstram que a expressão aumentada de claudina-2 está associada com maior permeabilidade intestinal, devido esta proteína formar poros na membrana das células do epitélio (ZEISSIG et al., 2007). Por outro lado, o aumento da expressão das proteínas de junção ZO-1 e ocludina estão associados com maior integridade celular e diminuição da permeabilidade intestinal, protegendo contra doenças como colite (KYOKO et al., 2014; PORITZ et al., 2007). De forma interessante, pacientes com diabetes tipo 1 possuem um aumento na permeabilidade intestinal, observada após a ingestão de açúcares, que posteriormente foram detectados no soro, o que indica uma barreira intestinal danificada(CARRATU et al., 1999).

Neste sentido, também observamos que a deficiência de AIM2 prejudica a expressão gênica de IL-18 e IL-22 no íleo durante o DM1, que como já mencionado anteriormente, possuem um papel fundamental na manutenção da produção de defensinas, peptídeos antimicrobianos e muco no intestino, atuando no controle do crescimento/translocação de bactérias patobiontes da microbiota em situações de disbiose. No estudo de Ratsimandresy et al., (2017) a deficiência do inflamassoma AIM2 contribuiu para a regulação da homeostase da microbiota intestinal e prevenção da disbiose através do reconhecimento de DNA microbiano nas células epiteliais do intestino e consequente produção de IL-18, que regula e aumenta a atividade de IL-22 no colón, possibilitando o equilíbrio da expressão de peptídeos antimicrobianos como reg3 $\beta$ e reg3y. Por outro lado, a deficiência de AIM2 prejudica a produção de IL-18 e consequente 
atuação da IL-22 o que leva à disbiose e elevada suscetibilidade à colite devido a falha na expressão de peptídeos antimicrobianos. Tais dados corroboram com os nossos achados, uma vez que camundongos $\mathrm{AlM}^{-1-}$ diabéticos apresentaram uma significativa diminuição na expressão do peptídeo antimicrobianoreg3y, mas não da defensina Defcr1, 15 dias após a indução de STZ, assim como uma menor expressão de mucina-2 e marcação de muco no íleo.

A associação da maior suscetibilidade de camundongos AlM2 $^{-/-}$ diabéticos e a presença de elevada translocação de bactérias da microbiota intestinal para os LNP, nos levou a avaliar se o DNA de uma microbiota normal ou em disbiose leva a ativação do inflamassoma AIM2 in vitro em macrófagos imortalizados ou derivados da medula óssea. Sabe-se que o tratamento com STZ é capaz de induzir disbiose intestinal em camundongos pré- diabéticos e diabéticos (PATTERSON, E. et al., 2015). Não obstante, microrganismo comensais ou em disbiose possuem mecanismos distintos na ativação de receptores da imunidade inata em células epiteliais ou da lâmina própria, que torna possível a inibição de uma resposta inflamatória contra os mesmos mediada por tais receptores (ABREU et al., 2001). Nesse contexto, observamos que comparado a macrófagos estimulados com Poly dA dT (agonista de AIM2), apenas o DNA isolado das fezes de camundongos diabéticos (DNA fecal diabético) foi capaz de ativar o inflamassoma AIM2 em macrófagos AIM2 citrina, assim como induzir a produção de altos níveis de IL-1 $\beta$ em macrófagos derivados da medula óssea. Em contrapartida, Ratsimandresy et al., (2017) verificaram que o inflamassoma AIM2 pode ser ativado por um DNA fecal isolado de um camundongo saudável. De fato, observamos uma relativa produção de IL-1ß após o estímulo com o DNA controle (não diabético), porém essa produção é muito maior após o estímulo com o DNA fecal de animais diabéticos. Fica evidente que a ativação do inflamassoma AIM2 e consequente produção de IL$1 \beta$ é maior apenas com o estímulo do DNA de uma microbiota alterada. Isso pode ser explicado, por exemplo, uma vez que o estímulo com DNA isolado de uma microbiota em disbiose conter sequências de CpG não metiladas, que atuam com ligantes de TLR9, que ao ser estimulado pelo DNA de bactérias em disbiose, estimula a produção de IFN do tipo 1, que por sua vez é um potente regulador da expressão de AIM2 em macrófagos (BERESWILL et al., 2014; FANG et al., 2014). Adicionalmente, pode ocorrer um mecanismo de regulação 
positiva da expressão de receptores inatos em condições de doença, como é o caso da ativação dos receptores TLR2 e TLR4, que possuem uma baixa expressão em células epiteliais do intestino, mas em condições de inflamação, apresentam sua expressão aumentada.

Com base na observação de que o DNA de bactérias da microbiota induz a ativação de AIM2 e consequente produção de IL-1 1 , chegamos a hipótese que a ativação de AIM2 poderia atuar de forma indireta, através da citocina IL-1 $\beta$ sobre linfócitos Th17 intestinais, uma vez que tal citocina é um mediador chave para a expansão destas células no local de inflamação. Não obstante, estudos recentes têm demonstrado que citocinas do perfil Th17 como IL-17 e IL-22 possuem um papel crucial na manutenção da permeabilidade intestinal através da regulação da expressão de proteínas de junção celular (MAXWELL et al., 2015). De fato, observamos que a população de linfócitos Th17 está diminuída no íleo de camundongos saudáveis, enquanto os camundongos WT diabéticos apresentaram um aumento significativo da população de linfócitos Th17 nos LNM, 7 dias após a indução de STZ (momento em que é observado a maior expressão de AIM2), em relação aos naives, fato este não observado em camundongos deficientes para AIM2. De maneira interessante, quando reestimulamos as células presentes nesta cultura derivadas dos LNM, de camundongos WT e AIM2 ${ }^{-/}$diabéticos, com DNA fecal de uma microbiota normal, o número de linfócitos Th17 foi semelhante às células de camundongos WT e AIM2 ${ }^{--}$diabéticos que não receberam estímulos. Porém de forma surpreendente, quando tais células foram reestimuladas com o DNA de uma microbiota em disbiose (isolado de camundongos diabéticos) o número de linfócitos Th17 provenientes de camundongos WT diabéticos duplicou, contudo, tal efeito não foi observado em camundongos $\mathrm{AlM2}^{-/-}$diabéticos. Estes dados reforçaram a nossa hipótese que a ativação de AIM2 e consequente produção de IL-1 $\beta$ durante um processo de disbiose, poderia estar associado com aumento da expansão de linfócitos Th17, estas que por sua vez, estariam atuando na manutenção da integridade da barreira intestinal, e promovendo o controle da translocação de bactérias da microbiota para os LNP. Alguns estudos já demonstraram que em condições de disbiose, por exemplo, a produção de polissacarídeo A por Bacteroides fragilis ativa o receptor TLR2 e favorece a resposta anti-inflamatória mediada por linfócitos T reguladores (Treg), e promove 
a resposta pró-inflamatória mediada por linfócitos Th17 (ZOU; FANG; LEE, 2018).

Um fato interessante que chamou nossa atenção foi a diminuição de linfócitos Th17 em camundongos AIM2 $^{-/-}$diabéticos quando comparados com camundongos WT diabéticos. Algo semelhante foi observado por Carlos et al., (2017) em camundongos NLRP3 ${ }^{-/-}$diabéticos, que também apresentaram uma significativa diminuição de linfócitos Th17 durante o DM1. Tais dados sugerem que a diminuição de IL-1 $\beta$, seria o principal fator que leva a diminuição destas células. Contudo, a deficiência de NLRP3 em células T, além de influenciar na diferenciação de linfócitos Th2, também prejudica a diferenciação de linfócitos Th17, de forma que a células T NLRP3 ${ }^{--}$possuem uma menor diferenciação para o perfil Th17 e diminuição da expressão gênica do fator de transcrição RORC e da citocina IL-17 (BRUCHARD et al., 2015). Tais dados sugerem que estes receptores da imunidade inata possivelmente participam da diferenciação de linfócitos Th17. Isso nos levou a investigar se o receptor AIM2 também poderia atuar na diferenciação de linfócitos Th17, ou se a redução destas células observada nos LNM estaria associada apenas a baixa produção de IL-1ß. De forma surpreendente nossos resultados demonstraram que a deficiência de AIM2 em linfócitos T CD4, prejudica a diferenciação para o perfil Th17, levando à uma menor expressão gênica de RORC e IL-17, e de maneira interessante, o receptor AIM2 parece regular de forma negativa a produção de IL-22 por estas células. Tais dados enfatizam a importância do receptor AIM2 na resposta de linfócitos Th17 tanto na função de inflamassoma, através da produção de IL-1ß que atua como um fator de expansão para estas células, como em uma função independente da maquinaria do inflamassoma, atuando na diferenciação deste subtipo celular.

Baseados nestes resultados buscamos avaliar como a ativação de AIM2 estaria regulando a resposta de linfócitos Th17 na mucosa intestinal, que como previamente discutido, tem um papel importante na manutenção da integridade da barreira intestinal. Não obstante, camundongos AIM2 $2^{-/-}$diabéticos possuem uma regulação negativa da expressão de inúmeros genes relacionados à resposta de linfócitos Th17 no íleo, como por exemplo, os fatores de transcrição RORC, IRF4 e NFAT-1, assim como citocinas como IL-23, IL-1 $\beta$, IL-17 e IL-22. Também verificamos que na ausência do receptor AIM2 durante o DM1, há uma 
diminuição significativa de células T CD4 produtoras de IL-17 nos LNM, assim como baixos níveis proteicos de citocinas de perfil Th17 no íleo, como IL-23, IL$1 \beta$, IL-17 e IL-22. Estudos anteriores já demonstraram que a sinalização de citocinas derivadas da ativação de inflamassomas como a IL-1 $\beta$, por exemplo, possui um papel essencial na indução de células Th17, uma vez que o receptor de IL-1 (IL-1R) é altamente expresso em células Th17 recém diferenciadas, e sua expressão é induzida por citocinas como IL-6 e IL-23. Além disso, a citocina IL-1 $\beta$ age em sinergismo com IL-6 para induzir a expressão dos fatores de transcrição IRF4 e ROR $\gamma T$ (MAILER et al., 2015).

No que tange o papel de células Th17 no DM1, estudos apontam dados divergentes sobre o papel dessas células na patogênese do DM1. A partir dos LNP, células Th17 diferenciadas migram para o pâncreas e alteram sua plasticidade convertendo-se em células Th1, passando a expressar IFN-y e IL17, exercendo assim sua função patogênica, possivelmente através da produção de IFN-y que é altamente citotóxico para as células $\beta$ pancreáticas(MARTINOROZCO et al., 2009). Por outro lado, (KRIEGEL et al., 2011)foi demonstrado que a transmissão natural de bactérias filamentosas segmentadas em camundongos NOD (non obsese diabetic mice) protege contra 0 desenvolvimento do DM1 através do aumento de células Th17 na lâmina própria, o que sugere que a presença destas células na mucosa intestinal pode ser um mecanismo de controle do desenvolvimento da doença. Um estudo recente demonstrou que células T inatas invariantes associadas à mucosa (MAIT T cell) possuem um papel protetor na mucosa intestinal contra do desenvolvimento do DM1. Neste estudo, os autores demonstraram que a produção de IL-17A e IL-22 por células T MAIT está associada com uma redução na permeabilidade intestinal e consequente controle da translocação de bactérias da microbiota intestinal para os LNP, proporcionando proteção ao desenvolvimento do DM1 (ROUXEL et al., 2017). No entanto, há alguns pontos intrigantes no trabalho que demonstram que as células T MAIT presentes no intestino de camundongos pré-diabéticos expressam a molécula CD4, o que torna difícil de decifrar se está célula é realmente uma célula $T$ inata ou uma célula $T$ convencional, que possui a capacidade de se diferenciar em Th17. Contudo, este estudo reforça ainda mais a nossa hipótese de que citocinas do perfil Th17 tem um papel importante no controle da translocação de bactérias da microbiota intestinal para os LNP. 
De maneira geral, podemos chegar a duas possíveis conclusões quanto a função dos linfócitos Th17 mediada pela ativação de AIM2 em nosso modelo de estudo; primeiro, a ativação de AIM2 em células mieloides promove a resposta de linfócitos Th17 presentes na mucosa intestinal, que de acordo com os dados da literatura, regulam a expressão de proteínas de junção, e contribuem para a manutenção da integridade da barreira intestinal, e consequente controle da translocação de bactérias da microbiota para LNP e desenvolvimento do DM1; segundo, a expressão intrínseca de AIM2 em linfócitos T contribui para diferenciação de linfócitos Th17 nos LNP, este fato pode ser explicado devido as nossas observações, que camundongos $\mathrm{AlM}^{-1}$ - diabéticos apresentaram uma diminuição da população de linfócitos Th17 nos LNP, assim como baixos níveis de IL-17 e alto níveis de IL-1 $\beta$ no tecido pancreático quando comparado com camundongos WT diabéticos. Tais dados reforçam nossos achados, que 0 receptor AIM2 atua como um regulador positivo na diferenciação de linfócitos Th17, uma vez que na ausência do mesmo, é observada diminuição de linfócitos Th17 mesmo na presença de IL-1 $\beta$, um importante fator para a expansão destas células.

Com intuito de investigar a função das células Th17 mediada pela ativação do inflamassoma AIM2 durante 0 DM1, avaliamos 0 recrutamento/ativação de neutrófilos em camundongos WT e AIM2 $2^{-/}$diabéticos e controles na mucosa intestinal de camundongos, pois se sabe que células Th17 são importantes para o recrutamento destas células, através da indução da produção de quimiocinas como CXCL-1 e CXCL-2 por células epiteliais, macrófagos e fibroblastos (YE et al., 2001). Nossos resultados demonstraram que na deficiência do inflamassoma AIM2 há uma diminuição da população de neutrófilos nos LNM assim como baixos níveis de elastase no íleo, quando comparados com camundongos WT 7 e 15 dias após o tratamento com STZ. Contudo, não observamos diferenças na população de neutrófilos presentes nos LNP. Estudos recentes demonstram um papel benéfico dos neutrófilos na manutenção de bactérias presentes na mucosa intestinal, de forma que tal papel é atribuído a produção de lipocalina por células epiteliais, induzida pela gelatinase dos neutrófilos. A lipocalina tem um importante papel bacteriostático controlando o crescimento de bactérias como E. coli no modelo de peritonite (MORI et al., 2016). Tais dados sugerem a importância da ativação do receptor 
AIM2 na resposta de linfócitos Th17, que por sua vez modulam o recrutamento de neutrófilos a fim de manter a homeostase intestinal.

Por fim, o ultimo objetivo do nosso estudo foi compreender os mecanismos pelos quais a deficiência de AIM2 estaria associada à suscetibilidade ao DM1. Até o momento, observamos que camundongos AIM2-diabéticos possuem alterações na barreira intestinal que pode estar associada à dimuição de linfócitos Th17, e de citocinas como IL-18 e IL-22, o que contribui para uma maior translocação de bactérias da microbiota para os LNP. Como já mencionado acima, camundongos deficientes para AIM2 diabéticos apresentam altos níveis de glicose, aumento no infiltrado inflamatório nas ilhotas pancreáticas, assim como baixa produção de insulina, quando comparados ao WT diabéticos. Estes fatores que atuam na manutenção da suscetibilidade ao DM1 possivelmente ocorrem devido a translocação de bactérias da microbiota para os LNP de camundongos $\mathrm{AIM}^{-\%}$, gerando uma resposta pró-inflamatória contra as células $\beta$ pancreáticas, resultando em sua destruição. Devido a este fato, buscamos compreender quais células estariam envolvidas na suscetibilidade ao DM1 na ausência de AIM2. Além de linfócitos Th17, os linfócitos Th1 e T CD8, possuem uma função crucial na destruição das células $\beta$ pancreáticas. Nossos resultados demonstraram que a deficiência de AIM2 durante o DM1 está associada com um significativo aumento da porcentagem e número de absoluto de linfócitos T CD8 produtores de IFN- $\gamma$ (Tc1) nos LNP, assim como um aumento da porcentagem de linfócitos Th1 nos LNPs. Não obstante, camundongos AIM2 ${ }^{-/}$diabéticos apresentaram elevados níveis de IL12 p70 e IFN- $\gamma$ no tecido pancreático em relação aos camundongos WT diabéticos. Tais dados explicam a elevada suscetibilidade ao DM1 em camundongos $\mathrm{AlM}^{-1}$. Posteriormente, quando avaliado o mecanismo pelo qual células Tc1 estavam aumentadas nos LNPs de camundongos AIM2 ${ }^{-/}$diabéticos, encontramos um significativo aumento de células dendríticas expressando TLR4 e TLR9 presentes nos LNPs desses animais, além de um aumento significativo da expressão gênica da molécula adaptadora My88 e da citocina IFN- $\beta$. Neste contexto (ZHANG et al., 2010), demonstraram que a ativação do receptor TLR9 leva à produção de IFN- $\alpha$ e $\beta$, estes que por sua vez contribuem para a ativação e proliferação de células T CD8 diabetogênicas. Sendo assim, é possível que na ausência do inflamassoma AIM2, onde há uma maior translocação de bactérias 
da microbiota intestinal, ocorra aumento na ativação do receptor TLR4 e TLR9, contribuindo assim para maior resposta de células T CD8 observada em camundongos $\mathrm{AlM}^{-/}$. Tal hipótese será confirmada após um novo tratamento com coquetel de antibióticos em camundongos $\mathrm{AlM}^{-/-}$, que previamente já mostramos, onde estes animais se tornam resistentes a doença. De maneira geral, nosso estudo demonstrou um papel regulador do receptor AIM2 tanto na mucosa intestinal, atuando sobre a resposta de linfócitos Th17, quanto nos linfonodos drenantes do pâncreas, onde é capaz de inibir a ação de linfócitos Tc1. 


\section{Conclusão}


Em suma, no presente trabalho demonstramos que o receptor AIM2 possui um papel protetor durante o desenvolvimento do DM1. Ao ser ativado por DNA de bactérias da microbiota em disbiose na mucosa intestinal, o receptor AIM2 forma o complexo inflamassoma, e libera IL-1 $1 \beta$ e IL-18. A IL-1 $\beta$ parece atuar aumentando a expansão de linfócitos Th17, estes que por sua vez também parecem depender da expressão intrínseca de AIM2 para se diferenciar. Já a produção de IL-18 parece regular de maneira positiva a expressão de IL-22, peptídeos antimicrobianos e mucinas. Em conjunto, estes fatores vão proporcionar uma microbiota equilibrada, manter a integridade da barreira intestinal e controlar a translocação de bactérias da microbiota para os LNPs e, consequentemente, impedir ou retardar o início do desenvolvimento do DM1.

Nosso estudo abre perspectivas futuras para a implementação de novas abordagens terapêuticas, que ao induzir a ativação local de AIM2 no intestino, seja por agonistas desse receptor, ou DNA de bactérias probióticas, auxiliem na prevenção ou controle do desenvolvimento da doença. 
7. Referências bibliográficas 
ABREU, M. T. et al. Decreased expression of Toll-like receptor-4 and MD-2 correlates with intestinal epithelial cell protection against dysregulated proinflammatory gene expression in response to bacterial lipopolysaccharide. J Immunol, v. 167, n. 3, p. 160916, Aug 12001.

AKIRA, S. Pathogen recognition by innate immunity and its signaling. Proc Jpn Acad Ser B Phys Biol Sci, v. 85, n. 4, p. 143-56, 2009.

ARRIETA, M. C.; BISTRITZ, L.; MEDDINGS, J. B. Alterations in intestinal permeability. Gut, v. 55, n. 10, p. 1512-20, Oct 2006.

ATARASHI, K.; TANOUE, T.; HONDA, K. Induction of lamina propria Th17 cells by intestinal commensal bacteria. Vaccine, v. 28, n. 50, p. 8036-8, Nov 232010.

AUJLA, S. J.; DUBIN, P. J.; KOLLS, J. K. Th17 cells and mucosal host defense. Semin Immunol, v. 19, n. 6, p. 377-82, Dec 2007.

BERESWILL, S. et al. The impact of Toll-like-receptor-9 on intestinal microbiota composition and extra-intestinal sequelae in experimental Toxoplasma gondii induced ileitis. Gut Pathog, v. 6, p. 19, 2014.

BIROS, E.; JORDAN, M. A.; BAXTER, A. G. Genes mediating environment interactions in type 1 diabetes. Rev Diabet Stud, v. 2, n. 4, p. 192-207, Winter 2005.

BISCHOFF, S. C. et al. Intestinal permeability--a new target for disease prevention and therapy. BMC Gastroenterol, v. 14, p. 189, Nov 182014.

BROZ, P.; DIXIT, V. M. Inflammasomes: mechanism of assembly, regulation and signalling. Nat Rev Immunol, v. 16, n. 7, p. 407-20, Jul 2016.

BRUCHARD, $M$. et al. The receptor NLRP3 is a transcriptional regulator of TH2 differentiation. Nat Immunol, v. 16, n. 8, p. 859-70, Aug 2015.

BRUGMAN, S. et al. Antibiotic treatment partially protects against type 1 diabetes in the Bio-Breeding diabetes-prone rat. Is the gut flora involved in the development of type 1 diabetes? Diabetologia, v. 49, n. 9, p. 2105-8, Sep 2006.

CARLOS, D. et al. Mitochondrial DNA Activates the NLRP3 Inflammasome and Predisposes to Type 1 Diabetes in Murine Model. Front Immunol, v. 8, p. 164, 2017.

CARRATU, R. et al. Altered intestinal permeability to mannitol in diabetes mellitus type I. J Pediatr Gastroenterol Nutr, v. 28, n. 3, p. 264-9, Mar 1999.

CASTANO, L.; EISENBARTH, G. S. Type-I diabetes: a chronic autoimmune disease of human, mouse, and rat. Annu Rev Immunol, v. 8, p. 647-79, 1990. 
CHEN, Y. et al. Stimulation of airway mucin gene expression by interleukin (IL)-17 through IL-6 paracrine/autocrine loop. J Biol Chem, v. 278, n. 19, p. 17036-43, May 9 2003.

COSTA, F. R. et al. Gut microbiota translocation to the pancreatic lymph nodes triggers NOD2 activation and contributes to T1D onset. J Exp Med, v. 213, n. 7, p. 1223-39, Jun 272016.

DE GOFFAU, M. C. et al. Aberrant gut microbiota composition at the onset of type 1 diabetes in young children. Diabetologia, v. 57, n. 8, p. 1569-77, Aug 2014.

DESHMUKH, H. S. et al. The microbiota regulates neutrophil homeostasis and host resistance to Escherichia coli K1 sepsis in neonatal mice. Nat Med, v. 20, n. 5, p. 52430, May 2014.

DOMBROWSKI, Y. et al. Cytosolic DNA triggers inflammasome activation in keratinocytes in psoriatic lesions. Sci TransI Med, v. 3, n. 82, p. 82ra38, May 112011.

EMAMAULLEE, J. A. et al. Inhibition of Th17 cells regulates autoimmune diabetes in NOD mice. Diabetes, v. 58, n. 6, p. 1302-11, Jun 2009.

FANG, R. et al. Type I interferon signaling regulates activation of the absent in melanoma 2 inflammasome during Streptococcus pneumoniae infection. Infect Immun, v. 82, n. 6, p. 2310-7, Jun 2014.

FERNANDES-ALNEMRI, T. et al. AIM2 activates the inflammasome and cell death in response to cytoplasmic DNA. Nature, v. 458, n. 7237, p. 509-13, Mar 262009.

GRIS, D. et al. NLRP3 plays a critical role in the development of experimental autoimmune encephalomyelitis by mediating Th1 and Th17 responses. $\mathbf{J}$ Immunol, v. 185, n. 2, p. 974-81, Jul 152010.

GUO, H.; CALLAWAY, J. B.; TING, J. P. Inflammasomes: mechanism of action, role in disease, and therapeutics. Nat Med, v. 21, n. 7, p. 677-87, Jul 2015.

HEROLD, K. C. et al. Diabetes induced with low doses of streptozotocin is mediated by V beta 8.2+ T-cells. Diabetes, v. 44, n. 3, p. 354-9, Mar 1995.

HOOPER, L. V.; LITTMAN, D. R.; MACPHERSON, A. J. Interactions between the microbiota and the immune system. Science, v. 336, n. 6086, p. 1268-73, Jun 82012.

HORWITZ, M. S. et al. Presented antigen from damaged pancreatic beta cells activates autoreactive T cells in virus-mediated autoimmune diabetes. J Clin Invest, v. 109, n. 1, p. 79-87, Jan 2002. 
$\mathrm{HU}, \mathrm{C}$. et al. NLRP3 deficiency protects from type 1 diabetes through the regulation of chemotaxis into the pancreatic islets. Proc Natl Acad Sci U S A, v. 112, n. 36, p. 1131823, Sep 82015.

HU, G. Q. et al. AIM2 contributes to the maintenance of intestinal integrity via Akt and protects against Salmonella mucosal infection. Mucosal Immunol, v. 9, n. 5, p. 1330-9, Sep 2016.

ISHIGAME, $\mathrm{H}$. et al. Differential roles of interleukin-17A and $-17 \mathrm{~F}$ in host defense against mucoepithelial bacterial infection and allergic responses. Immunity, v. 30, n. 1, p. 10819, Jan 162009.

IVANOV, II et al. The orphan nuclear receptor RORgammat directs the differentiation program of proinflammatory IL-17+ T helper cells. Cell, v. 126, n. 6, p. 1121-33, Sep 22 2006.

JIN, T. et al. Structures of the HIN domain:DNA complexes reveal ligand binding and activation mechanisms of the AIM2 inflammasome and IFI16 receptor. Immunity, v. 36, n. 4, p. 561-71, Apr 202012.

KABAROWSKI, J. $\mathrm{H}$. et al. Lysophosphatidylcholine as a ligand for the immunoregulatory receptor G2A. Science, v. 293, n. 5530, p. 702-5, Jul 272001.

KANTWERK-FUNKE, G.; BURKART, V.; KOLB, H. Low dose streptozotocin causes stimulation of the immune system and of anti-islet cytotoxicity in mice. Clin Exp Immunol, v. 86, n. 2, p. 266-70, Nov 1991.

KIMKONG, I.; AVIHINGSANON, Y.; HIRANKARN, N. Expression profile of HIN200 in leukocytes and renal biopsy of SLE patients by real-time RT-PCR. Lupus, v. 18, n. 12, p. 1066-72, Oct 2009.

KING, C.; SARVETNICK, N. The incidence of type-1 diabetes in NOD mice is modulated by restricted flora not germ-free conditions. PLoS One, v. 6, n. 2, p. e17049, Feb 25 2011.

KINUGASA, T. et al. Claudins regulate the intestinal barrier in response to immune mediators. Gastroenterology, v. 118, n. 6, p. 1001-11, Jun 2000.

KRIEGEL, M. A. et al. Naturally transmitted segmented filamentous bacteria segregate with diabetes protection in nonobese diabetic mice. Proc Natl Acad Sci U S A, v. 108, n. 28, p. 11548-53, Jul 122011.

KUGELBERG, E. Immune tolerance: A window of opportunity. Nat Rev Immunol, v. 16, n. 1, p. 4, Jan 2016.

KYOKO, O. O. et al. Expressions of tight junction proteins Occludin and Claudin-1 are under the circadian control in the mouse large intestine: implications in intestinal permeability and susceptibility to colitis. PLoS One, v. 9, n. 5, p. e98016, 2014. 
LEE, J. S. et al. Interleukin-23-Independent IL-17 Production Regulates Intestinal Epithelial Permeability. Immunity, v. 43, n. 4, p. 727-38, Oct 202015.

LEHUEN, A. et al. Immune cell crosstalk in type 1 diabetes. Nat Rev Immunol, v. 10, n. 7, p. 501-13, Jul 2010.

LEY, R. E. et al. Obesity alters gut microbial ecology. Proc Natl Acad Sci U S A, v. 102, n. 31, p. 11070-5, Aug 22005.

MAILER, R. K. et al. IL-1beta promotes Th17 differentiation by inducing alternative splicing of FOXP3. Sci Rep, v. 5, p. 14674, Oct 62015.

MARTIN-OROZCO, N. et al. Th17 cells promote pancreatic inflammation but only induce diabetes efficiently in lymphopenic hosts after conversion into Th1 cells. Eur J Immunol, v. 39, n. 1, p. 216-24, Jan 2009.

MATHIS, D.; VENCE, L.; BENOIST, C. beta-Cell death during progression to diabetes. Nature, v. 414, n. 6865, p. 792-8, Dec 132001.

MAXWELL, J. R. et al. Differential Roles for Interleukin-23 and Interleukin-17 in Intestinal Immunoregulation. Immunity, v. 43, n. 4, p. 739-50, Oct 202015.

MENSAH-BROWN, E. P. et al. IL-23 leads to diabetes induction after subdiabetogenic treatment with multiple low doses of streptozotocin. Eur J Immunol, v. 36, n. 1, p. 21623, Jan 2006.

MORDES, J. P. et al. Rat models of type 1 diabetes: genetics, environment, and autoimmunity. ILAR J, v. 45, n. 3, p. 278-91, 2004.

MORI, K. et al. Neutrophil gelatinase-associated lipocalin regulates gut microbiota of mice. J Gastroenterol Hepatol, v. 31, n. 1, p. 145-54, Jan 2016.

MULLANEY, J. A. et al. Type 1 diabetes susceptibility alleles are associated with distinct alterations in the gut microbiota. Microbiome, v. 6, n. 1, p. 35, Feb 172018.

NEU, J. et al. Changes in intestinal morphology and permeability in the biobreeding rat before the onset of type 1 diabetes. J Pediatr Gastroenterol Nutr, v. 40, n. 5, p. 58995, May 2005.

PATTERSON, C. C. et al. Incidence trends for childhood type 1 diabetes in Europe during 1989-2003 and predicted new cases 2005-20: a multicentre prospective registration study. Lancet, v. 373, n. 9680, p. 2027-33, Jun 132009.

PATTERSON, E. et al. Streptozotocin-induced type-1-diabetes disease onset in Sprague-Dawley rats is associated with an altered intestinal microbiota composition and decreased diversity. Microbiology, v. 161, n. Pt 1, p. 182-93, Jan 2015. 
PELASEYED, T. et al. The mucus and mucins of the goblet cells and enterocytes provide the first defense line of the gastrointestinal tract and interact with the immune system. Immunol Rev, v. 260, n. 1, p. 8-20, Jul 2014.

POIROT, L.; BENOIST, C.; MATHIS, D. Natural killer cells distinguish innocuous and destructive forms of pancreatic islet autoimmunity. Proc Natl Acad Sci U S A, v. 101, n. 21, p. 8102-7, May 252004.

PONTILLO, A. et al. Two SNPs in NLRP3 gene are involved in the predisposition to type-1 diabetes and celiac disease in a pediatric population from northeast Brazil. Autoimmunity, v. 43, n. 8, p. 583-9, Dec 2010.

PORITZ, L. S. et al. Loss of the tight junction protein ZO-1 in dextran sulfate sodium induced colitis. J Surg Res, v. 140, n. 1, p. 12-9, Jun 12007.

RATHINAM, V. A. et al. The AIM2 inflammasome is essential for host defense against cytosolic bacteria and DNA viruses. Nat Immunol, v. 11, n. 5, p. 395-402, May 2010.

RATSIMANDRESY, R. A. et al. The AIM2 inflammasome is a central regulator of intestinal homeostasis through the IL-18/IL-22/STAT3 pathway. Cell Mol Immunol, v. 14, n. 1, p. 127-142, Jan 2017.

REDONDO, M. J. et al. Concordance for islet autoimmunity among monozygotic twins. N Engl J Med, v. 359, n. 26, p. 2849-50, Dec 252008.

REWERS, $M$. et al. Trends in the prevalence and incidence of diabetes: insulindependent diabetes mellitus in childhood. World Health Stat Q, v. 41, n. 3-4, p. 179-89, 1988.

ROUXEL, O. et al. Cytotoxic and regulatory roles of mucosal-associated invariant $\mathrm{T}$ cells in type 1 diabetes. Nat Immunol, v. 18, n. 12, p. 1321-1331, Dec 2017.

SAI, P.; RIVEREAU, A. S. Prevention of diabetes in the nonobese diabetic mouse by oral immunological treatments. Comparative efficiency of human insulin and two bacterial antigens, lipopolysacharide from Escherichia coli and glycoprotein extract from Klebsiella pneumoniae. Diabetes Metab, v. 22, n. 5, p. 341-8, Oct 1996.

SAXENA, A. et al. Tc17 CD8+ T cells potentiate Th1-mediated autoimmune diabetes in a mouse model. J Immunol, v. 189, n. 6, p. 3140-9, Sep 152012.

SUZUKI, T. Regulation of intestinal epithelial permeability by tight junctions. Cell Mol Life Sci, v. 70, n. 4, p. 631-59, Feb 2013.

SZEBENI, A. et al. Th1 and Th2 cell responses of type 1 diabetes patients and healthy controls to human heat-shock protein 60 peptides AA437-460 and AA394-408. Inflamm Res, v. 54, n. 10, p. 415-9, Oct 2005. 
UNO, S. et al. Macrophages and dendritic cells infiltrating islets with or without beta cells produce tumour necrosis factor-alpha in patients with recent-onset type 1 diabetes. Diabetologia, v. 50, n. 3, p. 596-601, Mar 2007.

WOJKOWSKA, D. W. et al. Interactions between neutrophils, Th17 cells, and chemokines during the initiation of experimental model of multiple sclerosis. Mediators Inflamm, v. 2014, p. 590409, 2014.

WOOD, S. C.; RAO, T. D.; FREY, A. B. Multidose streptozotocin induction of diabetes in $B A L B / c B y$ mice induces a $T$ cell proliferation defect in thymocytes which is reversible by interleukin-4. Cell Immunol, v. 192, n. 1, p. 1-12, Feb 251999.

YAOCHITE, J. N. et al. Dynamic changes of the Th17/Tc17 and regulatory $\mathrm{T}$ cell populations interfere in the experimental autoimmune diabetes pathogenesis. Immunobiology, v. 218, n. 3, p. 338-52, Mar 2013.

YE, P. et al. Requirement of interleukin 17 receptor signaling for lung CXC chemokine and granulocyte colony-stimulating factor expression, neutrophil recruitment, and host defense. J Exp Med, v. 194, n. 4, p. 519-27, Aug 202001.

YI, Z. et al. IFN-gamma receptor deficiency prevents diabetes induction by diabetogenic CD4+, but not CD8+, T cells. Eur J Immunol, v. 42, n. 8, p. 2010-8, Aug 2012.

YUAN, Q.; WALKER, W. A. Innate immunity of the gut: mucosal defense in health and disease. J Pediatr Gastroenterol Nutr, v. 38, n. 5, p. 463-73, May 2004.

ZEISSIG, S. et al. Changes in expression and distribution of claudin 2, 5 and 8 lead to discontinuous tight junctions and barrier dysfunction in active Crohn's disease. Gut, v. 56 , n. 1, p. 61-72, Jan 2007.

ZHANG, Y. et al. TLR9 blockade inhibits activation of diabetogenic CD8+ T cells and delays autoimmune diabetes. J Immunol, v. 184, n. 10, p. 5645-53, May 152010.

ZOU, S.; FANG, L.; LEE, M. H. Dysbiosis of gut microbiota in promoting the development of colorectal cancer. Gastroenterol Rep (Oxf), v. 6, n. 1, p. 1-12, Feb 2018.

ZURAWEK, M. et al. A coding variant in NLRP1 is associated with autoimmune Addison's disease. Hum Immunol, v. 71, n. 5, p. 530-4, May 2010. 
8. Anexos 
ANEXO I- Artigo de revisão publicado durante o mestrado.

ANEXO II - Certificado recebido da Sociedade Brasileira de Imunologia (SBI) pela melhor apresentação de pôster na categoria Mestrado (SBI Scientific Award 2017 - Best pôster of Master Student) durante O XLI Congress of Brazilian Society of Immunology - (Mucosal Immuno - 2017) em Salvador - BA.

ANEXO III- Menção honrosa recebida pela comissão organizadora do I Simpósio de Imunologia Básica e Aplicada (I SIBA 2017) pela 2ª melhor apresentação oral - Categoria: Mestrado.

ANEXO IV - Certificado de aprovação do projeto de pesquisa em comitê de ética em pesquisa animal da Faculdade de Medicina de Ribeirão Preto/ USP (CONCEA). 


\title{
ANEXO I
}

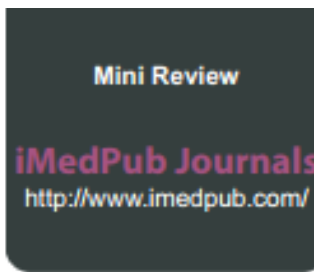

\section{NLRP3 Inflammasome: From Pathogenesis to Therapeutic Strategies in Type 1 Diabetes}

\author{
Daniela Carlos ${ }^{1 *}$, Frederico RC Costa ${ }^{1}$, Jefferson A Leite ${ }^{1}$, Camila A André ${ }^{2}$, Rita C Tostes ${ }^{2}$, Fernando S \\ Carneiro $^{2}$, Niels OS Camara ${ }^{3}$ and Joăo S Silva ${ }^{1}$ \\ ${ }^{1}$ Department of Biochemistry and Immunology, Ribeirao Preto Medical School, University of São Paulo, Ribeirão Preto, São Paulo, Brazil \\ ${ }^{2}$ Department of Pharmacology, Ribeirao Preto Medical School, University of São Paulo, Ribeirđ̃o Preto, São Paulo, Brazil \\ SDepartment of Immunology, Institute of Biomedical Sciences (ICB), University of São Paulo, São Paulo, Brazil
}

"Corresponding author: Daniela Carlos, Department of Biochemistry and Immunology, Ribeirao Preto Medical School, University of Sāo Paulo, Ribeirão Preto, Ș̄o Paulo, Brazil, Tel: +55-16-3315-3234; E-mail: danicar@usp.br

Received date: May 25, 2017; Accepted date: June 15, 2017; Published date: June 20, 2017

Citation: Carlos D, Costa FRC, Leite IA, André CA, Tostes RC, et al. (2017) NLRP3 Inflammasome: From Pathogenesis to Therapeutic Strategies in Type 1 Diabetes. I Autoimmune Disord Vol 3 iss 2: 30.

Copyright: 2017 Carlos D, et al. This is an open-access article distributed under the terms of the Creative Commons Attribution License, which permits unrestricted use, distribution, and reproduction in any medium, provided the original author and source are credited.

\section{Abstract}

Type 1 diabetes mellitus (T1DM) is an autoimmune disease characterized by a T-cell-mediated destruction of the pancreatic $\beta$ cells. Several environmental factors have been proposed as candidate triggers for T1DM, considering that a genetic predisposition alone is not sufficient to explain the increasing incidence rates over the past decades. This organ-specific autoimmune disease is the consequence of multifactorial processes involving dysregulation of the innate and adaptive damage insulin-producing $\beta$ cells. In this review, we reported the contribution of innate immune receptors in modulating the pathogenic lymphocyte responses in T1DM development, with a particular emphasis to NLRP3, which can be considered as a potential therapeutic target to treat T1DM

Keywords: Diabetes mellitus; Insulin; Immune response

\section{Introduction}

Type 1 diabetes mellitus (T1DM) is an autoimmune disease in which the insulin-producing pancreatic $\beta$ cells are damaged by the immune system. The incidence of T1DM is increasing at fast rates in many developed countries. The sharp rise can be explained by a complex interaction between genetic susceptibility and environmental factors [1]. Therefore, several environmental factors, such as viral infections, food products and gut microbiota have been proposed as potential triggers of the disease $[2,3]$.

There are several lines of evidence demonstrating that T1DM can be triggered by viral infection, which can cause direct $\beta$ cell death and apoptosis as a result of local inflammation, molecular mimicry or cross reactivity with viral epitopes [4]. Although several viral infections have been implicated in the progression of T1DM, particular enteroviruses have been isolated from patients newly diagnosed with the disease. In human T1DM, increased TLR3 expression occurs in mononuclear cells that infiltrate pancreatic islets [5]. It was suggested that innate responses induced by enterovirus are sensed by TLR3, promote inflammatory pathway activation and result in $\beta$ cell destruction. However, deficiency of TLR3 does not interfere in spontaneous T1DM development in the non-obese diabetic (NOD) mouse [6]. Conversely, TLR3 plays a fundamental role in virus-induced T1DM in NOD and C57BL/6 mice [7,8]. Additionally, TLR7 signaling induced by viral RNA or synthetic ligand can initiate pathogenic lymphocyte activation and precipitate diabetes in NOD mice $[9,10]$

In addition to viral products, endogenous ligands, released after the process of death or cellular damage, may also activate the innate immune system and drive the adaptive immune response in T1DM. This hypothesis is reinforced by the occurrence of marked $B$ cell apoptosis prior to the onset of the insulitis process in NOD mice, with subsequent conversion into cells exhibiting necrotic signals [11]. Thus, delayed clearance and subsequent accumulation of apoptotic cells appears to be one of the inducing mechanisms of T1DM. In fact, apoptotic cells undergoing secondary necrosis are able to activate antigen presenting cells (APCs), which in turn stimulate pathogenic T lymphocytes through a TLR2-dependent mechanism in T1DM [12]. Accordingly, higher expression of high mobility group box 1 (HMGB1), an inflammatory endogenous trigger, was found in the cytoplasm of islet cells in diabetic NOD mice compared with non-diabetic mice [13]. HMGB1 may act through TLR4 and directly damage $\beta$ cells during T1DM progression. In addition, the use of monoclonal antibody to TLR4/MD-2 (TLR4-Ab) reversed genetically-induced T1DM in NOD mice, by a mechanism dependent on induction of tolerogenic APCs and expansion of regulatory T cells (Tregs) in both the periphery and the pancreatic islets [14]. In contrast, TLR4-deficient mice crossed with NOD mice (TLR4/NOD) develop accelerated T1DM compared to wild-type NOD mice $[15,16]$. 


\section{ANEXO II}

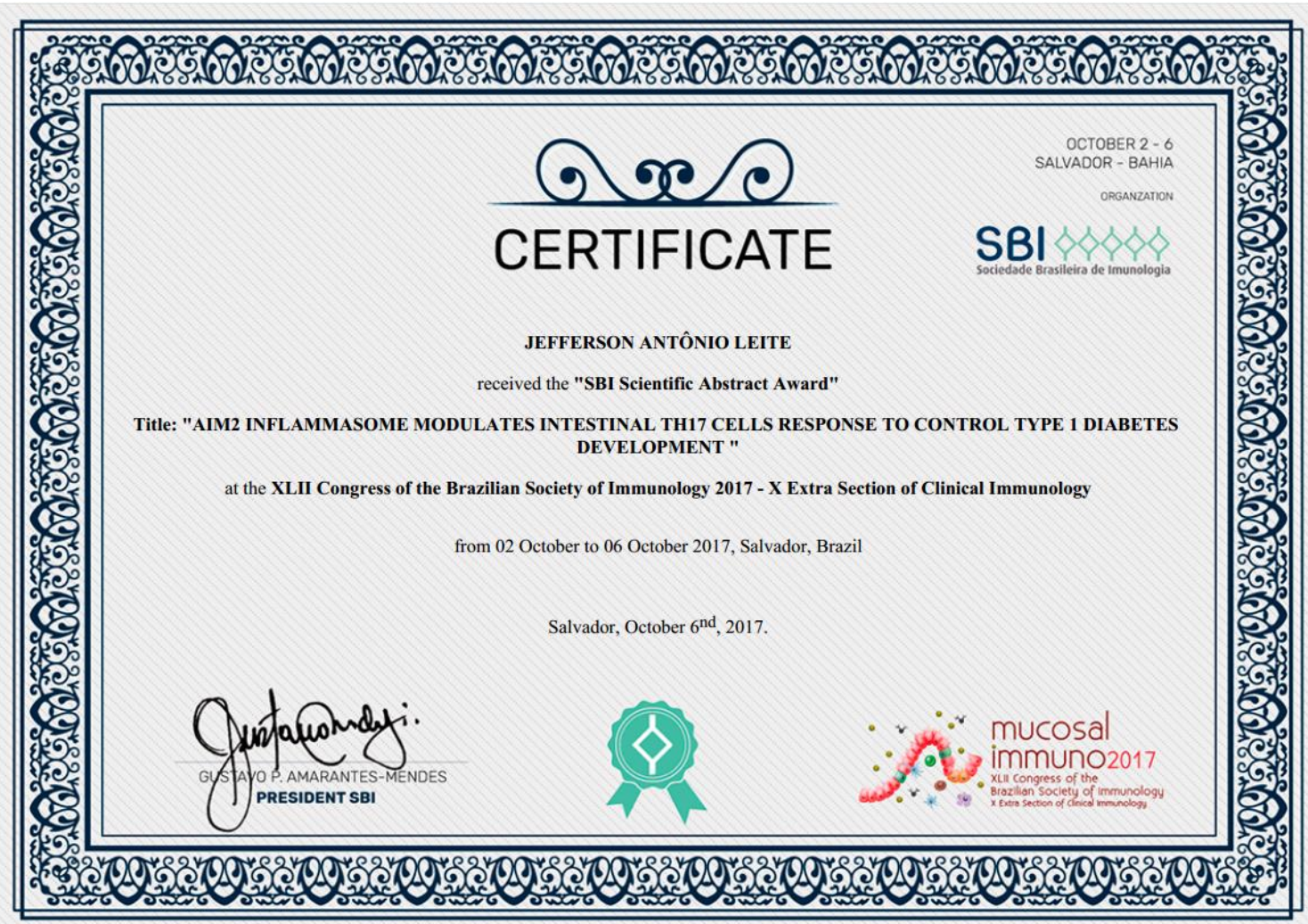




\section{ANEXO III}

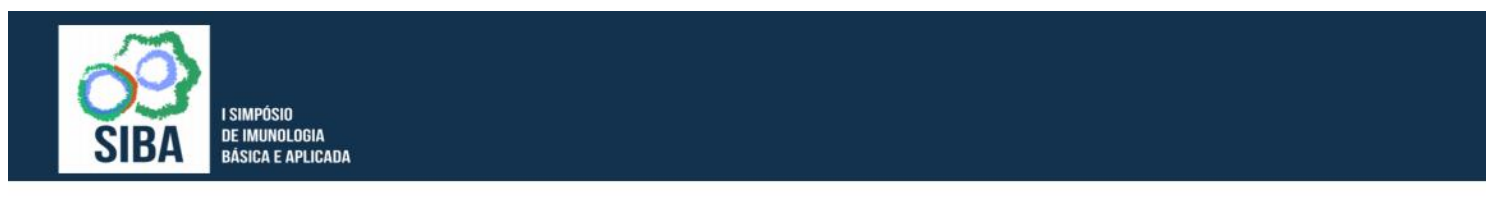

\section{CERTIFICADO}

O programa de Imunologia Básica e Aplicada da Faculdade de Medicina de Ribeirão Preto certifica que

\section{Jefferson A. Leite}

Recebeu Menção Honrosa (Segundo lugar) na categoria apresentação oral, modalidade Mestrado, com o trabalho intitulado

\section{"ATIVAÇÃO DO INFLAMASSOMA AIM2 NA MUCOSA INTESTINAL CONTRIBUI PARA A} RESISTÊNCIA AO DIABETES TIPO 1 EXPERIMENTAL"

I Simpósio de Imunologia Básica e Aplicada (I SIBA), 2017 Ribeirão Preto-SP, 20 a 21 de julho de 2017. 


\section{ANEXO IV}
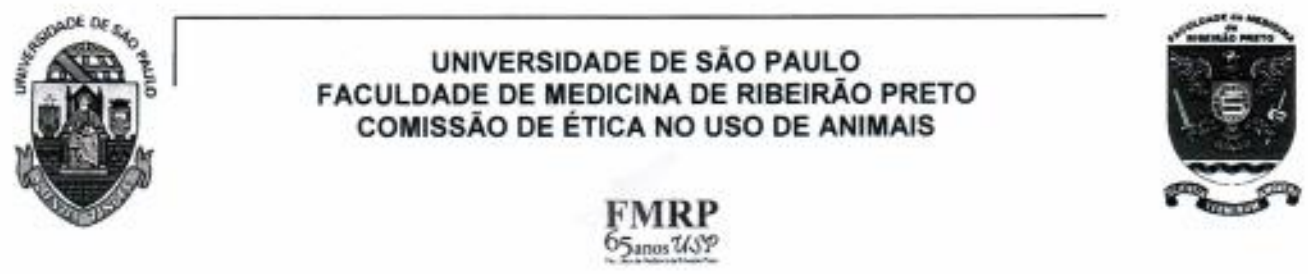

\section{CER TIF I CA D O}

Certificamos que o Protocolo intitulado "Avaliação do perfil de expressão e função do inflamassoma AIM2 na mucosa intestinal durante o diabetes tipo l experimental", registrado com o número 215/2016, sob a responsabilidade do Prof. Dr. João Santana da Silva, envolvendo a produção, manutenção ou utilização de animais pertencentes ao filo Chordata, subfilo Vertebrata (exceto humanos) para fins de pesquisa cientifica, encontra-se de acordo com os preceitos da Lei $n^{\circ} 11.794$ de 8 de outubro de 2008, do Decreto $n^{\circ} 6.899$ de 15 de julho de 2009 e com as normas editadas pelo Conselho Nacional de Controle de Experimentaçã̀o Animal (CONCEA), e foi APROVADO pela Comissão de Ética no Uso de Animais da Faculdade de Medicina de Ribeirão Preto da Universidade de São Paulo em reunião de 24 de abril de 2017.

Este Protocolo prevê a utilização de 80 camundongos $\mathrm{C} 57 \mathrm{Bl} / 6$ machos pesando $26 \mathrm{~g}$ oriundos do Serviço de Biotério da Prefeitura do Campus de Ribeirão Preto da Universidade de São Paulo, 80 camundongos AIM2 KO machos e 60 camundongos IL-18 KO machos ambos pesando 26g oriundos do Biotério de Imunologia da Faculdade de Medicina de Ribeirão Preto da Universidade de São Paulo. Vigência da autorização: 24/04/2017 a 01/07/2018.

We certify that the Protocol $n^{*} 215 / 2016$, entitled "Evaluation of profile expression and function of AIM2 inflammesome in the gut mucosal during experimental npe 1 diabetes", is in accordance with the Ethical Principles in Animal Research adopted by the National Council for the Control of Animal Experimentation (CONCEA) and was approved by the Local Animal Ethical Committee from Ribeirato Preto Medical School of the University of Såo Paulo in $04 / 24 / 2017$. This protocol involves the production, maintenance or use of animals from phylum Chordata, subphylum Vertebrata (except humans) for research purposes, and includes the use of 80 male C57BV/6 mice weighing 26g from the Central Animal House of Ribeirão Preto Medical School, University of Sao Paulo, 80 male AIM2 KO mice and 60 male IL-18 KO mice weighing $26 \mathrm{~g}$ from the Immunology Animal House of Ribeirào Preto Medical School, University of São Paulo. This certificate is valid until 07/01/2018.

Ribeirāo Preto, 24 de abril de 2017 